\title{
15. CLIMATIC CHANGES IN THE WESTERN SAHARA: AEOLO-MARINE SEDIMENT RECORD OF THE LAST 8 MILLION YEARS (SITES 657-661) ${ }^{1}$
}

\author{
Ralf Tiedemann, ${ }^{2}$ Michael Sarnthein, ${ }^{2}$ and Ruediger Stein ${ }^{3}$
}

\begin{abstract}
Five Ocean Drilling Program sites (657-661), which form a north-south transect off the western periphery of the Sahara, were selected to measure the long-term history of Saharan/Sahelian dust flux and fluvial sediment discharge and the fluxes of marine $\mathrm{CaCO}_{3}$ and opal over the last $8 \mathrm{~m}$.y. Sites 658 and 659 served for high-resolution studies, and Sites 657, 660, and 661 for insights into the spatial patterns of dust flux. The nearshore mean flux of opal off Cap Blanc $\left(21^{\circ} \mathrm{N}\right)$ showed an abrupt increase about $3 \mathrm{Ma}$ that appears to reflect the main onset of coastal upwelling fertility and enhanced trade winds. At the same time, the input of river-borne clay strongly decreased, suggesting a dry up of the central Saharan rivers. Later, marked short-lived spikes of clay and opal may indicate ongoing ephemeral pulses of fluvial runoff linked to peak interglacial stages.

Given the zonal dust discharge centered near $18^{\circ} \mathrm{N}$ at Site 659 , the aridification of the south Sahara and Sahel increased in several steps: at 4.6, 4.3, and especially at 4.0,3.6, and 2.1 Ma, and again, at $0.8 \mathrm{Ma}$. The late Miocene and earliest Pliocene were humid. Although the central and north Saharan climate appears to be linked to the glaciation history of the Northern Hemisphere, the long-term aridification further south followed a different schedule. The spatial distribution of quartz accumulation suggests that the dust outbreaks linked to the Intertropical Convergence Zone during summer did not shift in latitude back to $4.0 \mathrm{Ma}$, at least. The short-term variations of dust output over the last $0.5 \mathrm{~m} . \mathrm{y}$. followed orbital scale pulses with a strong precessional signal, showing a link of Sahelian humidity changes to the variation of sea-surface temperature and evaporation in the tropical Atlantic.
\end{abstract}

\section{INTRODUCTION}

One of the pressing questions in paleoclimatology concerns the history, fluctuations, and origin of continental aridity in North Africa. Changes in the climate of the south Sahara and Sahel Zones are linked to a number of meteorological factors (Tetzlaff and Peters, 1986), such as (1) the moisture balance along the Intertropical Convergence Zone (ITCZ) controlled by sea-surface temperatures and evaporation in the Gulf of Guinea and the equatorial Indian Ocean; (2) the north-south gradient in surface temperature from the Sahara to the Gulf of Guinea; (3) the related intensities and directions of major surface and mid-tropospheric wind tracks; and (4) the latitudinal position of the ITCZ during northern summer (e.g., Nicholson and Flohn, 1980).

As shown in a number of articles (e.g., Sarnthein and Koopmann, 1980; Sarnthein et al., 1982; Stein, 1984, 1985a; Robert and Chamley, 1986), the deep-sea sediment record from the Atlantic Ocean offshore from West Africa reveals basic insights into the evolution of land climate and the variability of the outlined meteorological patterns. A new step in stratigraphic quality is reached by the almost complete late Miocene to Quaternary sections of pelagic and hemipelagic sediments that were recovered from the northwest African continental margin, $10^{\circ}-21^{\circ} \mathrm{N}$ at Sites 657-661, during Leg 108 of the Ocean Drilling Program (ODP) with double and triple coring techniques (i.e., advanced hydraulic piston corer [APC] and extended core barrel corer [XCB]; Fig. 1, Table 1; Ruddiman, Sarnthein, et al., 1988). High sedimentation rates at Sites $658(7-25 \mathrm{~cm} / \mathrm{k} . \mathrm{y}$.) and 659 (about $3 \mathrm{~cm} / \mathrm{k} . \mathrm{y}$. back to

\footnotetext{
'Ruddiman, W., Sarnthein, M., et al., 1989. Proc. ODP, Sci. Results, 108: College Station, TX (Ocean Drilling Program).

${ }^{2}$ Geologisch-Paläontologisches Institut, Universität Kiel, D-2300 Kiel, Olshausenstrasse 40, Federal Republic of Germany.

${ }^{3}$ Institut für Geowissenschaften und Lithosphärenforschung, Universität Giessen, Senckenbergstrasse 3, D-6300 Giessen, Federal Republic of Germany.
}

4.6 Ma) provide a special opportunity for detailed paleoclimatic studies.

This study examines the lithogenic and opal fractions in these new sediment sections. One major objective is to trace the long-term trends in Saharan aridification and to compare them with the various steps of Northern Hemisphere glaciation (Sarnthein and Tiedemann, this vol.). In particular, we try to date the possible onset of continental aridity during the late Neogene and to identify other main climatic changes that may be important for the evolution of African man. A second objective is to depict some short-term trends in west Saharan paleoclimate and paleometeorology through visual description of sediment records and comparison with the oxygen isotope record of global ice-volume history.

Off West Africa, the lithogenic (siliciclastic) sediment accumulation is controlled by three major sources. The first source, aeolian dust supply, dominates the modern deposition at all five sites (657-661). The main transport of dust occurs in the Saharan Air Layer (SAL) (Carlson and Prospero, 1977) coupled to the zonal mid-tropospheric African Easterly Jet (AEJ) between 1000 and $5000 \mathrm{~m}$ height. These dust outbreaks follow the temperature gradient linked to the ITCZ, which today attains its northernmost position near $18^{\circ} \mathrm{N}$ during northern summer. Additional dust is supplied by the northeasterly trade winds near the surface below $1000 \mathrm{~m}$ height (Fig. 1; Tetzlaff and Wolter, 1980; Sarnthein and Koopmann, 1980; Sarnthein et al., 1982; Stein and Sarnthein, 1984).

The second lithogenic sediment source, fluvial sediments, can be expected at Site 658 only, on the continental slope off Cap Blanc during more humid climate phases such as 6000-9000 yr ago (cf. Sarnthein, 1978; Sarnthein and Koopmann, 1980; Stein, 1985a; Street and Grove, 1979). Turbidites, the third clastic sediment source, only contribute to the sediment balance of Site 657 and were studied in detail by Faugères et al. (this vol.).

In this paper, we will deduce proxy data from an inspection of siliciclastic sediments on a number of different paleocli- 


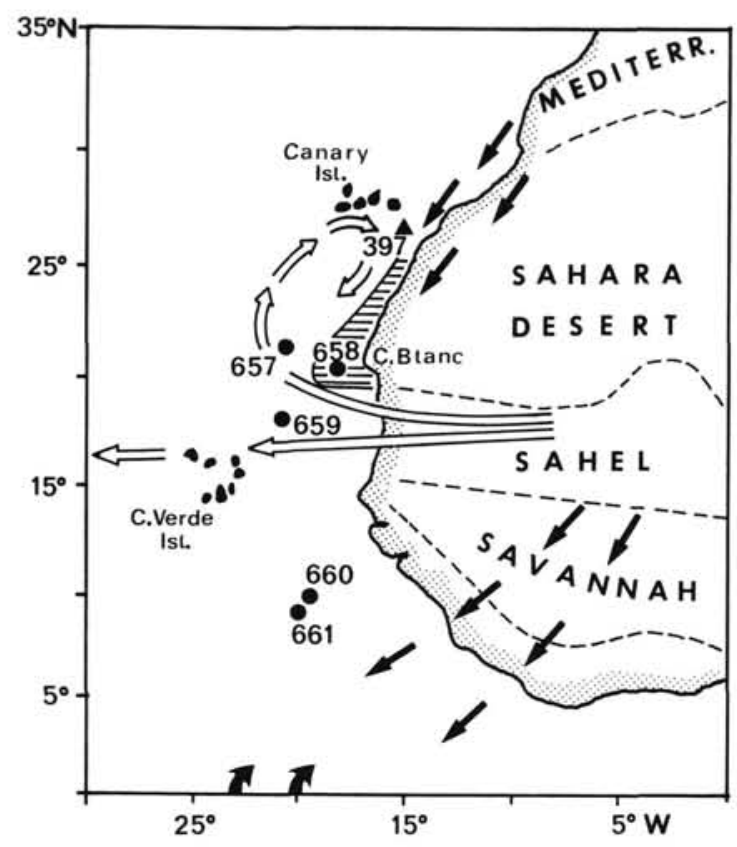

Figure 1. Location map of ODP Sites 657-661 and DSDP Site 397 with a schematic presentation of major climatic zones in Africa. Arrows mark flow patterns of dust supply by different wind regimes. Solid arrows indicate meridional trade winds; open arrows, mid-tropospheric zonal winds of Saharan Air Layer/African Easterly Jet; and hachured areas, perennial coastal upwelling (modified from Stein and Sarnthein, 1984).

Table 1. Location of Sites 657-661 and 397.

\begin{tabular}{ccc}
\hline Site & Position & $\begin{array}{c}\text { Water } \\
\text { depth } \\
(\mathrm{m})\end{array}$ \\
\hline Site 657 & $21^{\circ} 20^{\prime} \mathrm{N}, 20^{\circ} 57^{\prime} \mathrm{W}$ & 4226 \\
Site 658 & $20^{\circ} 45^{\prime} \mathrm{N}, 18^{\circ} 35^{\prime} \mathrm{W}$ & 2263 \\
Site 659 & $18^{\circ} 05^{\prime} \mathrm{N}, 21^{\circ} 02^{\prime} \mathrm{W}$ & 3070 \\
Site 660 & $10^{\circ} 01^{\prime} \mathrm{N}, 19^{\circ} 14^{\prime} \mathrm{W}$ & 4328 \\
Site 661 & $9^{\circ} 27^{\prime} \mathrm{N}, 19^{\circ} 23^{\prime} \mathrm{W}$ & 4006 \\
Site 397 & $26^{\circ} 51^{\prime} \mathrm{N}, 15^{\circ} 11^{\prime} \mathrm{W}$ & 2900 \\
\hline
\end{tabular}

matic and paleometeorologic variables, which include the following:

1. The rates of dust flux and accumulation are reduced by precipitation scavenging the atmosphere (Brazel, 1986) and by humid vegetation cover in the source region (Hooghiemstra et al., 1986); these rates generally reflect the degree of continental aridity (Prospero, 1985; Prospero and Nees, 1986; Middleton, 1985; Pye, 1987), although not necessarily in linear terms (Pye, in press).

2. The bulk dust mineralogy indicates the long-term heritage of weathering conditions of a source area (Kolla et al., 1979; Chamley, 1979; Sarnthein, 1979; Stein, 1985a, 1986; Stein and Robert, 1985).

3. Phases of marked humidity are inferred from clay-rich fluvial sediment deposition off central western Sahara, which occasionally may be accompanied by events of immense nearshore biogenic opal production triggered by river-borne fertilization (Pokras and Molfino, 1986). At Site 658, these events overlap the persistently high biogenic opal production characteristic of the local perennial upwelling cell at $21^{\circ} \mathrm{N}$ (see below).
Table 2. Sampling resolution at Sites 658, 659, and 660 .

\begin{tabular}{|c|c|c|c|c|}
\hline Site & Components & $\begin{array}{l}\text { Time } \\
\text { interval } \\
\text { (in } \mathrm{Ma} \text { ) }\end{array}$ & $\begin{array}{l}\text { Time } \\
\text { resolution } \\
\text { (in yr) }\end{array}$ & $\begin{array}{c}\text { Average } \\
\text { sample } \\
\text { distance } \\
\text { (in } \mathrm{m} \text { ) }\end{array}$ \\
\hline \multirow[t]{12}{*}{658} & \multirow[t]{4}{*}{$\delta^{18} \mathrm{O}$} & $0-0.73$ & 2400 & 0.36 \\
\hline & & $1.56-2.0$ & 6100 & 0.65 \\
\hline & & $2.0-2.5$ & 8600 & 0.59 \\
\hline & & $2.5-3.55$ & 6000 & 0.67 \\
\hline & \multirow[t]{4}{*}{ Siliciclastic } & $0-0.73$ & 3000 & 0.45 \\
\hline & & $1.56-2.0$ & 4000 & 0.38 \\
\hline & & $2.0-2.5$ & 5000 & 0.40 \\
\hline & & $2.5-3.6$ & 3500 & 0.42 \\
\hline & \multirow[t]{2}{*}{ Opal } & $0-0.73$ & 9000 & 1.34 \\
\hline & & $1.56-3.6$ & 16200 & 1.70 \\
\hline & \multirow{2}{*}{$\begin{array}{l}\text { Clay, silt }>6 \mu \mathrm{m}, \\
\text { modal grain size }\end{array}$} & $0-0.73$ & $9800-10100$ & $1.45-1.50$ \\
\hline & & $1.5-3.55$ & $25100-29800$ & $2.56-3.04$ \\
\hline \multirow[t]{4}{*}{659} & $\delta^{18} \mathrm{O}$ & $0-1.0$ & 9200 & 0.30 \\
\hline & \multirow[t]{3}{*}{ Siliciclastic } & $0-1.0$ & 7400 & 0.24 \\
\hline & & $1.0-4.0$ & 12000 & 0.35 \\
\hline & & $4.0-8.0$ & 26300 & 0.39 \\
\hline \multirow[t]{2}{*}{660} & \multirow[t]{2}{*}{ Siliciclastic } & $0-4.0$ & 39600 & 0.72 \\
\hline & & $4.0-7.0$ & Low & 1.00 \\
\hline
\end{tabular}

4. The summer position of the ITCZ can be traced along with the center of (essentially carbonate-free) Saharan dust outbreaks from the AEJ (Carlson and Prospero, 1977; Sarnthein and Koopmann, 1980; Sarnthein et al., 1982).

5 . Wind directions are manifested by the clay and bulk mineral composition (Kolla et al., 1979; Leinen and Heath, 1981; Sarnthein et al., 1982; Lange, 1982) and the pollen and diatom load of dust (Hooghiemstra et al., 1986, 1987; cf. Dupont et al., this vol., and Stabell, this vol.).

5. Fluctuations in wind speed can be estimated from variations in the grain-size distribution of silt (Sarnthein et al., 1981; Rea and Janacek, 1982).

In many respects, the present report on continental paleoclimates is still preliminary. The sampling resolution for most parameters is inadequate to resolve fully the "genuine" short-term climatic variations attributed to variations in the earth's orbit (e.g., 23 and 41 k.y.; Table 2). Furthermore, only few data can be compared from sections with an adequate oxygen isotope stratigraphy (Site 658 and topmost Site 659).

\section{METHODS}

Carbonate contents were determined by infrared absorption of $\mathrm{CO}_{2}$ released with phosphoric acid with a CHN Analyzer in Giessen and a Beckmann Infrared Analyzer in Kiel. Further shipboard values, which were based on a Carbonate Bomb (Müller and Gastner, 1971) and a Coulometrics Carbon Dioxide Coulometer (Ruddiman, Sarnthein, et al., 1988), were included in the data set, since the deviation of measurements obtained by different techniques is small $( \pm 3 \%)$.

The organic carbon content was measured directly on the carbonate-free residue of the samples with a LECO Analyzer (Kiel). Shipboard values derived by calculating the difference between total carbon (Perkin Elmer 240 Elemental Analyzer) and inorganic carbon (Ruddiman, Sarnthein, et al., 1988) were also included. Deviations between data from different techniques increase from about $3 \%$ at concentrations of $>1 \%$ up to $10 \%$ at concentrations $<0.5 \%$ (Tiedemann, 1985). This data set will be presented, in part, by Stein et al. (this vol.).

The proportion of the carbonate-free clay fraction was determined by means of the Atterberg separation method (details in Müller, 1967) at samples from key positions on the oxygen isotope curve. The biogenic opal content of the carbonate-free $2-63 \mu$ m sediment fraction was determined by the density separation technique of Bohrmann (1986). However, we replaced bromoform and dimethylforamid with potassium polywolframate as the heavy liquid solution. 


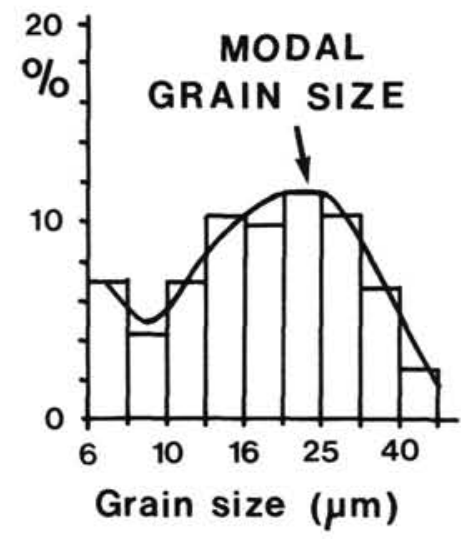

Figure 2. Graphic method to obtain the modal grain size (main peak of integrated frequency histograph area). The siliciclastic silt $>6 \mu \mathrm{m}$ is classified into subfractions of 0.1 zeta $^{\circ}\left(=0.32\right.$ phi $\left.^{\circ}\right)$ units.

Grain-size distributions of the carbonate- and opal-free sediment fraction 2-63 $\mu \mathrm{m}$ were analyzed with a SediGraph instrument as described by Stein (1985b). The modal grain size of the 6.3-63 $\mu \mathrm{m}$ fraction was obtained from the frequency maximum in histographs, where the grain-size classes were presented as subfractions of 0.1 zeta $^{\circ}\left(=0.32\right.$ phi $\left.^{\circ}\right)$ intervals and the peak area of the grain size classes was integrated (Fig. 2). The deviation is about 0.05 zeta $^{\circ}$.

A useful tool to distinguish between aeolian and fluvial sediment supply, at least for sediments offshore from northwest Africa, is the relationship between the modal grain size of siliciclastic silt and the percentage of siliciclastic (carbonate- and opal-free) silt $>6 \mu \mathrm{m}$ in the bulk siliciclastic sediment fraction (Fig. 3; Koopmann, 1981). Three sediment groups are distinguished in Figure 3: Group I = samples with well-sorted, wind-borne material; Group II = samples showing a relative excess in clay-sized lithogenic sediment caused by fluvial clay discharge; and Group III = samples indicating a relative deficit in clay that may be a result of local winnowing.

In Figures $3 \mathrm{~A}-3 \mathrm{C}$, the bounding lines for Group I above are based on modern sediment data by Coulter Counter of Koopmann (1981) and calibrated with the modern sediment input regime. The lines have been modified for SediGraph data according to Stein (1984). We are aware of the problem that the bounding lines cannot strictly separate the different sediment origins in a continuous mixing system. The sample population in Group I is considered to contain a dominant fluvial component with a broad spectrum of eolian dust quantities admixed. Most samples in Group II, however, will contain eolian dust only, since already a minor fluvial admixture will form a dominant overprint by excess clay. Accordingly, the separation scheme of Figures $3 \mathrm{~A}-3 \mathrm{C}$ has proven to be a reliable tracer of the different sediment sources in numerous cases (Koopmann, 1981; Sarnthein et al., 1982; Stein, 1985a; Sirocko and Sarnthein, in press).

All bulk mineralogy data were obtained from X-ray diffraction (XRD) measurements performed on powder slides with the shipboard Philips ADP 3520 instrument and the IGL Siemens D500 instrument. Test measurements performed on a set of samples with both instruments have shown that the data derived from the two instruments are comparable. The bulk mineralogy is mostly dominated by quartz and/or calcite, as shown in Appendixes A-E. Thus, the quartz percentages can be calculated by correlating the geochemically determined calcium-carbonate percent values (Cook et al., 1975) with the joint quartz $(3.34 \AA)$ and calcite $(3.03 \AA) \mathrm{X}$-ray intensity values as follows:

$$
\frac{X q}{X c}=k \frac{I q}{I c}
$$

or

$$
X q=k \frac{I q X c}{I c}
$$

where $X q$ = weight percent of quartz,

$X c=$ weight percent of calcite,

$I q=$ XRD intensity of quartz,

$I c=\mathrm{XRD}$ intensity of calcite, and

$k=1.45$ (constant for Philips instrument) or

1.76 (constant for Siemens instrument).

The constant $k$, an intensity factor, depends on the instrument geometry and the mass attenuation coefficients of the minerals; it has been determined from quartz/calcite-standard mixtures $(1-1)$ for both XRD instruments.

Mass accumulation rates were calculated according to van Andel et al. (1975):

$$
\text { MAR }[\text { component }]=\operatorname{LSR}(\mathrm{WBD}-1.026 \mathrm{PO}) \frac{X}{10},
$$

or

$$
\operatorname{MAR}[\text { component }]=\operatorname{LSR} \mathrm{DBD} \frac{X}{10}
$$

where MAR $=$ mass accumulation rate $\left(\mathrm{g} \mathrm{m}^{-2} \mathrm{yr}^{-1}\right)$,

LSR $=$ linear sedimentation rate $\left(\mathrm{cm} 1000 \mathrm{yr}^{-1}\right)$,

WBD $=$ wet-bulk density $\left(\mathrm{g} \mathrm{cm}^{-3}\right)$,

$\mathrm{PO}=$ porosity $(\% / 100)$,

$X=$ sediment component (wt $\%$ ), and

$\mathrm{DBD}=$ dry-bulk density $\left(\mathrm{g} \mathrm{cm}^{-3}\right.$ wet volume $)$

Dry-bulk density values at Site 658 were determined by drying and weighing a defined volume of the wet samples immediately after their arrival at the Kiel laboratory. In samples from Site 659, which were stored in plastic vials refrigerated at $8^{\circ} \mathrm{C}$ for almost $1 \mathrm{yr}$, the water contents were so reduced in comparison with shipboard data that we had to discard them and interpolate from shipboard data. Wet-bulk density, porosity, and further dry density values were determined on board by using a Penta Pycnometer and a Gamma Ray Attenuation Porosity Evaluator (GRAPE; shipboard data from Ruddiman, Sarnthein, et al., 1988). No correction factor was applied to correct for possible systematic deviations between GRAPE bulk densities and Kiel laboratory values (as suggested by Ruddiman and Janacek, this vol.).

Mean sedimentation rates for estimating accumulation rates were calculated for all sites from magnetic and biostratigraphic ages (Fig. 4) presented by the Shipboard Scientific Party (Ruddiman, Sarnthein, et al., 1988). At Sites 658 and 659, new and revised biostratigraphic datums from Chepstow-Lusty et al. (this vol.) and further magnetostratigraphic datums from Tauxe et al. (this vol.) were included. Oxygen isotope stratigraphy from Site 658 and the topmost section of 659 (Sarnthein and Tiedemann, this vol.) served as the age control for reconstructing more detailed sedimentation rates on a high-resolution scale during the last 3.4 and $1.0 \mathrm{~m} . y$., respectively.

The isotope-stage chronology was obtained from Imbrie et al. (1984), Raymo et al. (in press), and Ruddiman et al. (1986) back to 2.75 $\mathrm{Ma}$ and extended back to $3.4 \mathrm{Ma}$ by Sarnthein and Tiedemann (this vol.).

Bulk accumulation rates were calculated for Holes $657 \mathrm{~A}$ and $661 \mathrm{~A}$ from nominal sub-bottom depths and at Sites 658, 659, and 660 from composite depth values in order to combine the records from the A-C holes (Ruddiman, Sarnthein, et al., 1988; Sarnthein and Tiedemann, this vol.).

With the use of accumulation rates, we can exclude mutual dilution effects by different components. Hence, it is possible to interpret the data in terms of absolute changes in the supply or flux of carbonate, biogenic opal, siliciclastics, quartz, and feldspar/clays, respectively. However, high-frequency variations in accumulation rates can only be regarded as real where a tuned $\delta^{18} \mathrm{O}$ stratigraphy is available (i.e., at Site 658 for the last $2.4 \mathrm{~m} . \mathrm{y}$. and at Site 659 for the last $1 \mathrm{~m} . \mathrm{y}$.). In the remaining sections, the sedimentation rates may be "aliased" by the linear interpolation between distant magneto- and biostratigraphic age control points.

The siliciclastic accumulation rates are estimated by subtracting the accumulation rates of carbonate, organic carbon, and biogenic 

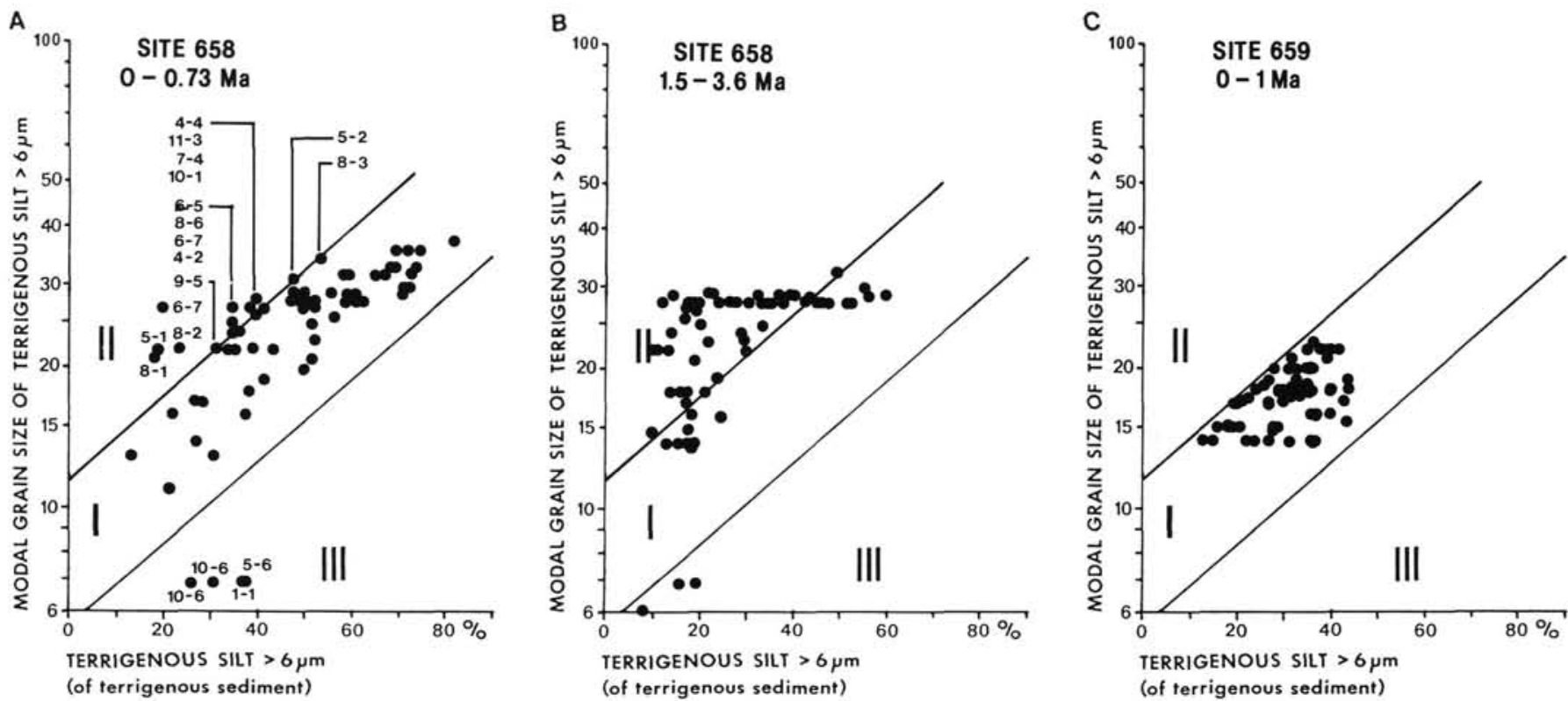

Figure 3. Proportions of the siliciclastic silt fraction $>6 \mu \mathrm{m}$ vs. modal grain size of siliciclastic silt at Site $658(\mathbf{A}=$ last $0.73 \mathrm{~m} . \mathrm{y}$. and $\mathbf{B}=1.5-3.6$ m.y.) and Site $659(\mathrm{C}=$ last $1 \mathrm{~m} . \mathrm{y}$.$) . Group I = well-sorted grain sizes characteristic of aeolian dust; Group II = sediments with relative excess$ of river-borne clay; and Group III = sediments with a relative deficit of clay, indicating sediment winnowing on the seafloor (according to Koopmann, 1981).

opal from the bulk accumulation rates. The accumulation rates of feldspar/clay are calculated as the bulk accumulation minus the quartz and carbonate accumulation. This approach seems to be legitimate because components other than quartz, calcite, feldspars, and clay minerals are generally negligible. Site 658 (Fig. 6) forms an exception, where higher amounts of biogenic opal (Mienert et al., 1988 ) and organic carbon also have to be considered. Biogenic opal was determined for approximately every second sample, particularly at key levels in the oxygen isotope and the dry-bulk density records (Appendixes A-E). Intervening opal contents were derived from linear interpolation.

The percentages and accumulation rates of carbonate, quartz, and feldspar plus clay for Sites 657-661 are presented in Figure 5. Concentrations and accumulation rates of biogenic opal are presented only for Site 658 (Fig. 6). Siliciclastic accumulation rates are shown for Sites 658, 659, and 660 in Figures 7-9. Figure 7 also displays the percentages of the clay fraction $<2 \mu \mathrm{m}$ and silt fraction $>6 \mu \mathrm{m}$ at Site 658 and the distribution of (river-related) samples with a relative excess in abundance of clay (cf. Fig. 3). Percentages of carbonate, opal, and the main siliciclastic grain-size fractions are summarized in Appendixes A-E. Note that the sampling resolution is different for the various sites and variables (Table 2).

\section{RESULTS}

Site 658 is located on the continental slope (Fig. 1) where the sediments are expected to monitor the nearshore dust deposition mainly supplied by northerly trades and the occasional input of fluvial mud supplied by central Saharan rivers at $21^{\circ} \mathrm{N}$ through the last 3.6 m.y. Sediments at Sites 657 and 659-661 lie far from any possible fluvial sediment discharge (Ruddiman, Sarnthein, et al., 1988). Those at Site 659 record strictly the input of AEJ supplied dust in the center of the present-day Saharan dust outbreaks. This pattern has remained centered at essentially the same latitude through the present interglacial and last glacial times (Sarnthein et al., 1981 ) and, hence, is expected to have persisted there through the Quaternary and late Neogene, as discussed below. Site 657 lies at the northern margin of the AEJ dust outbreaks. Sites 660 and 661 obtain dust sediments from the southern margin of AEJ-borne dust outbreaks as well as from northeasterly trades during winter.

Based on the prevailing nannofossil ooze cycles, the dust record at Site 657 on the lower continental rise is fairly undisturbed from lateral hemipelagic sediment supply along the seafloor, except for a number of turbidites and sediment slumps that can be distinguished quantitatively (see below). The position of Site 658 at the protrusion of the continental slope between two major canyon systems and below a terrace at the slope promises minimum disturbance of the hemipelagic sediment record by lateral downslope transport of shallowwater sediments (Ruddiman, Sarnthein, et al., 1988). Sites 659-661 were located on top and on the rise of submarine plateaus that lie off from the continental margin and are likely to exclude any significant downslope supply of terrigenous sediments near the seafloor.

\section{Site 657}

The two late Miocene samples at Site 657 (Fig. 5) are characterized by low carbonate contents $(10 \%$ and $30 \%)$ and quartz contents of about $30 \%$. Above the hiatus at $4.6-6.0 \mathrm{Ma}$ (i.e., in the Pliocene to lower Pleistocene), carbonate values are high, most of them ranging between 55\% and $85 \%$. Quartz contents are low, ranging between $5 \%$ and $20 \%$ (Fig. 5A). The sample with a very low carbonate content of $20 \%$ and a high quartz content of $30 \%$ at about $3.3 \mathrm{Ma}$ is part of a turbidite horizon (Faugères et al., this vol.). During the last $1 \mathrm{~m} . \mathrm{y}$., carbonate values vary between $25 \%$ and $80 \%$. Quartz shows maximum values of up to $60 \%$ near $0.75 \mathrm{Ma}$ and decreases during the last $0.5 \mathrm{Ma}$ to values between $5 \%$ and $30 \%$. The sediments of the slump interval near 0.7 Ma display carbonate values between $30 \%$ and $50 \%$ and quartz values between $15 \%$ and $60 \%$ (Fig. $5 \mathrm{~A}$ ).

Apart from two major mud flows and/or slumps, the hemipelagic sedimentation rates at Site 657 are somewhat aliased by frequent turbidite layers (Ruddiman, Sarnthein, et 


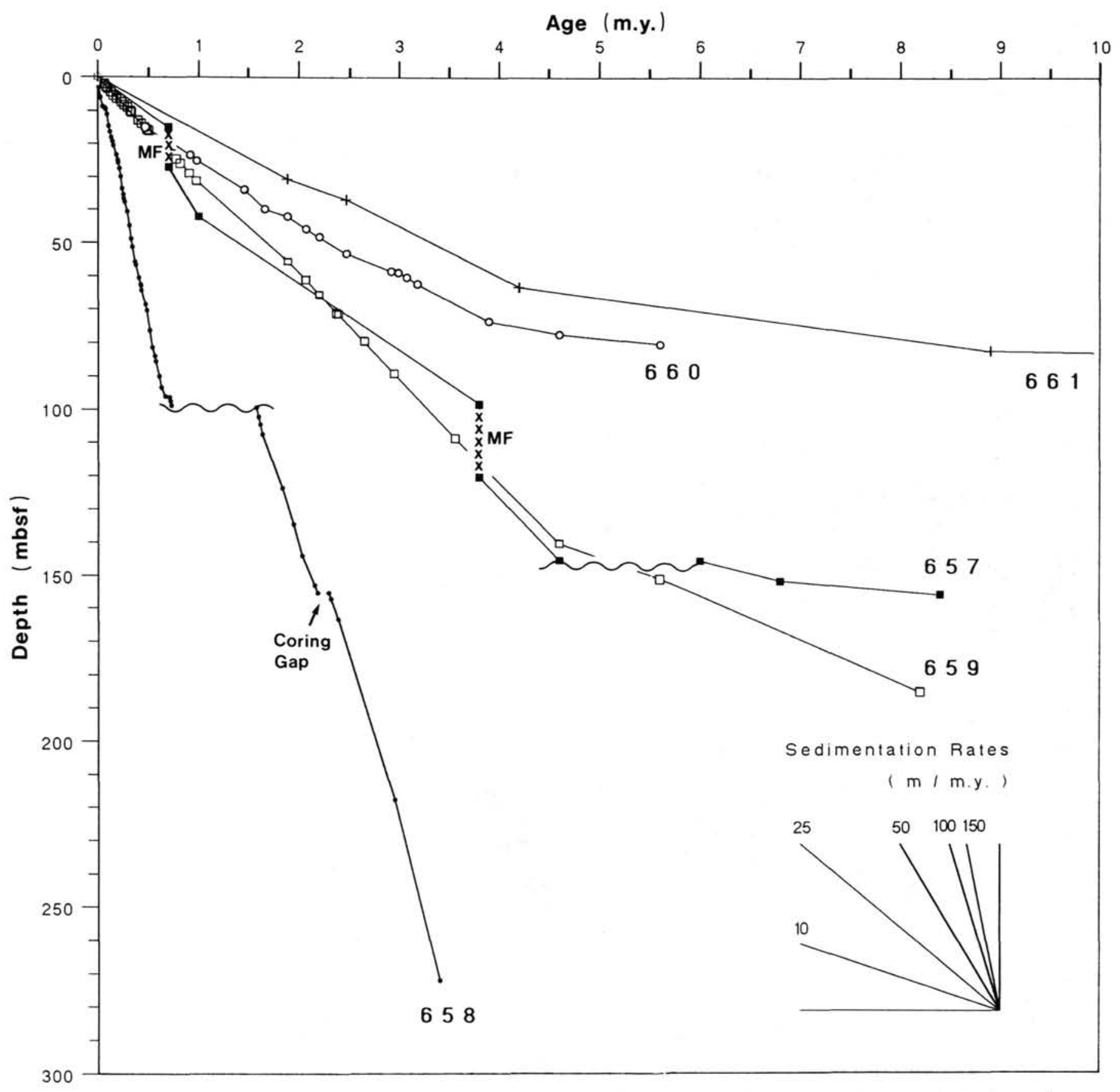

Figure 4. Sedimentation rate curves for Sites 657, 658, 659, 660, and 661 (modified from Ruddiman, Sarnthein, et al., 1988). Oxygen isotope stratigraphy is considered for curves of Sites 658 and 659 (Sarnthein and Tiedemann, this vol.). Wavy lines indicate hiatuses.

al., 1988; Faugères et al., this vol.). Most of these layers, however, do not exceed $1-5 \mathrm{~cm}$ thickness, with only a few of them reaching up to $80 \mathrm{~cm}$. Based on Site 657 shipboard data, we summed up the total turbidite thickness. The numbers demonstrate that the proportions of bulk sedimentation rates that originate from the turbidites are small (Table 3). They range from $6 \%$ to $8 \%$ during the last $1 \mathrm{~m} . \mathrm{y}$. and between $0 \%$ and $1.5 \%$ from 1 to $4 \mathrm{Ma}$, except for an isolated maximum of $19.3 \%$ at 2.5-3.0 Ma. These percentages must be subtracted from the following accumulation rate figures in order to arrive at real rates of hemipelagic sedimentation (cf. Fig. 12).

The accumulation rates of quartz and of feldspar plus clay (2.0-7.0 $\left.\mathrm{g} \mathrm{m}^{-2} \mathrm{yr}^{-1}\right)$ were continuously low from 6.5 to $1 \mathrm{Ma}$, except for a few single spikes with higher values of $2-15 \mathrm{~g} \mathrm{~m}^{-2}$ $\mathrm{yr}^{-1}$ at $6.5-3.8 \mathrm{Ma}$, and no significant changes can be observed during the late Pliocene. The last $1 \mathrm{~m}$.y. was characterized by high-amplitude variations of quartz and feldspar plus clay accumulation rates between 1 and $20 \mathrm{~g} \mathrm{~m}^{-2} \mathrm{yr}^{-1}$, with the highest values occurring between 1 and $0.7 \mathrm{Ma}$ (Fig. 5A).

\section{Site 658}

Sedimentation rates at Site 658 (Fig. 4) are higher by a factor of 5 to 10 than at any one of the four pelagic sites (657, $659,660$, and 661$)$. Bulk accumulation rates reach $80-260 \mathrm{~g}$ 
A

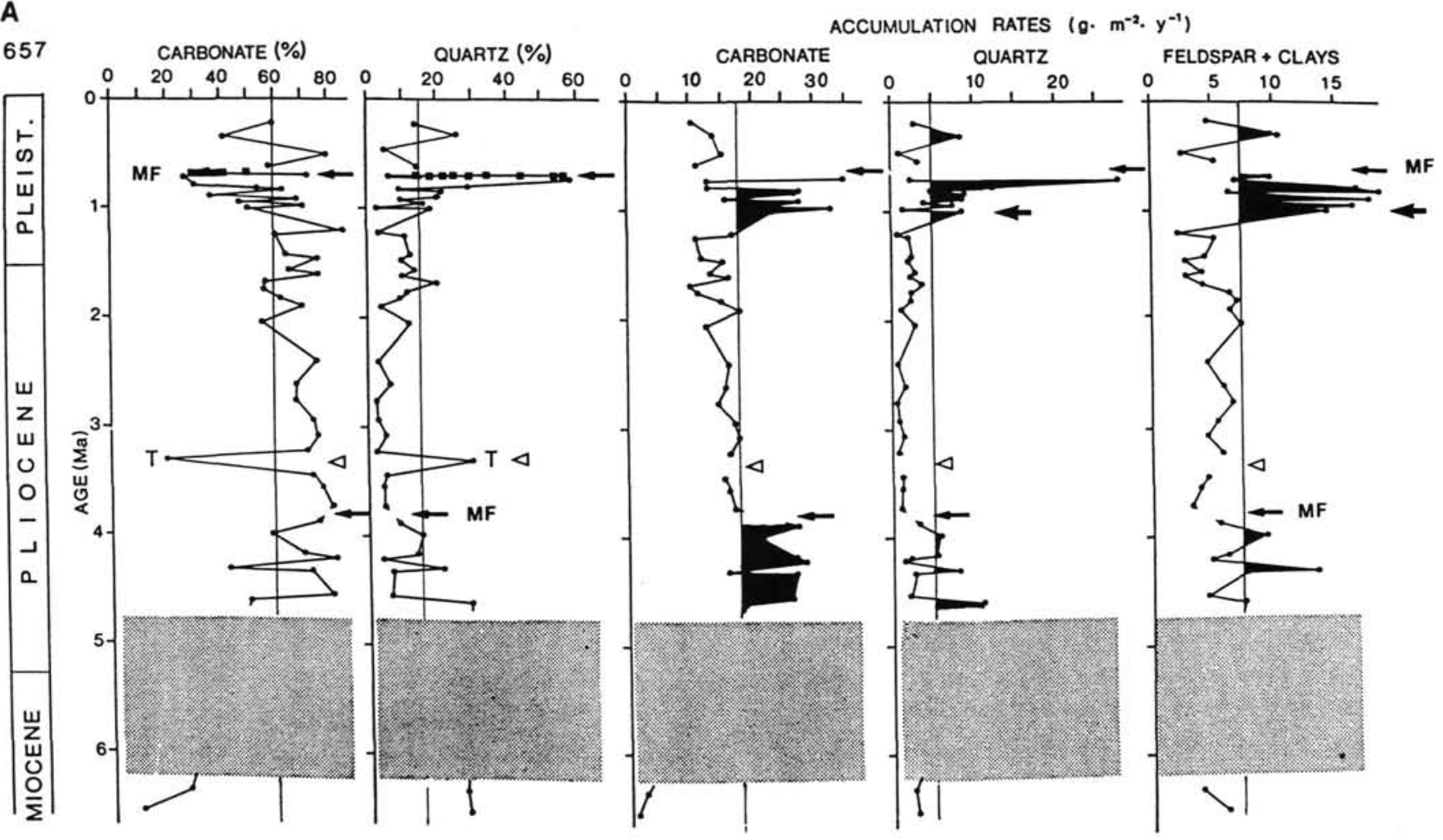

B

658
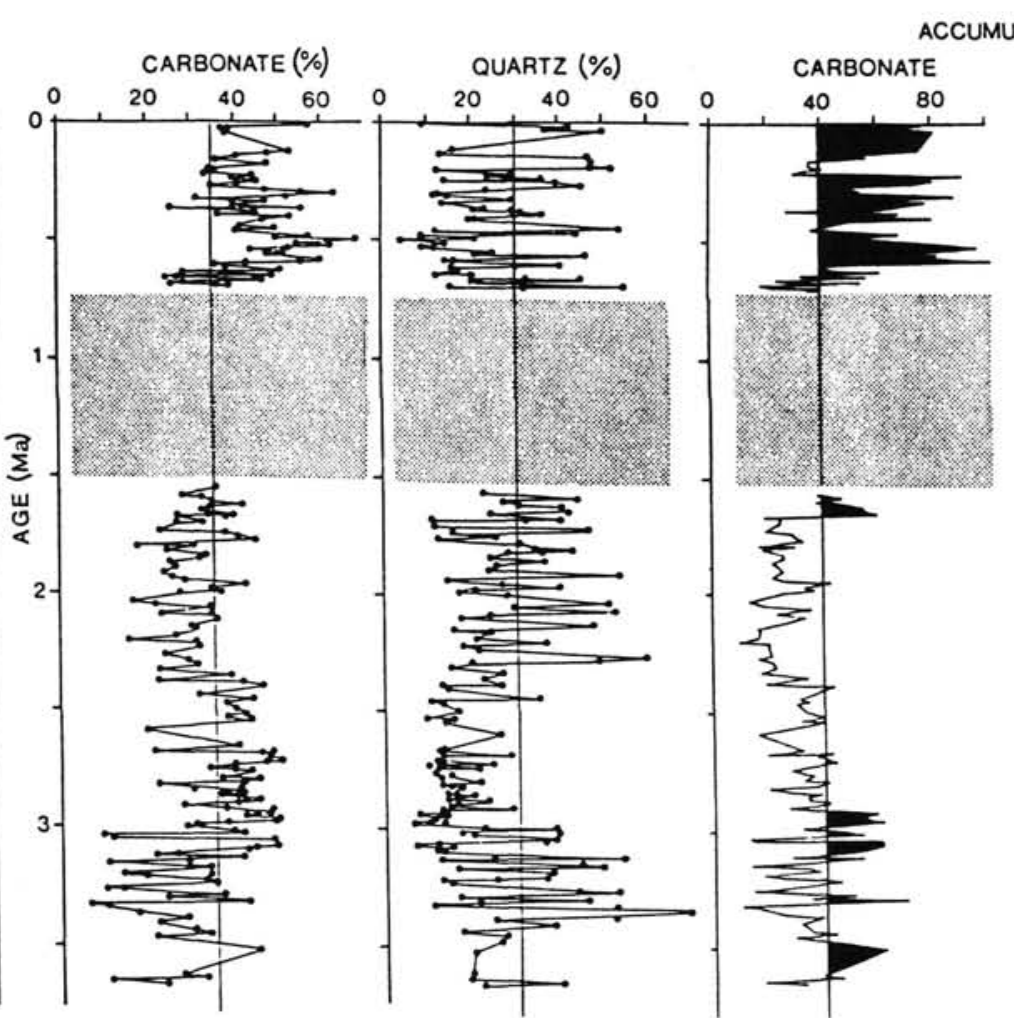

MULATION RATES $\left(g \cdot \mathrm{m}^{-2} \cdot \mathrm{y}^{-1}\right)$
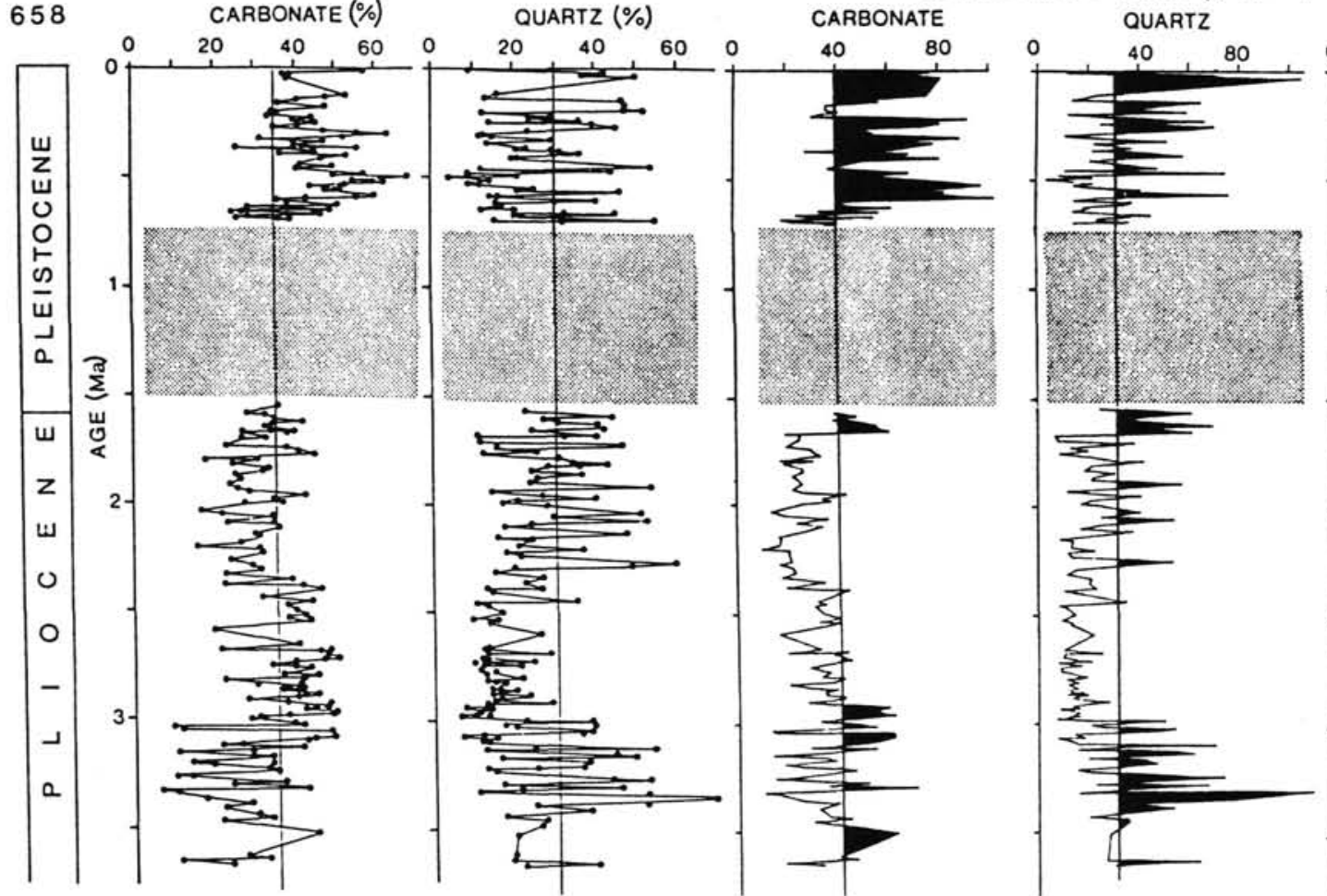

FELDSPAR + CLAYS (+ OPAL)

Figure 5. Percentages of carbonate and quartz, and mass accumulation rates of carbonate, quartz, and feldspar/clay for Sites 657-661 (A-E). Shaded intervals indicate stratigraphic gaps. Solid arrows at Site 657 mark mud flows (MF), and open triangles indicate turbidites. Bulk accumulation rates include data from minor turbidites at Site 657 , but no data from mud flows. Note that the stratigraphy of Site 658 is uncorrected for a recently found coring gap at about 2.3 Ma (Sarnthein and Tiedemann, this vol.). 
C

659

CARBONATE (\%)

QUARTZ (\%)

ACCUMULATION RATES $\left(g \cdot m^{-2} \cdot y^{-1}\right)$
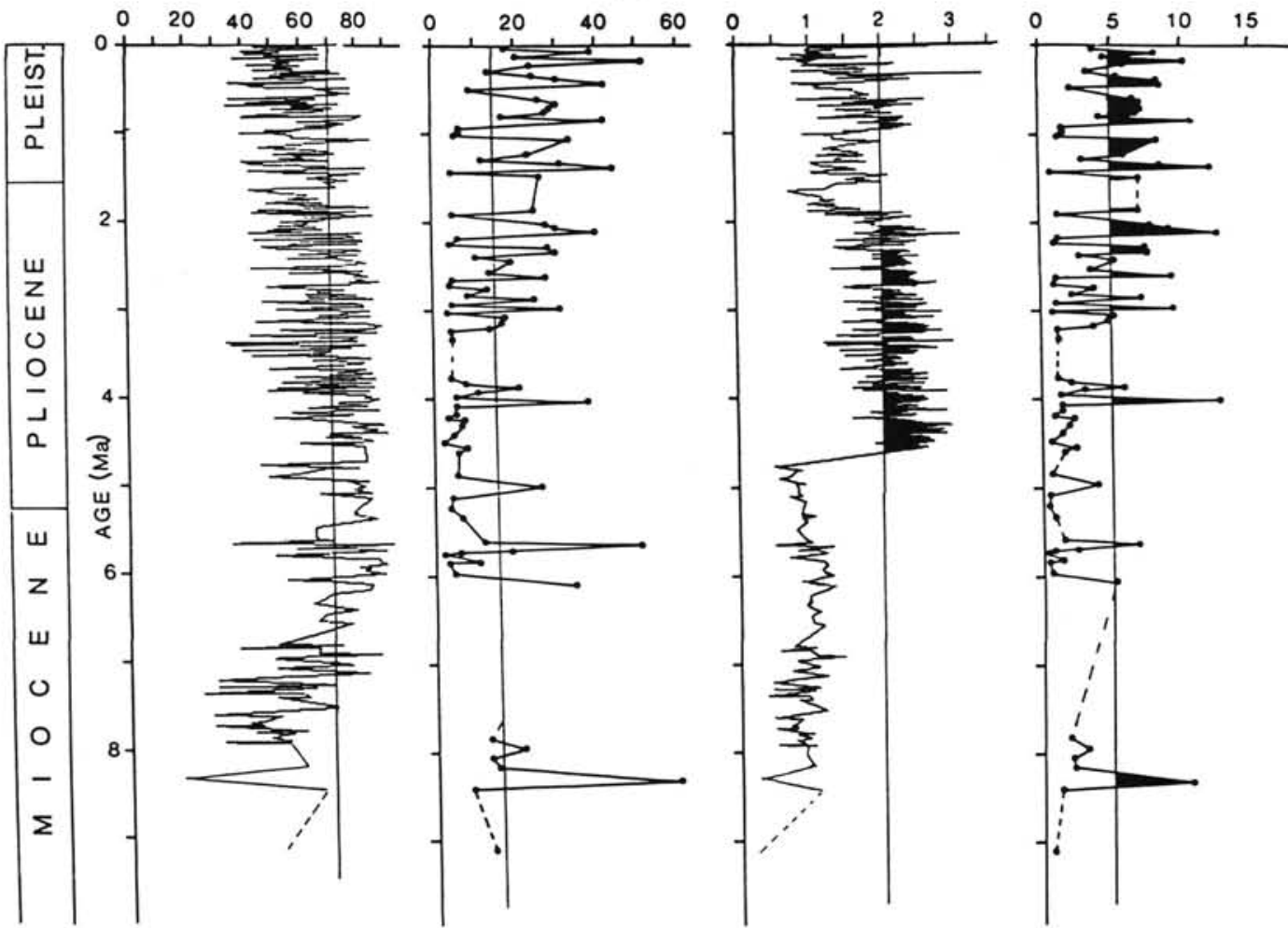

FELDSPAR + CLAYS

D

ACCUMULATION RATES $\left(g \cdot \mathrm{m}^{-2} \cdot \mathrm{y}^{-1}\right)$

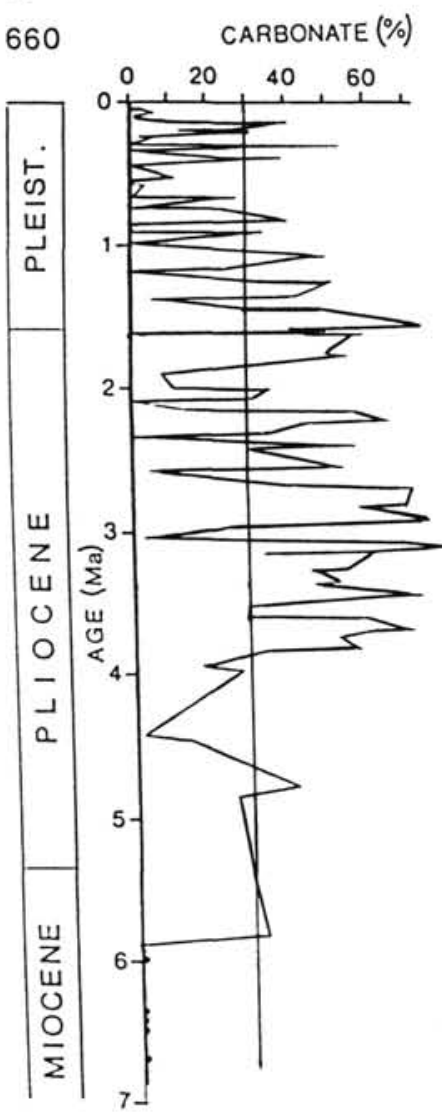
CARBONATE QUARTZ
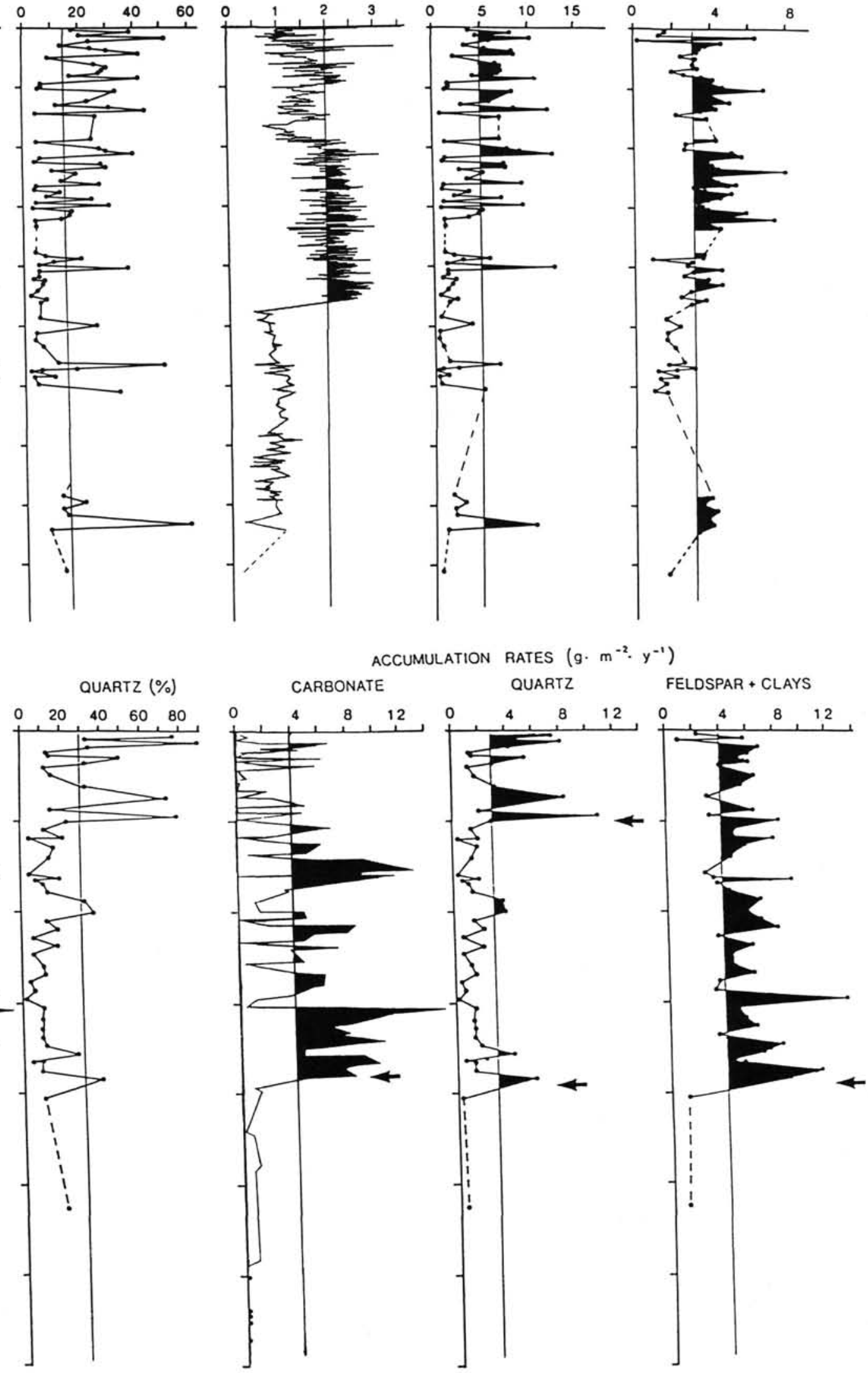

Figure 5 (continued). 
E 661
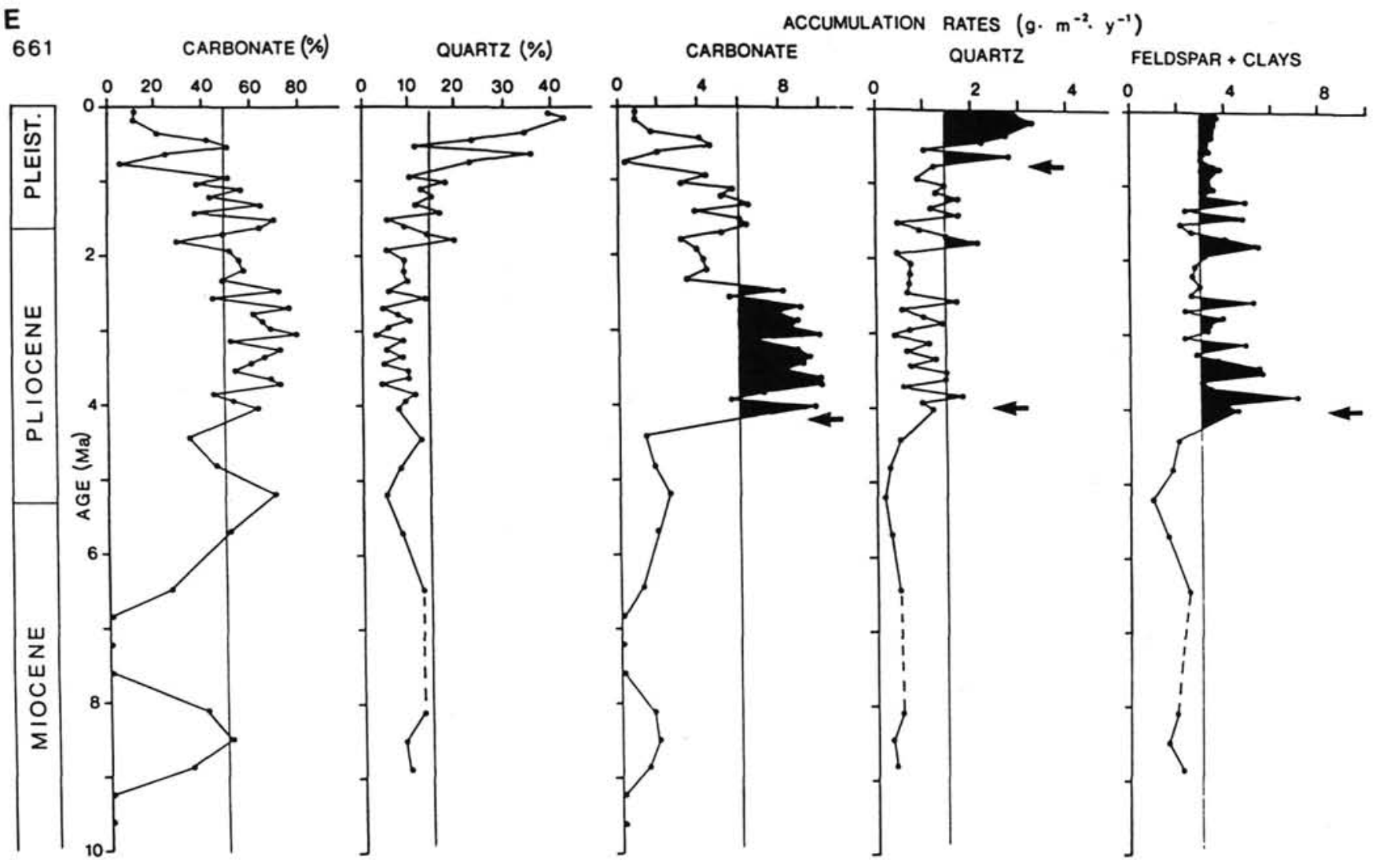

Figure 5 (continued).

$\mathrm{m}^{-2} \mathrm{yr}^{-1}$ (the sum of the accumulation rates of carbonate, opaline, and terrigenous fractions shown in Figs. 5B, 6, and 7) and enable us to decipher many details of change in the sediment sources otherwise lost. Unfortunately, a major hiatus has extinguished any sediment record in the time interval from 1.575 to $0.731 \mathrm{Ma}$ (Sarnthein and Tiedemann, this vol.).

Low carbonate percentages of $<35 \%$ were dominant between 3.6 and 3.1 Ma and between 2.4 and 1.6 Ma (Fig. 5B). From 3.1 to $2.4 \mathrm{Ma}$ and during the last 0.73 m.y., sediments were carbonate richer with most values ranging between $25 \%$ and $60 \%$. Because of dilution effects in the closed percentage system, carbonate accumulation rates show a somewhat different pattern. Maxima of up to $60 \mathrm{~g} \mathrm{~m}^{-2} \mathrm{y}^{-1}$ occurred prior to $2.9 \mathrm{Ma}$. Later, the rates were gradually lowered to $20-40 \mathrm{~g}$ $\mathrm{m}^{-2} \mathrm{yr}^{-1}$ from 2.9 to $1.57 \mathrm{Ma}$. During the Brunhes Chron, the rates again increased to $80-140 \mathrm{~g} \mathrm{~m}^{-2} \mathrm{yr}^{-1}$. Hence, phases of major environmental change occurred near 2.9 and during the hiatus between 1.57 and $0.73 \mathrm{Ma}$.

The biogenic opal content of the carbonate-free silt fraction 2-63 $\mu \mathrm{m}$ (Fig. 6) showed similar events of change during the late Pliocene. It ranged from $0 \%$ to $12 \%$ between 3.55 and $3.1 \mathrm{Ma}$. Thereafter, it increased within a short time to a range of $4 \%-70 \%$ between 3.07 and $2.47 \mathrm{Ma}$ and again decreased to a range from $3 \%$ to $35 \%$ between 2.47 and $1.7 \mathrm{Ma}$. Most opal maxima were linked to interglacial stages (see oxygen isotope record in Fig. 6B) such as later on, during the Brunhes Chron as well.

During the last $0.73 \mathrm{~m} . \mathrm{y}$., the biogenic opal content (Fig. $6 \mathrm{~A})$ fluctuated constantly between $0 \%$ and $12 \%$. This range is in line with modern and last glacial biogenic opal concentrations off northwest Africa reported by Koopmann (1981). His modern values culminate near $4 \%$ below the upwelling cell at $21^{\circ} \mathrm{N}$, near Site 658 , and offshore from the Senegal mouth, as compared to an average of about $1 \%$ along the continental slope and much lower values further offshore. During the Last Glacial Maximum, the regional maxima of biogenic opal reached up to $15 \%$. Superimposed on this background level, the Brunhes Chron record at Site 658 revealed a few shortterm events when concentrations reached more than $25 \%$ and up to $70 \%$. In comparison with the modern abundance patterns, these events appear very unusual and difficult to explain. They were confined to the rise of interglacial Event 11.3 and to the top of interglacial Events 15.3, 13.1/13.3, 9.3, and 7.5 (sensu Prell et al., 1986). A further, smaller maximum of $17 \%$ occurred at the warm interstadial Event 8.5, but none at Events 5.5 and 1.1 .

In general, the fluctuations of opal accumulation rates (Fig. 6), which are based on detailed estimates of sedimentation rates, well confirm the trends and features suggested by the opal percentages. During the early late Pliocene, low rates of less than $2 \mathrm{~g} \mathrm{~m}^{-2} \mathrm{yr}^{-1}$ occurred until $3.07 \mathrm{Ma}$. Subsequently, a fundamental change occurred and the maximum rates increased by a factor of five to $10 \mathrm{~g} \mathrm{~m}^{-2} \mathrm{yr}^{-1}$ near 2.95 (i.e., the time when carbonate accumulation rates started to decrease), $2.78,2.67,2.57$, and $2.5 \mathrm{Ma}$. A basic drift toward lower peak accumulation rates of opal followed until 1.575 Ma. During the Brunhes Chron, approximately constant values of less than $1.0-2.5 \mathrm{~g} \mathrm{~m}^{-2} \mathrm{yr}^{-1}$ persisted ever since, a range that largely matches the values reported by Koopmann (1981) from modern and glacial upwelling-induced high-productivity zones off northwest Africa over the last $20,000 \mathrm{yr}$. In addition, however, we observe a few extreme no-analog maxima of $8-17 \mathrm{~g} \mathrm{~m}^{-2}$ 

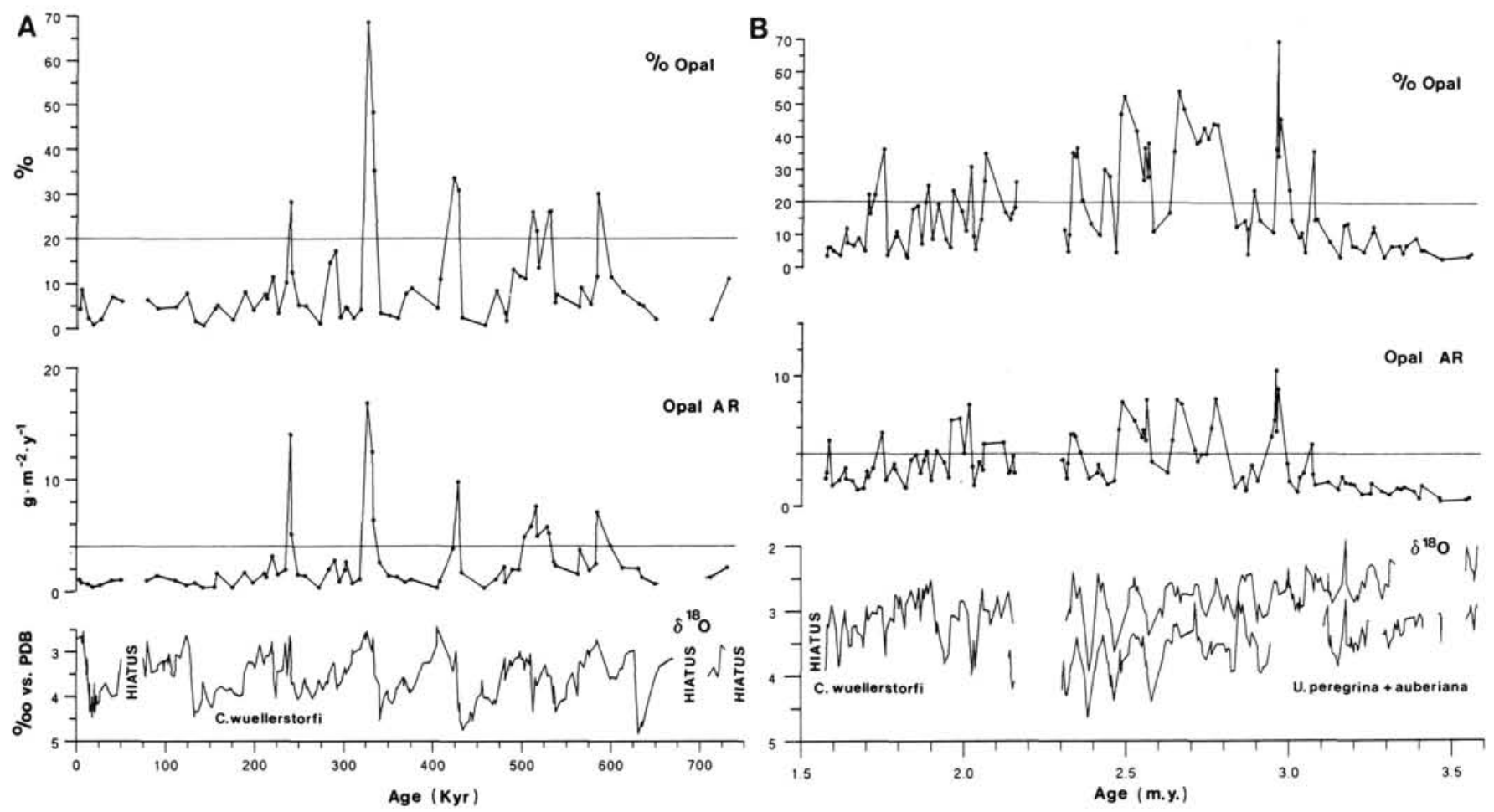

Figure 6. Concentrations (in percent of the carbonate-free sediment fraction 2-63 $\mu \mathrm{m}$ ) and accumulation rates (AR) of biogenic opal, and $\delta^{18} \mathrm{O}$ record (Sarnthein and Tiedemann, this vol.) at Site 658 for the last 0.73 m.y. (A) and 1.5-3.6 m.y. (B).

$\mathrm{yr}^{-1}$, which typified the peak interglacial stages until $230 \mathrm{k} . \mathrm{y}$. and formed major exceptions from the otherwise very uniform Brunhes record. Most of these very brief events lasted only $6000-12,000 \mathrm{yr}$ or less, requiring a special explanation.

The composition of the siliciclastic sediment fraction and its accumulation rates show a number of major long-term and short-term trends (Fig. 7) that, in part, coincide with those of the carbonate and opal fractions.

High (bulk) siliciclastic accumulation rates between 85 and $170 \mathrm{~g} \mathrm{~m}^{-2} \mathrm{yr}^{-1}$ characterized the Pliocene interval 3.6-3.3 Ma. Subsequently, the rates decreased to an average level of $60 \mathrm{~g}$ $\mathrm{m}^{-2} \mathrm{yr}^{-1}$ at $2.9 \mathrm{Ma}$ and fluctuated between 35 and $105 \mathrm{~g} \mathrm{~m}^{-2}$ $\mathrm{yr}^{-1}$ until $1.57 \mathrm{Ma}$. During the Brunhes Chron, the siliciclastic accumulation rates at Site 658 were characterized by highamplitude fluctuations (up to $140 \mathrm{~g} \mathrm{~m}^{-2} \mathrm{yr}^{-1}$ ), which were not always associated with the climatic cycles depicted in the oxygen isotope record (Fig. 7). For the last $500 \mathrm{ka}$, high values generally paralleled the late glacial stages, especially at oxygen isotope Stage 2, Substage 7.4, and the Stage $8 / 9$ boundary. Figure 7 also reveals remarkably sharp increases in siliciclastic accumulation along with the terminations of glacial Stages $6,8,10,12$, and 14 , but not just there. By contrast, the termination of Stage 2 shows a marked decrease.

The percentages of carbonate-free clay $(<2 \mu \mathrm{m})$ in the siliciclastic sediment fraction (Fig. 7) show a basic decrease during the late Pliocene with regard to maximum and minimum percentages. During the last $1.85 \mathrm{~m} . y$. (i.e., approximately the Pleistocene), high clay contents of $60 \%-80 \%$ are linked regularly to interglacial $\delta^{18} \mathrm{O}$ stages (except for Stage 5) and low concentrations of $20 \%$ or less to peak glacial events (Fig. 7).

The long-term flux pattern of clay (Fig. 7B) reflects a striking decrease in clay supply from $100 \mathrm{~g} \mathrm{~m}^{-2} \mathrm{yr}^{-1}$ to $40 \mathrm{~g}$ $\mathrm{m}^{-2} \mathrm{yr}^{-1}$ during the early late Pliocene, from 3.5 to about 2.9
Ma, parallel to the climatic deterioration shown in the $\delta^{18} \mathrm{O}$ curve (Fig. 7B). The interval from 2.9 to $1.57 \mathrm{Ma}$ is marked by frequent fluctuations that range between 25 and $65 \mathrm{~g} \mathrm{~m}^{2} \mathrm{yr}^{-1}$. During the Brunhes Chron, the amplitudes of clay flux slightly increase to a range of about $15-75 \mathrm{~g} \mathrm{~m}^{-2} \mathrm{yr}^{-1}$ and are intimately correlated with the $\delta^{18} \mathrm{O}$ record of Quaternary climate (Fig. 7). Values of up to $65 \mathrm{~g} \mathrm{~m}^{-2} \mathrm{yr}^{-1}$ match interglacial stages, except for Stage $5\left(20 \mathrm{~g} \mathrm{~m}^{-2} \mathrm{yr}^{-1}\right)$. During glacial times, the rates decrease to a low range of between 12 and $20 \mathrm{~g} \mathrm{~m}^{-2} \mathrm{yr}^{-1}$. Hence, the interglacial peaks of bulk siliciclastic accumulation rates that show about the same trend are mainly because of maxima in the input of clay.

The accumulation rates of feldspar plus clay minerals (plus biogenic opal at Site 658) in the bulk samples (Fig. 5B) indicate exactly the same variations and, necessarily, similar flux ranges as the accumulation rates of clay $<2 \mu \mathrm{m}$.

The content of opal- and carbonate-free silt $>6 \mu \mathrm{m}$ in the bulk siliciclastic fraction (Fig. 7) shows a relationship to glacial/interglacial changes, which is opposed to that of the clay fraction, since clay and silt $>6 \mu \mathrm{m}$ form an almost closed percentage system, except for $2 \%-10 \%$ contained in the 2-6 $\mu \mathrm{m}$ grain-size fraction. Pleistocene glacial stages are characterized by high contents of "loess" grain sizes ranging between $50 \%$ and $80 \%$, and interglacial stages by low contents of $15 \%-40 \%$.

Most sediments at Site 658 are characterized by highamplitude variations in quartz content between $10 \%$ and $60 \%$ (Fig. 5B). The only short interval with lower quartz contents of $10 \%$ to $30 \%$ occurred between 3 and $2.3 \mathrm{Ma}$, that is, subsequent to the major decrease of bulk siliciclastic sedimentation rates (Fig. 7).

During the early late Pliocene, when the siliciclastic flux rates were still high, the accumulation rates of quartz showed strong short-term fluctuations and reached maximum values of $50-115 \mathrm{~g} \mathrm{~m}^{-2} \mathrm{yr}^{-1}$ between 3.4 and 3.0 Ma. Later on, the 

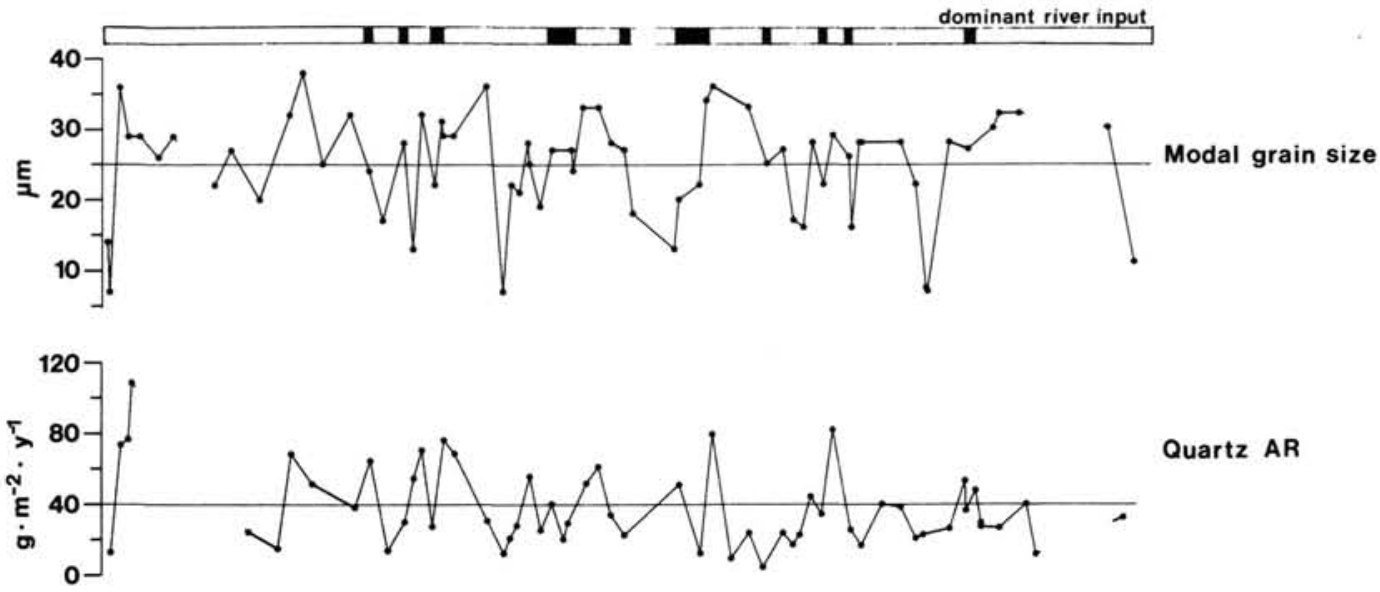

Quartz AR

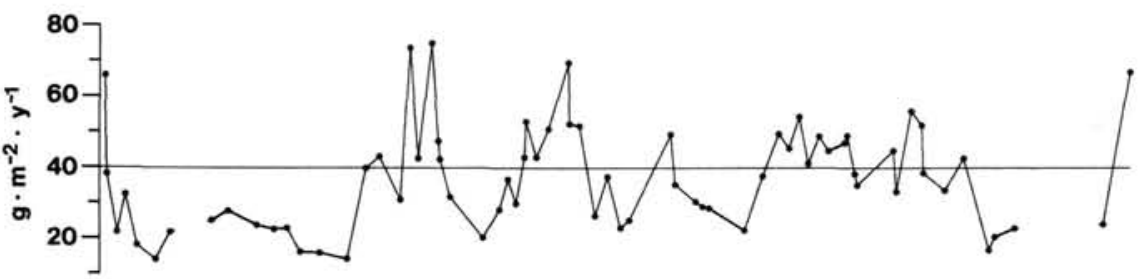

Clay AR

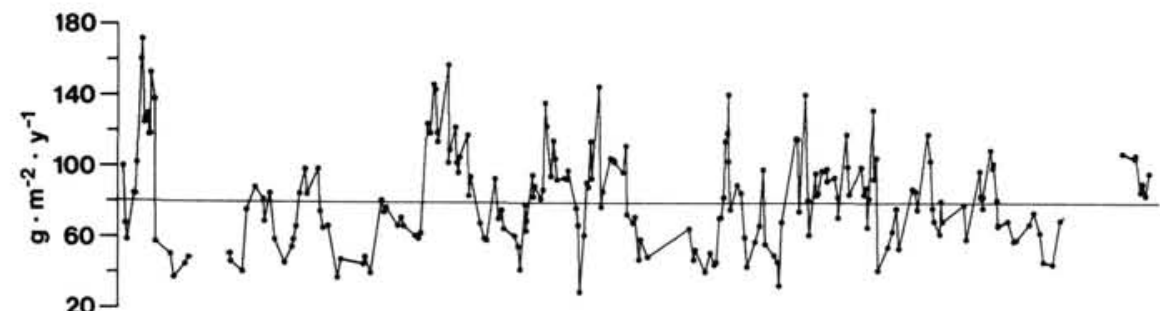

Siliciclastic AR
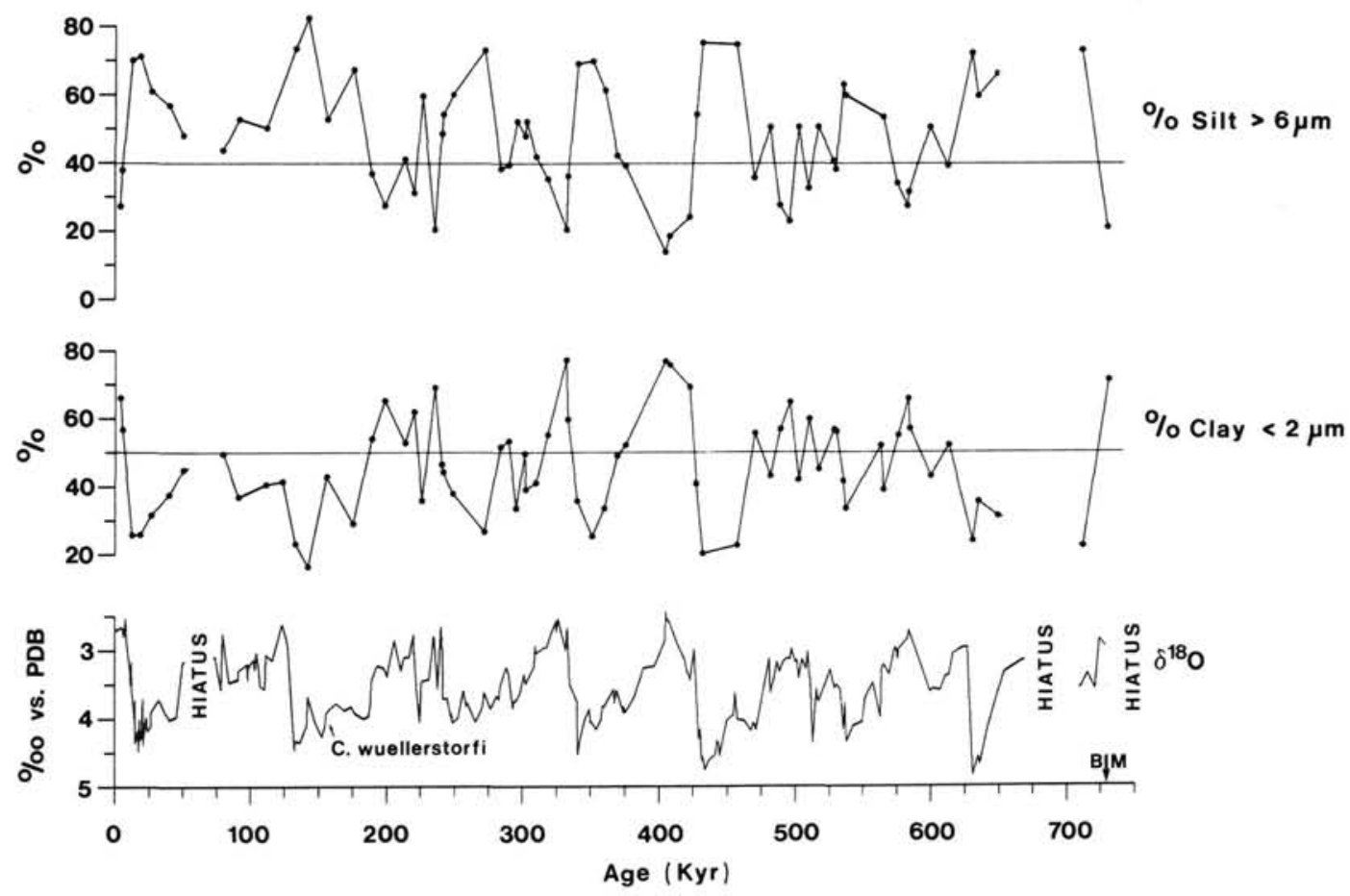

Figure 7. Sedimentary evidence of climatic change at Site 658 for the last 0.73 (A) and 1.5-3.6 m.y. (B): modal grain sizes of the siliciclastic silt fraction $>6 \mu \mathrm{m}$; accumulation rates (AR) of quartz, clay, and the total siliciclastic sediment fraction; contents of clay and silt $>6 \mu \mathrm{m}$ (in percent of the opal- and carbonate-free sediment fraction); and $\delta^{18} \mathrm{O}$ records (Sarnthein and Tiedemann, this vol.) with magnetic and biostratigraphic age control points. Black bars at the top margin mark phases of dominant fluvial sediment supply (based on Figs. 3A and 3B). 

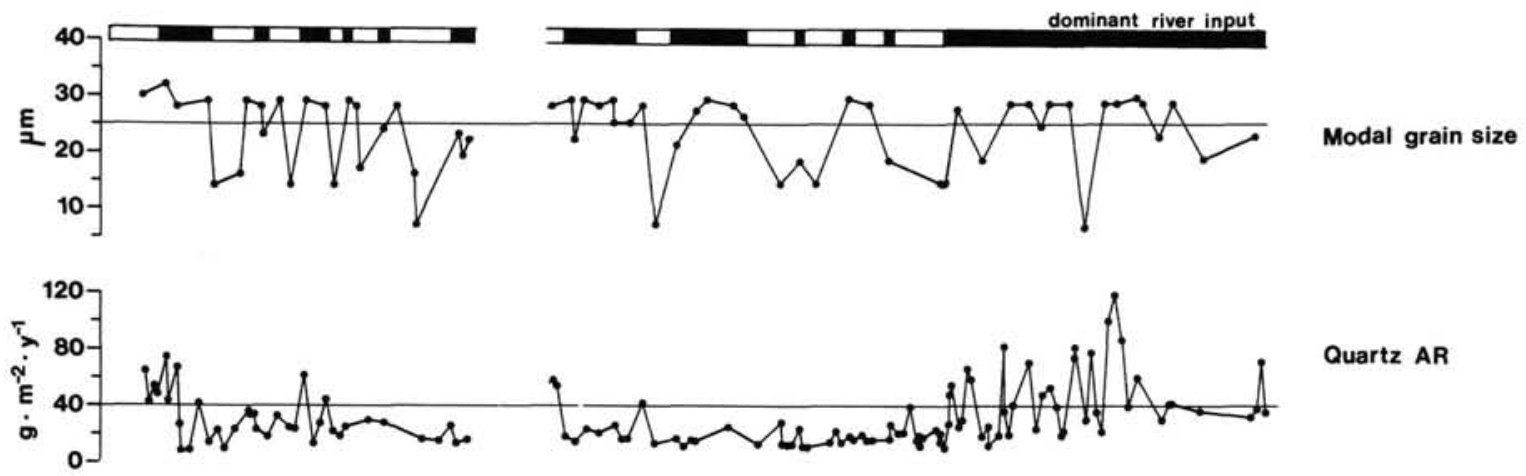

Quartz AR

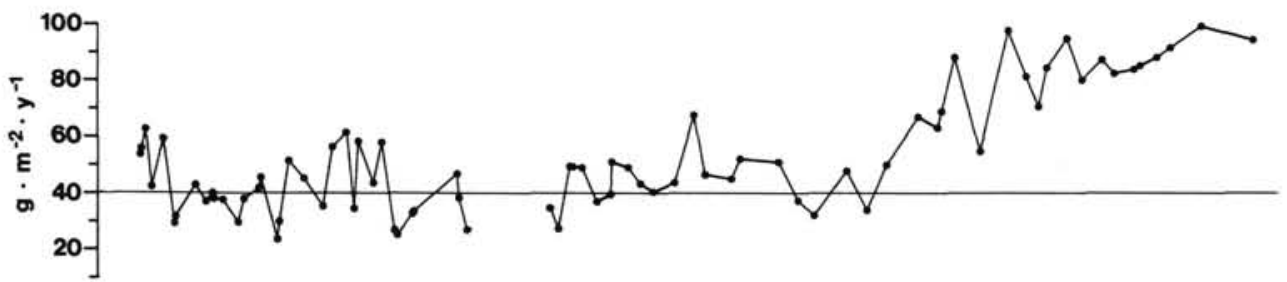

Clay AR

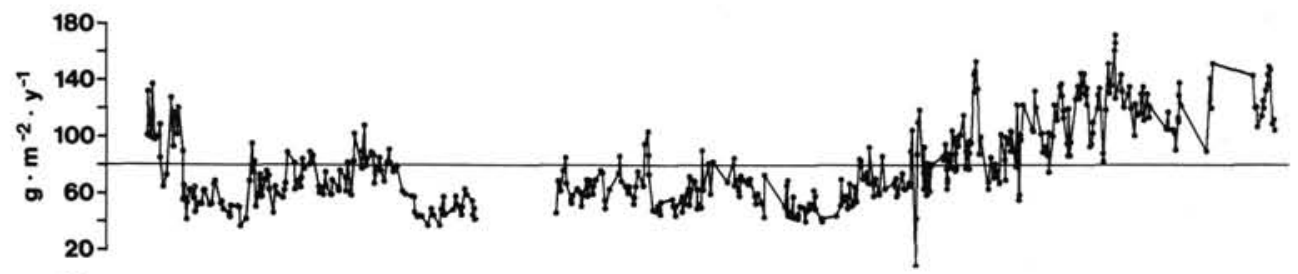

Siliciclastic

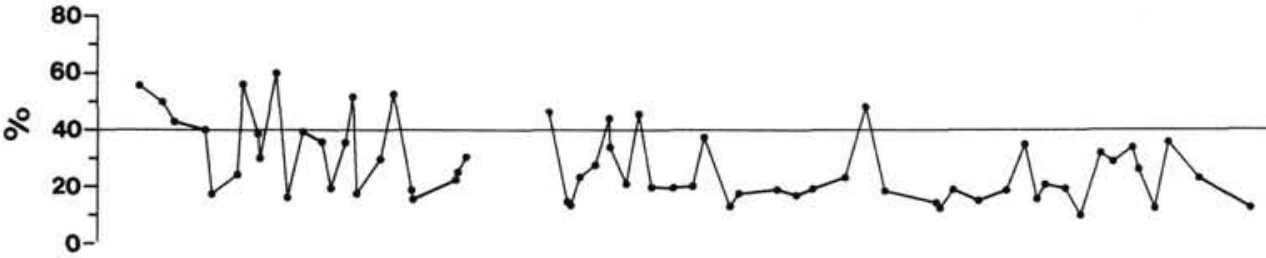

$\%$ Silt $>6 \mu \mathrm{m}$

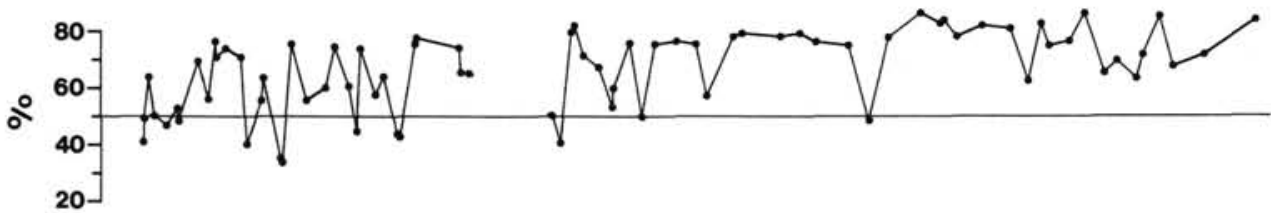

$\%$ Clay $<2 \mu \mathrm{m}$

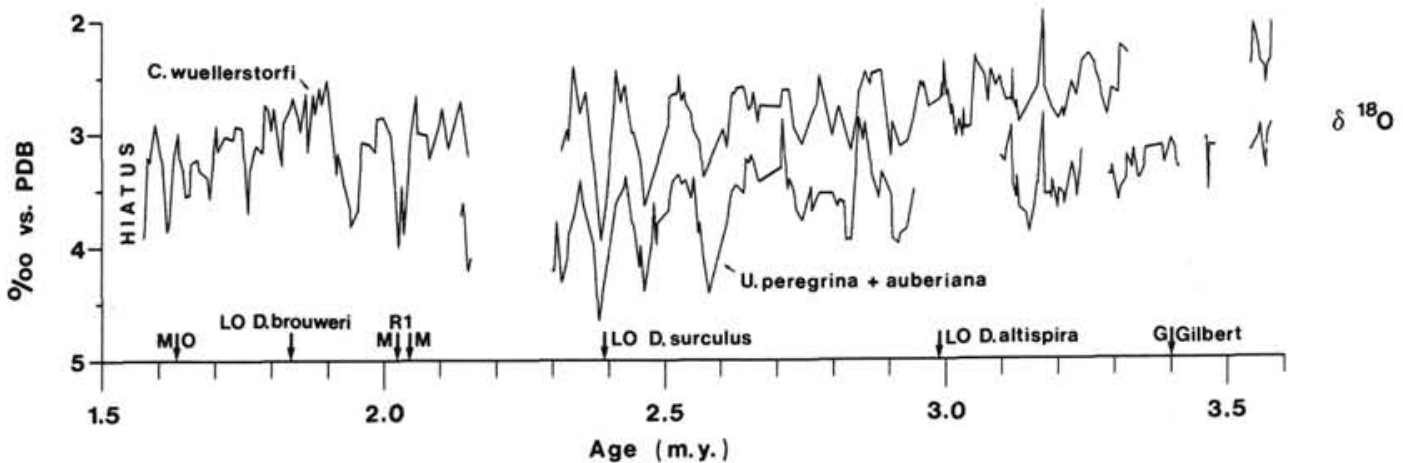

Figure 7 (continued). 

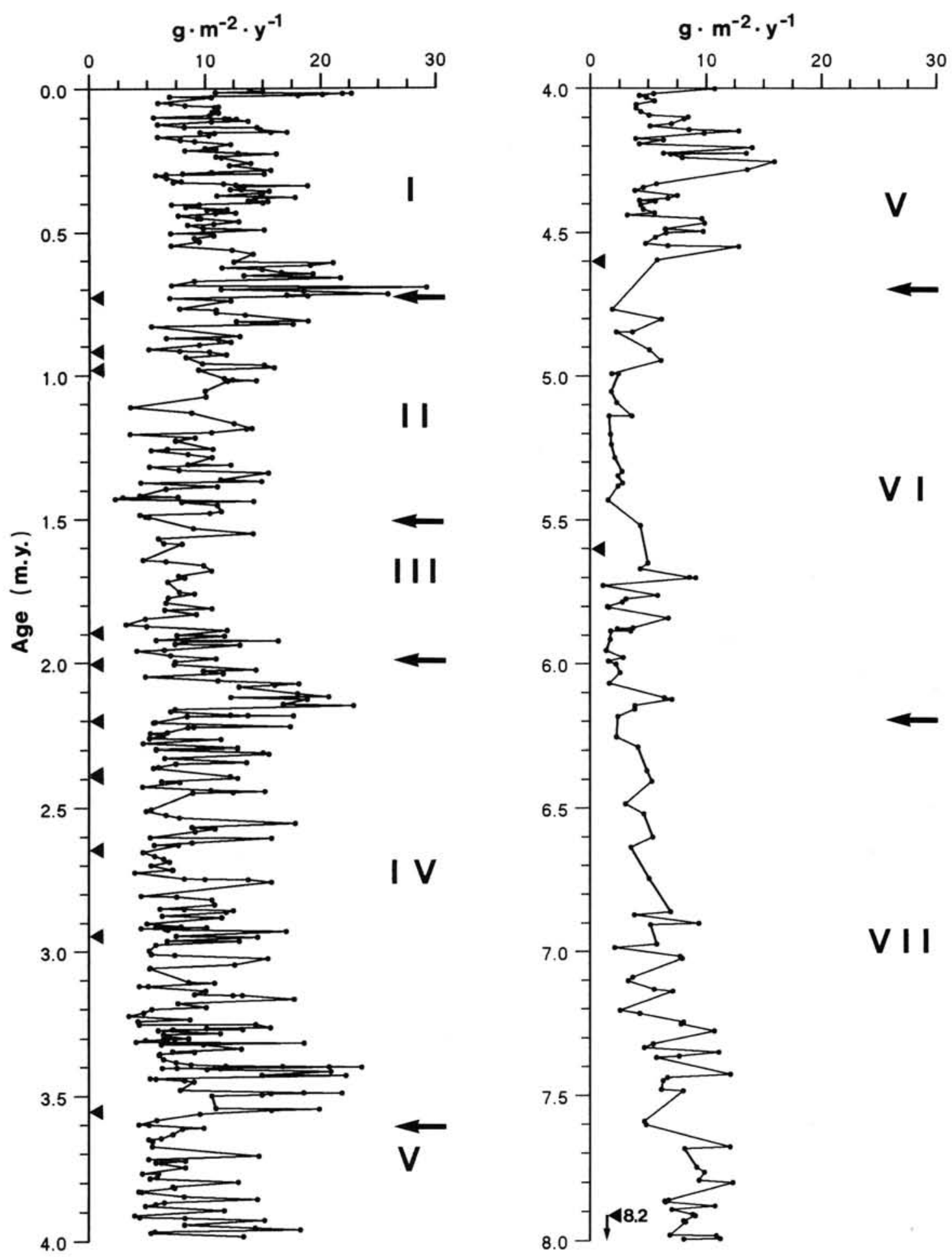

Figure 8. South Saharan aridity record of wind-borne siliciclastic accumulation rates at Site 659 for the last 8 m.y. Magnetic and biostratigraphic age control points indicated at left margin. Major climatic intervals are separated by arrows and are numbered from I to VII. 


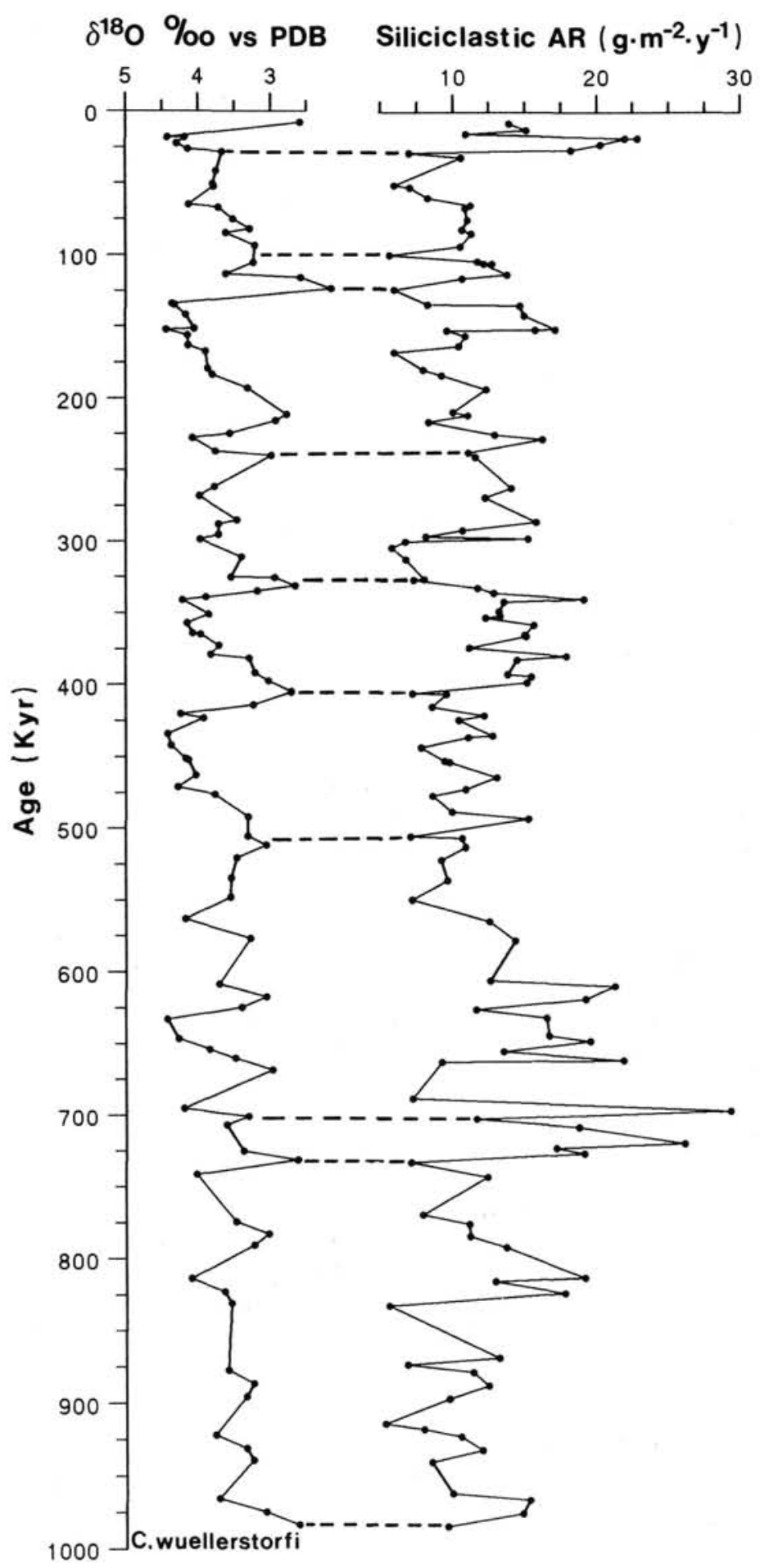

Sed. Rate $\left(\mathrm{cm} \cdot 10^{-3} \cdot \mathrm{y}^{-1}\right)$

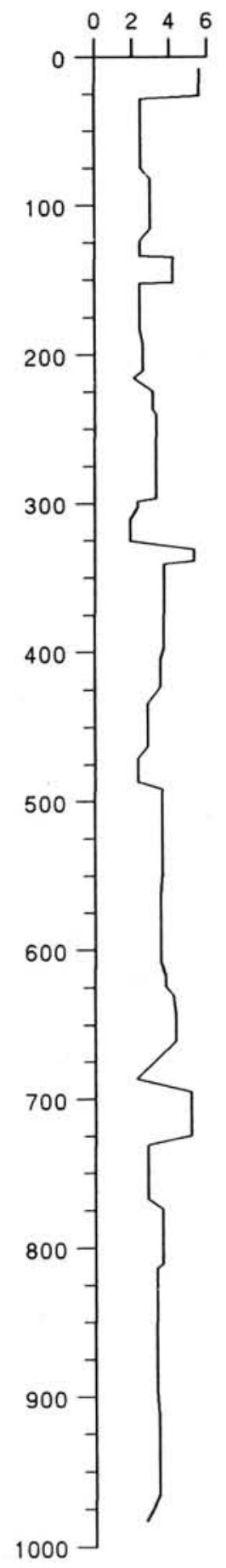

Figure 9. Wind-borne siliciclastic accumulation rates (AR) and bulk sedimentation rates based on age control points of the benthic $\delta^{18} \mathrm{O}$ record and magnetic reversals at Site 659 (Sarnthein and Tiedemann, this vol.) during the last 1 m.y. High siliciclastic AR are linked to south Saharan aridity and generally parallel cold isotopic stages.

flux rates of quartz varied on a low level between 10 and $30 \mathrm{~g}$ $\mathrm{m}^{-2} \mathrm{yr}^{-1}$ until $1.9 \mathrm{Ma}$ and only occasionally reached up to 55 $\mathrm{g} \mathrm{m}^{-2} \mathrm{yr}^{-1}$. High-amplitude fluctuations of up to 80 and $105 \mathrm{~g}$ $\mathrm{m}^{-2} \mathrm{yr}^{-1}$ persisted through the last $1.9 \mathrm{~m} . \mathrm{y}$. of the Pleistocene. In summary, the main reversals in quartz flux rates lay near 3.0 and $1.9 \mathrm{Ma}$.
Furthermore, variations in the modal grain size of the siliciclastic silt fraction $>6 \mu \mathrm{m}$ (Fig. 7) appear to be controlled by climatic change. Modal grain sizes of 11-25 $\mu \mathrm{m}$ generally match Quaternary warm stages. During cold stages, they increase from 28 to $38 \mu \mathrm{m}$. Long-term changes have been minor, except for a slight increase in (glacial) 
Table 3. Turbidite abundance at Site 657 during the last $6.5 \mathrm{~m} . \mathrm{y}$.

\begin{tabular}{ccc}
\hline $\begin{array}{c}\text { Time } \\
\text { intervals } \\
\text { (m.y.) }\end{array}$ & $\begin{array}{c}\text { Total } \\
\text { thickness of } \\
\text { turbidites } \\
(\mathrm{cm})\end{array}$ & $\begin{array}{c}\text { Percentage of } \\
\text { bulk } \\
\text { accumulation rate } \\
(\%)\end{array}$ \\
\hline $0-0.5$ & 68 & 6.0 \\
$0.5-1.0$ & 138 & 8.0 \\
$1.0-1.5$ & 10.5 & 1.0 \\
$1.5-2.0$ & 6 & 0.7 \\
$2.0-2.5$ & 18 & 1.5 \\
$2.5-3.0$ & 174 & 19.3 \\
$3.0-3.5$ & - & 0 \\
$3.5-4.0$ & 8 & 0.5 \\
$4.0-4.6$ & 144 & 7.0 \\
$6.2-6.5$ & 9 & 15.0 \\
\hline
\end{tabular}

peak modal grain sizes to more than $32 \mu \mathrm{m}$ during the Brunhes Chron.

Given the separation scheme deployed in Figure 3, we used the record of both silt modal grain sizes and clay concentrations to decipher the history of aeolian and fluvial sediment supply at Site 658 (Fig. 7, top). In the Pliocene, the relative excess in clay suggests persistent river input dominating terrigenous sedimentation until $3 \mathrm{Ma}$, a point of time generally marked by abrupt change in the depositional record. Later on, a number of samples that belong to the well-sorted sample Group I suggest many intervals when the river input of sediments ceased and eolian dust discharge was dominant, particularly from 3.0 to $2.65 \mathrm{Ma}$, near $2.5 \mathrm{Ma}$, from 2.15 to 2.0 $\mathrm{Ma}$, and from 1.78 to $1.7 \mathrm{Ma}$. The sediment record from the Brunhes Chron was radically different, showing dominant intervals with eolian deposition and only short phases with fluvial input. They were confined to interglacial stages and in most cases, paralleled by extremely high opal excursions (Table 4). No more river input can be recognized after 200 k.y. We assume that this record reflects the long-term gradual aridification of the central Sahara.

Sediment samples of Group III in Figure 3 normally reflect current winnowing (Koopmann, 1981). According to Figure 7, these winnowing events were rare and associated with the peak warm Stages $15.3,8.5$, and 1.1. Possibly, they matched phases of fluvial sediment input.

\section{Site 659}

During the last 8 m.y., carbonate concentrations at Site 659 varied between $30 \%$ and $90 \%$. During the Miocene interval recovered $(5.3-8.5 \mathrm{Ma})$, carbonate values showed a marked overall increase from an average of about $45 \%$ to about $70 \%$ (Fig. 5C). Subsequent to a phase with very high carbonate values from 6.0 to $3.5 \mathrm{Ma}$, both maximum and minimum concentrations indicate a continuous drift toward lower $\mathrm{CaCO}_{3}$ percentages until the present. Different from the $\mathrm{CaCO}_{3}$ concentrations, carbonate accumulation rates remained low at about $10 \mathrm{~g} \mathrm{~m}^{-2} \mathrm{yr}^{-1}$ until about $4.6 \mathrm{Ma}$. After an abrupt increase, they reached a high average level of more than $20 \mathrm{~g} \mathrm{~m}^{-2} \mathrm{y}^{-1}$ until about $2.0 \mathrm{Ma}$ and subsequently decreased to lower, but strongly fluctuating, values of $10-25 \mathrm{~g}$ $\mathrm{m}^{-2} \mathrm{yr}^{-1}$ (Fig. 5C).

Quartz percentages varied between $5 \%$ and $50 \%$ throughout the entire section, with possibly a larger frequency of higher values during the last $3.2 \mathrm{~m}$.y. (Fig. 5C). Our record is aliased by low sampling density. Statistics, however, show that two thirds of the values lie above the $15 \%$ line since 3.2 $\mathrm{Ma}$, but only one fourth of them before $3.2 \mathrm{Ma}$. The accumulation rates of quartz varied between 1 and $13 \mathrm{~g} \mathrm{~m}^{-2} \mathrm{yr}^{-1}$
Table 4. Stratigraphic position and opal contents of samples with relative excess of clay (Fig. 3), suggesting fluvial sediment supply at Site 658 during the last 730 k.y.

\begin{tabular}{llr}
\hline \multicolumn{1}{c}{$\delta^{18} \mathrm{O}$} & $\begin{array}{c}\text { Samples with } \\
\text { suggested fluvial } \\
\text { events }\end{array}$ & $\begin{array}{c}\text { Opal concentrations } \\
\text { in the carbonate-free } \\
\text { fraction } 2-63 \mu \mathrm{m} \\
(\%)\end{array}$ \\
\hline 7.1 & $4 \mathrm{~A}-2,102 \mathrm{~cm}$ & 8.1 \\
$7.31 / 7.33$ & $4 \mathrm{~A}-4,102 \mathrm{~cm}$ & 6.7 \\
7.51 & $5 \mathrm{~A}-1,102 \mathrm{~cm}$ & 10.2 \\
7.53 & $5 \mathrm{~A}-2,70 \mathrm{~cm}$ & 28.2 \\
$9.2 / 9.3$ & $6 \mathrm{~A}-5,102 \mathrm{~cm}$ & 4.3 \\
$9.3 / 10.0$ & $6 \mathrm{~A}-7,70 \mathrm{~cm}$ & 48.5 \\
10.1 & $6 \mathrm{~A}-7,98 \mathrm{~cm}$ & 35.4 \\
11.1 & $7 \mathrm{~A}-4,102 \mathrm{~cm}$ & 7.8 \\
11.3 & $8 \mathrm{~A}-1,102 \mathrm{~cm}$ & 11.2 \\
$11.3 / 12.0$ & $8 \mathrm{~A}-2,102 \mathrm{~cm}$ & 33.8 \\
$12.1 / 12.2$ & $8 \mathrm{~A}-3,26 \mathrm{~cm}$ & 31.2 \\
12.4 & $8 \mathrm{~A}-6,102 \mathrm{~cm}$ & 8.6 \\
$13.15 / 13.2$ & $9 \mathrm{~A}-5,102 \mathrm{~cm}$ & 26.1 \\
13.3 & $10 \mathrm{~A}-1,70 \mathrm{~cm}$ & 26.2 \\
15.5 & $11 \mathrm{~A}-3,104 \mathrm{~cm}$ & 8.4 \\
\hline
\end{tabular}

Note: Two further opal maxima occur outside from intervals with relative excess of clay.

throughout the section. High values are more frequent during the last 4.0 m.y. (Fig. 5C). The accumulation rates of feldspar/clay varied between 1 and $8 \mathrm{~g} \mathrm{~m}^{-2} \mathrm{yr}^{-1}$ and indicate a concentration of minimum values around $2 \mathrm{~g} \mathrm{~m}^{-2} \mathrm{yr}^{-1}$ in the uppermost Miocene and an increase to higher values during the last 3.2 m.y. (Fig. 5C).

The long-term record of siliciclastic accumulation rates (Fig. 8), which reflect the flux rates of essentially carbonatefree SAL dust (Fig. 3C), strongly fluctuated between 1 and $30 \mathrm{~g} \mathrm{~m}^{-2} \mathrm{yr}^{-1}$ during the last $8 \mathrm{~m} . \mathrm{y}$. The record displays seven major intervals (I-VII), a subdivision based on the events shown in the record of 13-point running averages (Fig. 11). Siliciclastic flux rates decreased from 8 to $6.2 \mathrm{Ma}$ (Interval VII), followed by a minimum of about $2.5 \mathrm{~g} \mathrm{~m}^{-2}$ $\mathrm{yr}^{-1}$ that continued until $4.7 \mathrm{Ma}$ (Interval VI). From 4.6 to $3.6 \mathrm{Ma}$ (Interval V), the accumulation rate strongly fluctuated between 5 and $25 \mathrm{~g} \mathrm{~m}^{-2} \mathrm{yr}^{-1}$ with sharp increases at 4.3 and 4.0 Ma. After 3.6 Ma, two pronounced maxima from 3.6 to 3.4 and from 2.2 to $2.05 \mathrm{Ma}$ frame Interval IV, characterized by a persistently high fluctuation range. After a short Interval III of decreasing accumulation rates down to about $5 \mathrm{~g} \mathrm{~m}^{-2} \mathrm{yr}^{-1}$ from 2.05 to $1.5 \mathrm{Ma}$, the average flux rates again reached a higher level of $5-15 \mathrm{~g} \mathrm{~m}^{-2} \mathrm{yr}^{-1}$ (Interval II). Over the last 0.73 m.y. (Interval I), siliciclastic accumulation rates inversely paralleled the $\delta^{18} \mathrm{O}$ record (Fig. 9). Most maxima (up to $29 \mathrm{~g} \mathrm{~m}^{-2} \mathrm{yr}^{-1}$ ) were linked to heavy $\delta^{18} \mathrm{O}$ values, especially to isotope Stages 2, 6, 10, 16, 18, and 22 . Minimum accumulation rates of about $5-10 \mathrm{~g} \mathrm{~m}^{-2} \mathrm{yr}^{-1}$ were most frequent during interglacial times, with a pronounced minimum between 400 and 550 k.y.

\section{Site 660}

The carbonate record of Site 660 is characterized by cyclic high-amplitude variations ranging between $0 \%$ and $75 \%$. During the Pleistocene, maximum carbonate contents decreased to less than $50 \%$ (Fig. 5D). Quartz percentages ranged between $5 \%$ and $40 \%$ during Pliocene times. During the last 1 m.y., quartz contents reached values up to $90 \%$ (Fig. 5D).

A distinct change in bulk accumulation rates occurred near 4.0 Ma (Fig. 5D, the sum of the accumulation rates of quartz, carbonate, and feldspar plus clay). Accumulation rates of carbonate, quartz, and feldspar/clay were low prior to $4.0 \mathrm{Ma}$ 
$\left(<1 \mathrm{~g} \mathrm{~m}^{-2} \mathrm{yr}^{-1}\right.$; Fig. 5D). During the last 3.8 m.y., the carbonate accumulation rates ranged between 0 and $14 \mathrm{~g} \mathrm{~m}^{-2}$ $\mathrm{yr}^{-1}$, with two distinct maxima at 3.8-3.1 and 1.5 Ma. From 3.8 to $1.0 \mathrm{Ma}$, the rates of quartz varied between 1 and $4 \mathrm{~g} \mathrm{~m}^{-2}$ $\mathrm{yr}^{-1}$ and those of feldspar/clay between 1 and $13 \mathrm{~g} \mathrm{~m}^{-2} \mathrm{yr}^{-1}$. Quartz accumulation rates reached their maximum value of 11 $\mathrm{g} \mathrm{m}^{-2} \mathrm{yr}^{-1}$ only during the last $1 \mathrm{~m}$.y.; during the same time, carbonate deposition decreased.

Similar to Site 659 , the siliciclastic accumulation rates (Fig. 10) of Site 660 show a persistently low level of about $3 \mathrm{~g} \mathrm{~m}^{-2}$ $\mathrm{yr}^{-1}$ from 7 to $3.9 \mathrm{Ma}$, although this record may be strongly biased because of the very low sampling density. After a major increase about $3.9 \mathrm{Ma}$, the values fluctuated between 2.5 and $20 \mathrm{~g} \mathrm{~m}^{-2} \mathrm{yr}^{-1}$ until $1.2 \mathrm{Ma}$, with two marked minima at 2.9-2.7 Ma and about $1.8 \mathrm{Ma}$. The rates reached a fairly constant level of about $9 \mathrm{~g} \mathrm{~m}^{-2} \mathrm{yr}^{-1}$ from 1.2 to $0.48 \mathrm{Ma}$ and increased to about $13 \mathrm{~g} \mathrm{~m}^{-2} \mathrm{yr}^{-1}$ during the last $0.5 \mathrm{~m} . \mathrm{y}$.

\section{Site 661}

During the late Miocene, carbonate percentages varied between $0 \%$ and $50 \%$ (Fig. $5 \mathrm{E}$ ). At the base of the Pliocene, carbonate contents distinctly increased to $40 \%-80 \%$ and again decreased to low values of $10 \%-50 \%$ about $1 \mathrm{Ma}$. The $\mathrm{CaCO}_{3}$ accumulation rates remained low during the late Miocene and earliest Pliocene $\left(<3 \mathrm{~g} \mathrm{~m}^{-2} \mathrm{yr}^{-1}\right)$. At $4.1 \mathrm{Ma}$, the rates markedly increased to a high level of about $8 \mathrm{~g} \mathrm{~m}^{-2} \mathrm{yr}^{-1}$ and decreased to $1 \mathrm{~g} \mathrm{~m}^{-2} \mathrm{yr}^{-1}$ after 2.5 Ma.

Quartz contents were low between 9 and $1 \mathrm{Ma}(5.5 \%-15 \%$; Fig. 5E). During the last $1 \mathrm{~m} . y .$, the values increased markedly, up to $40 \%$. Accumulation rates of quartz increased from values of $<0.5$ to values of $1-2 \mathrm{~g} \mathrm{~m}^{-2} \mathrm{yr}^{-1}$ near $4 \mathrm{Ma}$, and those of feldspar/clay from values of 2 to values of $3-8 \mathrm{~g} \mathrm{~m}^{-2}$ $\mathrm{yr}^{-1}$. During the last $1 \mathrm{Ma}$, maximum quartz accumulation rates amounted to $\sim 3 \mathrm{~g} \mathrm{~m}^{-2} \mathrm{yr}^{-1}$ (Fig. 5E), which is much less than at neighboring Site 660 . The difference may be caused by poor age controls. The siliciclastic accumulation record of Site 661 largely resembles that of Site 660 , although with a low sampling resolution.

\section{DISCUSSION}

Most information on long-term (as well as short-term) climatic change in North Africa is based on the deep-sea sediment record. This evidence is superior to land-based records (e.g., Maley, 1980) because it is generally far more complete and precisely dated. Furthermore, it offers the opportunity of direct correlation with many other deep-sea records on the evolution of global climate in high and low latitudes.

Overviews on the late Neogene history of north Saharan aridity were presented by Sarnthein et al. (1982) and Stein (1985a), with both reports determined mainly from evidence taken at (rotary drilled) DSDP Site 397 at $27^{\circ} \mathrm{N}$ (Fig. 1). They concluded that the Quaternary style of increased trade winds and intermittent events of strong (North Saharan) aridity commenced about 3.2 Ma, intensified about $2.45 \mathrm{Ma}$, and possibly intensified again at $0.7 \mathrm{Ma}$.

Sites 657-661 provide various and partly conflicting lines of evidence on long-term change in African climate (summarized in Fig. 11). At Site 659, the accumulation rates of bulk siliciclastic sediment (Fig. 8) show in great detail several pronounced variations of westward dust flux in the AEJ and, accordingly, in south Saharan aridity. For comparison, a low-resolution record such as that at Site 660 (Fig. 10) could lead to considerable misinterpretation of these long-term trends, because the long-term increase in dust flux has actually been linked to strong increases in short-term flux variability as shown for Site 659 and, hence, may be lost at Site 660 by the low sampling resolution prior to $4.0 \mathrm{Ma}$. The cyclical alternations in aridity vs. humidity and in the basic moisture budget of the African monsoon are much enhanced during long-term aridification, whereas the minimum level in dust flux has been remarkably persistent throughout the last $8 \mathrm{~m}$.y. This conclusion is based on the unproven assumption that the short-term fluctuations in siliciclastic accumulation rates are caused by changes in dust flux rates only and not by changes in $\mathrm{CaCO}_{3}$ dissolution between fairly distant age control points (Figs. 5A-5E). This alternative can be decided at Site 659 only for the last $1 \mathrm{~m} . \mathrm{y}$., where $\delta^{18} \mathrm{O}$ stratigraphy provides detailed age control.

During the late Miocene, about 7.2-4.7 Ma, the maximum and minimum flux rates of bulk dust, quartz, and feldspar plus clay (Figs. 5C, 8, and 10) have decreased substantially, by more than $50 \%$ below the average minimum level of the last 8 m.y. This implies an extended humid phase with reduced dust generation in the south Sahara, which compares well with a minimum in both trade-wind-supplied dust and inferred north Saharan aridity documented at Site 397 (Stein, 1985a). With an extreme low of siliciclastic accumulation rates at 5.7-5.0 Ma, the humid phase also matches the Messinian salinity crisis (Müller and Hsü, 1987). Prior to the calculation of an atmospheric circulation model, however, we do not understand the mechanism by which a dried-up Mediterranean Sea has led to humidification of the Sahara, whether by a southward expansion of westerly disturbances or by a northward transport of monsoonal moisture (see below).

As evident in the siliciclastic accumulation record of Site 659 , the subsequent early Pliocene climatic deterioration of the south Sahara turns out to be far more complex than suggested earlier (Figs. 8 and 11). The first, still modest aridity cycles started to become effective immediately after the Messinian at 4.6 Ma. This is much earlier than reported for the northern Sahara by Sarnthein et al. (1982), Suc (1984), and Stein (1985a). The severity of arid events further increased in several steps, at $4.3 \mathrm{Ma}$ and especially at 4.0 and $3.6 \mathrm{Ma}$. Phases of maximum aridity occurred at 3.6-3.4 Ma and 2.2-2.05 Ma. Intermittent, more humid phases lasted from $\sim 2.75$ to $2.6 \mathrm{Ma}(3.0-2.7 \mathrm{Ma}$ at Site 660$)$ and from 1.9 to 1.5 Ma. The last $8 \mathrm{~m} . \mathrm{y}$. were marked by a series of very severe arid events and an extended humid phase about $0.4-0.6 \mathrm{Ma}$ ( $\delta^{18} \mathrm{O}$ Stages $12-15$; Fig. 9). This history of the last $8 \mathrm{~m} . \mathrm{y}$., unfortunately, does not match the (East) African continental record of climatic change as reported, for example, by Bonnefille (1985).

Relative to the records of bulk siliciclastic accumulation, the sequence of climatic events appears to be reduced and somewhat modified in the accumulation rates of quartz and feldspar plus clay at Sites 657 and 659-661 (Figs. 5A, 5C, 5D, and $5 \mathrm{E}$ ), mainly because of lower sampling density. Our records from Sites 659-661 depict a major event of aridification near $4.0 \mathrm{Ma}$, which may identify more closely the timing of an event near $3.8 \mathrm{Ma}$ observed by Pokras and Ruddiman (this vol.) and Pokras (in press) at Sites 662-664. Possibly, their diatom evidence is somewhat aliased because of low sampling resolution. A reinterpretation of their diatom records also suggests a further massive increase in the flux of dustborne freshwater diatoms near 3.5 Ma such as found for the bulk dust flux at Site 659. However, no significant long-term increase in the dust input whatsoever appears at Site 659 about 2.5 m.y. ago, as reported from Sites $662-664$ by Ruddiman and Janacek (this vol.), that is, along with the first major glaciations of the Northern Hemisphere. Actually, none of the Pliocene steps of aridification identified at Sites 659-661 (Fig. 11) was linked to a major glaciation event on the Northern Hemisphere shown in the $\delta^{18} \mathrm{O}$ records (Sarnthein and Tiedemann, this vol.). 


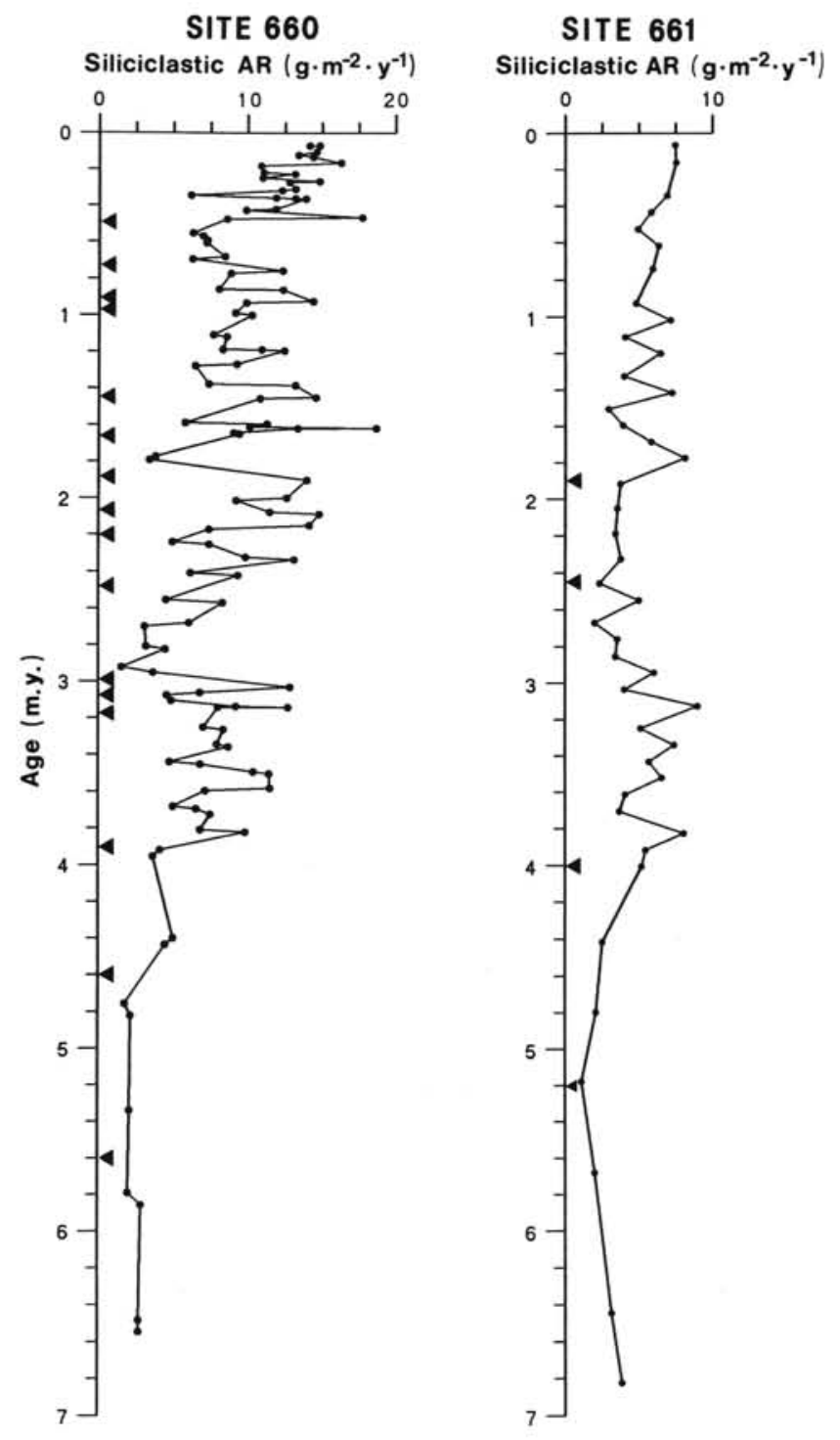

Figure 10. Wind-borne siliciclastic accumulation rates (AR) and magnetic and biostratigraphic age control points at Sites 660 and 661 for the last 6.6 m.y.

Off Cap Blanc, $21^{\circ} \mathrm{N}$, the singular fairly abrupt decline in the input of lithogenic sediment at Site 658 after $3.3 \mathrm{Ma}$ is linked to a loss in the relative excess of (river-borne) clay culminating near 3.0-2.9 Ma (Figs. 7 and 11), a loss that suggests a long-term and gradual dry up of fluvial runoff from the central Sahara. Precisely at the same time, the abrupt increase in the average level of opal accumulation rates suggests the actual onset of the long-term persistent upwelling activity off Cap Blanc. Much as the increase in aridity, it was probably driven by strongly enhanced trade winds, also recognized in the sediment record at Site 397.

From 3.0 to $1.57 \mathrm{Ma}$ and, more rarely, during the last 730 k.y., only a few short-term maxima in the lithogenic input at Site 658 may be related to an occasional return of short-lasting river discharge as discussed below. Dominantly trade-windborne dust deposits have become increasingly important. The major increase in aridity during the early late Pliocene parallels a clear increase in benthic $\delta^{18} \mathrm{O}$ values at Site 658 , which records an expansion of polar ice volume and decreasing deep-water temperatures (Fig. 7; Sarnthein and Tiedemann, this vol.). This aridification event also matches the outlined Site 397 record of a dry up in the north Sahara (Stein, 1985a; Suc, 1984). However, it is not recorded in the south Saharan dust flux history at Sites 659-661. From this divergent evidence, we conclude that the long-term climatic evolution of the north and central Sahara has differed from that of the south Sahara and Sahel Zones. Although the climatic evolution of the north and central Sahara has paralleled the evolution of trade winds and, in general, the variations in north polar ice volume, the history of south Saharan and Sahelian aridity shows no such relationship and possibly has been controlled by changes in Antarctic glaciation (Barron et al., 1988).

A central question is whether the long-term changes in south Saharan aridity have been linked to long-term latitudinal shifts of the ITCZ and to what degree. The latitudinal distribution pattern of SAL-supplied quartz dust and its evolution during the last $6 \mathrm{~m} . \mathrm{y}$. may provide important evidence to answer this question, because the SAL dust flux is linked via the AEJ to the maximum temperature gradient along the ITCZ during northern summer (Tetzlaff and Peters, 1986). Site 659 lies below the center of the modern SAL dust outbreaks. Despite the present lack of pertinent clay mineral data, the regional distribution of quartz accumulation rates (Fig. 12) clearly suggests that Site 659 has persistently received the maximum dust load through the last 4 m.y. when compared with the other more distal sites (657, 660 , and 661).

During this time span, (turbidite-free) quartz accumulation rates at the more northern latitude of Site 657 never have increased relative to those of Sites 659 and 660 during phases of more humid climate, a shift that would suggest a former more northerly position of the outbreak center of dust. Hence, the latitudinal position of the AEJ zonal dust outbreaks and the ITCZ have remained essentially in place (i.e., centered at $18^{\circ} \mathrm{N}$ during the last $4 \mathrm{~m} . \mathrm{y}$.) regardless of major climatic change. Only the diameter of the African dust plume has broadened with ongoing climatic deterioration, as shown by the latitudinal expansion of the enhanced flux of quartz dust about 4 and, especially, 1 Ma (Fig. 12; Sites 657 and 659-661).

Prior to $4.0 \mathrm{Ma}$, the quartz accumulation record of Site 657 unfortunately is disturbed by an uncertain depth placement of biostratigraphic boundaries and a major hiatus from about 4.6 to 6.2 Ma (Ruddiman, Sarnthein, et al., 1988). In case the assigned stratigraphy is all right, the brownish red sediments and high quartz accumulation rates at Site 657 may, indeed, suggest a significant northward shift of the ITCZ-bound dust outbreaks of the SAL during the late Miocene. In this way, a mechanism may be revealed that has led to the long-term and extreme south Saharan humidity prior to 4.0-4.6 Ma, during late Miocene time as reflected by the low dust flux at Site 659 . However, the weak data base of Site 657 makes such a conclusion highly speculative.

Further insights into the processes involved in long-term climatic change may be obtained by analogy with short-term changes in African aridity depicted in the siliciclastic and opal records of Sites 658 and 659 . Compared with oxygen-isotope stratigraphy, AEJ-supplied dust fluxes at Site 659 are in general inversely correlated during the last $1 \mathrm{~m} . \mathrm{y}$. and increased by a factor of 3 to 4 from warm to cold stages (Fig. 9). Glacial stages have also involved an increase in trade-wind speed, as suggested by the general coarsening of siliciclastic grain sizes at Site 658 (Fig. 13). This trend, however, is aliased because occasional fluvial sediment discharge has led to a partial overprint of the dust grain sizes during warm stages (Fig. 3; see below). 


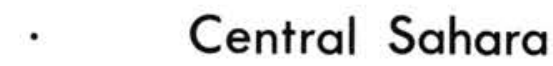

\section{- South Sahara .}

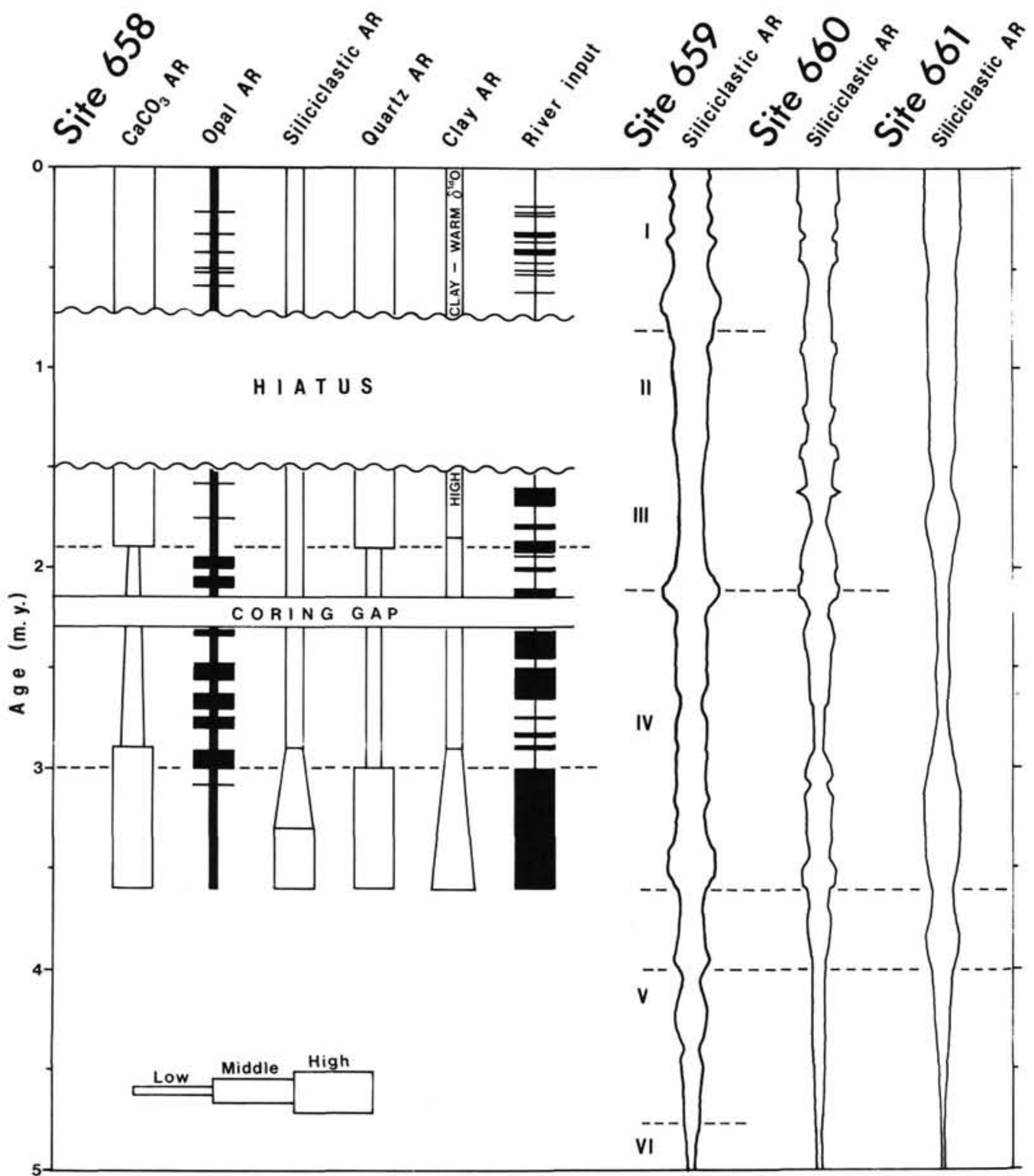

Figure 11. Central and south Saharan climatic history: schematic summary presentation of various sedimentary records and proxy data from Sites 658-661. Major climatic events are indicated by horizontal lines. Siliciclastic accumulation rates (AR) at Site 659 (13-point running averages) and Sites 660-661 (3-point running averages) reflect the dust discharge from the Sahel and south Sahara and its aridification history. The central Saharan climate is marked by a decrease in river discharge and a simultaneous abrupt increase in biogenic opal near $3 \mathrm{Ma}$, suggesting an increase in coastal upwelling and trade winds.

At Site 658 , some horizons with a relative excess in clay (Fig. 7) indicate extremely short phases of fluvial sediment supply from the central Sahara over the last $1.9 \mathrm{~m} . \mathrm{y}$. They occur at most peak and early warm stages and along with some Alleröd-style warm excursions at terminations (Table 4 and Fig. 7). The short phases of river discharge at Site 658, only lasting for a few thousand years at most, may be also inferred from the pronounced ephemeral peaks in biogenic opal accumulation during warm oxygen isotopic Events 15.3, 13.3, 12.1, 9.31, (8.5), and 7.53 (Fig. 6). These maxima (7-17 $\mathrm{g} \mathrm{m}^{-2} \mathrm{yr}^{-1}$ ), which far exceed the generally high level of opal values along with the local upwelling cell, well compare with peak rates found along the edge of the Congo plume during the last 0.23 m.y. and ascribed to special nutrient supply (Jansen and van der Gaast, 1988).

Marine diatoms constitute most of the opal maxima at Site 658 (Stabell, this vol.). In some cases (e.g., Events 9.31, 7.53, and perhaps 7.3), these peaks match short-lived maxima of Thalassionema nitzschioides (Stabell, this vol.), a marine diatom species which Pokras and Molfino (1986) identified in the vicinity of river-supplied nutrients. Hence, various independent lines of evidence, the short-term occurrence of a relative excess in clay, extreme maxima in opal accumulation, and a diatom species suggest that peak warm phases during the early and middle Brunhes Chron were linked to ephemeral monsoonal moisture supply, strong enough to support a 


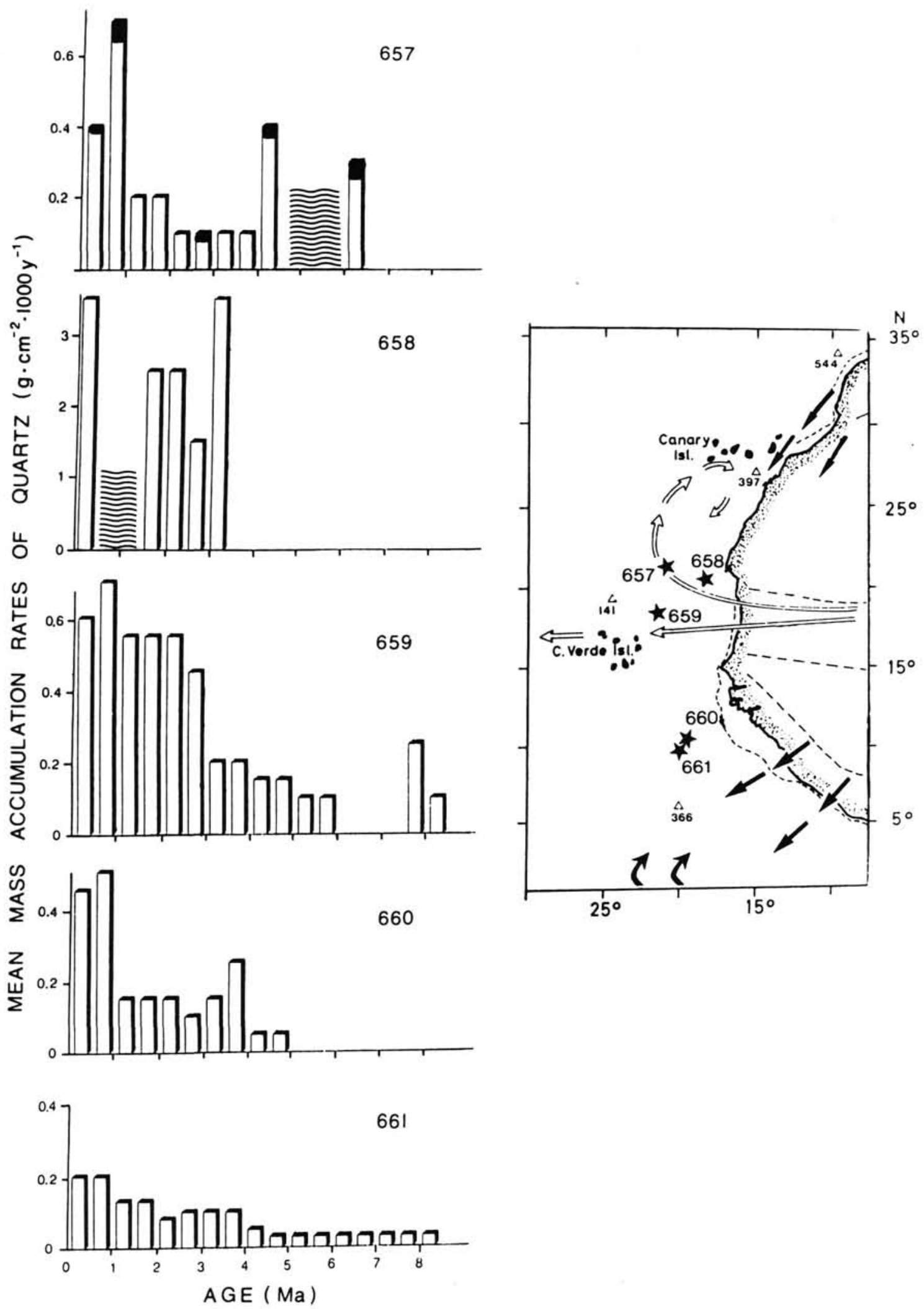

Figure 12. Latitudinal variability of mean quartz accumulation rates at Sites $657-661$, about $9^{\circ}-21^{\circ} \mathrm{N}$, during the last 8 m.y. Turbidite portions at Site 657 are shaded. For an explanation of the insert map, see Figure 1 . The extremely high rates at Site 658 are merely a result of its proximity to the shore and of fluvial sediment discharge. 


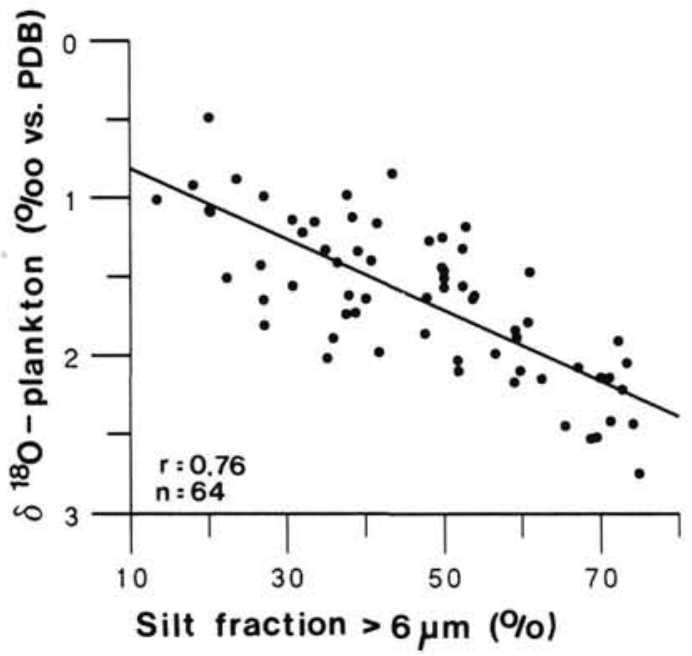

Figure 13. Correlation of percent siliciclastic silt $>6 \mu \mathrm{m}$ vs. planktonic $\delta^{18} \mathrm{O}$ values of $G$. inflata at Site 658 during the last 0.73 m.y.

massive but short-lived runoff of major rivers in the central Sahara.

Variations in equatorial Atlantic SST and the resulting fluctuations in evaporation are a strong candidate for the control of the moisture budget along the ITCZ and south Saharan aridity (Tetzlaff et al., in press). This possible relationship can be tested in the spectral domain of long time series (strategy of Imbrie et al., in press). The south Saharan aridity record of the last 0.5 m.y., documented in the dust accumulation rates at Site 659 (Fig. 9), served for a first spectral analysis test (Fig. 14; Pflaumann, pers. comm. and in press). The time interval from 0 to $0.5 \mathrm{Ma}$ was selected because of its high sampling density (Table 2) and its $\delta^{18} \mathrm{O}$ stratigraphy, providing precise age control and fairly reliable estimates of dust flux rates.

The frequency spectrum of Figure 14 shows significant concentrations of variance in dust flux/aridity at the periods of orbital variation in both the precession (18.9 and 23.3 k.y.) and eccentricity bands (125 k.y.) and, furthermore, at 43.5 k.y., a periodicity perhaps related to the obliquity cycle. The precessional cycles are highly coherent with the periods observed in the record of summer sea-surface temperatures near the meteorological equator (Pflaumann, in press). This coherency is a measure of linear correlation between the signals of evaporation in the equatorial Atlantic and monsoonal moisture in the south Sahara and Sahel Zones over the given frequency bands (at a phase difference of about $180^{\circ}$ ). Thus, the model of modern moisture balance over the Sahel region by Tetzlaff et al. (in press) appears to be in harmony with the results of the fossil record.

More narrow-spaced sampling and more analyses of grain sizes and clay minerals are required to further substantiate this still-fragmentary evidence on the evolution of land climate.

\section{CONCLUSIONS}

Based on detailed vertical and horizontal distribution patterns of windblown dust and river-supplied mud in deep-sea sediments off North Africa, we were able to identify several major trends in the long- and short-term evolution of Saharan climate during the last 8 m.y. (summarized in Figs. 11 and 12).

1. During the latest Miocene and earliest Pliocene, about 7.2-4.7 Ma, a humid climate marked both the north and south Sahara. Later, the evolution of climate became more diversified.

2. The onset of arid climate cycles in the south Sahara occurred stepwise at $4.6,4.3$, and especially at 4.0 and $3.6 \mathrm{Ma}$, with distinct aridity maxima near 3.5 and $2.1 \mathrm{Ma}$. After a more humid phase about 2.0-1.5 Ma, pronounced short-term aridity events paralleled the ice ages of the last $8 \mathrm{~m} . \mathrm{y}$. The long-term evolution showed no obvious relationship to long-term variations in (north) polar ice volume.

3. In contrast to the south Sahara, the aridification of the north Sahara (Site 397) probably started only 3.2 Ma, near

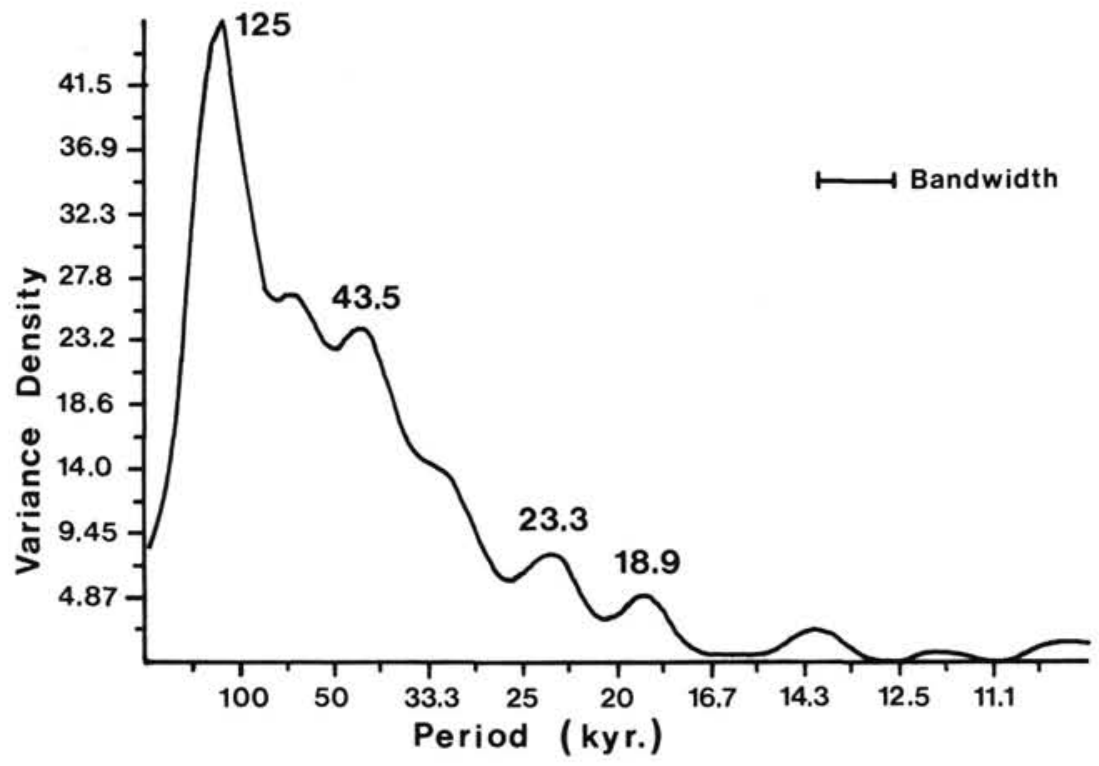

Figure 14. Variance spectra calculated from records of siliciclastic accumulation rates (equivalent to south Saharan aridity) at Site 659 over the last $0.5 \mathrm{~m} . \mathrm{y}$. (smoothed by a 5-k.y. Gaussian filter) (U. Pflaumann, unpubl. data). Spectra are plotted on arbitrary log scales and provided with an $80 \%$ confidence interval. Frequencies are in cycles per k.y. 
the onset of northern hemispheric glaciation. This change also marked the history of the central Sahara, where persistent river discharge at $21^{\circ} \mathrm{N}$ ceased after $3.2-2.9 \mathrm{Ma}$. At the same time, the average flux of opal showed an abrupt increase, suggesting the onset of long-term strongly enhanced trade winds via an onset of coastal upwelling activity. Given the special, very short-lived maxima of opal and the relative excess in clay, marked pulses of ephemeral runoff, however, can be recognized throughout the Brunhes Chron, strictly matching peak interglacial stages. In conclusion, the familiar $18-\mathrm{k} . \mathrm{y}$. ice age/aridity pattern seems to hold for the short-term aridity fluctuations during the last 8 m.y. The connection is also valid for the long-term evolution of the north and central Sahara and the trade winds, but apparently it does not apply to the long-term history of the south Sahara and Sahel.

4. The spatial and temporal distribution of quartz accumulation rates suggests that the center of Saharan dust outbreaks has remained essentially in place at $18^{\circ} \mathrm{N}$ over the last 4 m.y., regardless of major climatic change. This implies that the AEJ and the ITCZ during the northern summer did not shift in latitude. Based on quartz accumulation rates at Site 657 , one may speculate whether the ITCZ-related dust outbreaks occurred several degrees of latitude further north prior to 4-5 Ma.

5. Preliminary time-series analyses of south Saharan dust flux variations reveal a 43.5-k.y. period and strong 19-, 23-, and $125-\mathrm{k} . \mathrm{y}$. periods. Their coherency with the precessional frequencies of an equatorial sea-surface temperature record suggests that the dust/aridity cycles are correlated, in part, to a low-latitudinal forcing (i.e., to the sea-surface temperature and evaporation regime of the equatorial Atlantic).

\section{ACKNOWLEDGMENTS}

U. Pflaumann kindly provided unpublished results from timeseries analyses of Site 659 sediment data. V. Breyer, U. Glahn, R. Kantz, J. J. Knaack, and R. Günther assisted with processing the large numbers of sediment samples. We thank two anonymous reviewers for critical comments on the manuscript and, in particular, W. F. Ruddiman for his numerous valuable suggestions on how to improve the manuscript. This research was supported by DFG grants Sa $207 / 28$ and Ste $412 / 1$.

\section{REFERENCES}

Barron, J., Larsen, B., and the ODP Leg 119 Scientific Party, 1988. Leg 119 studies climate history. Geotimes, 33:14-16.

Bohrmann, G., 1986. Accumulation of biogenic silica and opal dissolution in upper Quaternary Skagerrak sediments. Geo-Mar. Lett., 6:165-172.

Bonnefille, R., 1985. Evolution of the continental vegetation: the palaeobotanical record from East Africa. S. Afr. J. Sci., 81: 267-270.

Brazel, A. J., 1986. Effect of antecedent moisture conditions on dust storm generation in Arizona. 17th Annu. Binghamton Geomorph. Symp. on Aeolian Geomorphology, Sept. 27-28, 1986 (Guelph, Ontario). (Abstract)

Carlson, T., and Prospero, J., 1977. Sahara air outbreaks: meteorology, aerosols, and radiation. Rept. U.S. Gate Central Program Workshop (NCAR), Boulder, Colorado, 57-78.

Chamley, H., 1979. North Atlantic clay sedimentation and paleoenvironment since the Late Jurassic. In Talwani, M., Hay, W., and Ryan, W.B.F., et al. (Eds.), Deep Drilling Results in the Atlantic Ocean: Continental Margins and Paleoenvironment: Washington (American Geophysical Union). M. Ewing Ser., 3:342-361.

Cook, H. E., Johnson, P. D., Matti, J. C., and Zemmels, I., 1975. Methods of sample preparation and X-ray diffraction data analysis, X-Ray Mineralogy Laboratory, Deep Sea Drilling Program, University of California, Riverside. In Hayes, D. F., Frakes,
L. A., et al. (Eds.), Init. Repts. DSDP, 28: Washington (U.S. Govt. Printing Office), 999-1007.

Hooghiemstra, H., Agwu, C.O.C., and Beug, H.-J., 1986. Pollen and spore distribution in recent marine sediments: a record of northwest African seasonal wind patterns and vegetation belts. Meteor Forschungsergeb., Reihe C, 40:87-135.

Hooghiemstra, H., Bechler, A., and Beug, H.-J., 1987. Isopollen maps for 18,000 years B.P. of the Atlantic offshore of northwest Africa: evidence for paleowind circulation. Paleoceanography, 2:561-582.

Imbrie, J., Hays, J. D., Martinson, D. G., McIntyre, A., Mix, A. C., Morley, J. J., Pisias, N. G., Prell, W. L., and Shackleton, N. J., 1984. The orbital theory of Pleistocene climate: support from a revised chronology of the marine $\delta^{18} \mathrm{O}$ record. In Berger, A., Imbrie, J., Hays, J., Kukla, G., and Saltzman, B. (Eds), Milankovitch and Climate (Pt. 1): Hingham, MA (D. Reidel), 269-305.

Imbrie, J., McIntyre, A., and Mix, A., 1989. Oceanic response to orbital forcing in the late Quaternary: observational and experimental strategies. In Duplessy, J.-C., Berger, A., and Schneider, S. (Eds.), Climate and Geosciences: Boston (D. Reidel).

Jansen, F., and van der Gaast, S. J., 1988. Accumulation and dissolution of opal in Quaternary sediments of the Zaire deep-sea fan (northeastern Angola Basin). Mar. Geol., 83:1-7.

Kolla, V., Biscaye, P. E., and Hanley, A., 1979. Distribution of quartz in late Quaternary Atlantic sediments in relation to climate. Quat. Res., 11:261-277.

Koopmann, B., 1981. Saharan dust deposition in the northern subtropical Atlantic during the last 25,000 years. Meteor Forschungsergeb., Reihe C, 35:23-59.

Lange, H., 1982. Distribution of chlorite and kaolinite in eastern Atlantic sediments of North Africa. Sedimentology, 29:427-431.

Leinen, M., and Heath, G. R., 1981. Sedimentary indicators of atmospheric circulation in the Northern Hemisphere during the Cenozoic. Palaeogeogr., Palaeoclimatol., Palaeoecol., 36:1-21.

Maley, J., 1980. Les changements climatiques de la fin du Tertiaire en Afrique: leur consequence sur l'apparition du Sahara et de sa vegetation. In Williams, M.A.J., and Faure, H. (Eds.), The Sahara and the Nile: Rotterdam (A. A. Balkema), 63-86.

Middleton, N. J., 1985. Effect of drought on dust production in the Sahel. Nature, 316:431-434.

Mienert, J., Stein, R., Schultheiss, P., and Shipboard Scientific Party, 1988. Relationship between grain density and biogenic opal in sediments from Sites 658A and 660. In Ruddiman, W., Sarnthein, M., et al. (Eds.), Proc. ODP, Init. Repts., 108, Sect. 2: College Station, TX (Ocean Drilling Program), 1047-1053.

Müller, G., 1967. Methods in sedimentary petrology. In Engelhardt, W. V., Füchtbauer, H., and Müller, G. (Eds.), Sedimentary Petrology (Pt. I): Stuttgart (Schweitzerbartsche Verlagsbuchhandlung).

Müller, G., and Gastner, M., 1971. The "Karbonatbombe": a simple device for the determination of the carbonate content in sediments, soils, and other materials. Neues Jahrb. Mineral., Monatsh., 10:466-469.

Müller, D. W., and Hsü, K. J., 1987. Event stratigraphy and paleoceanography in the Fortuna Basin (southeast Spain): a scenario for the Messinian salinity crisis. Paleoceanography, 2:679-696.

Nicholson, S. E., and Flohn, H., 1980. African environmental and climatic changes and the general atmospheric circulation in late Pleistocene and Holocene. Clim. Change, 2:313-348.

Pflaumann, U., in press. Temperaturreaktionen des nordäquatorialen Atlantiks auf globale klima-anfachung wahrend der letzen 750,000 jahre. Paleoklimaforsch. Akad. Wiss. Literat. Mainz.

Pokras, E. M., in press. Early Pliocene aridification of north tropical Africa: preliminary evidence from ODP Sites 662 and 664. In Leinen, M., and Sarnthein, M. (Eds.), Paleoclimatology and Paleometeorology: Modern and Past Patterns of Global Atmospheric Transport. Proc. NATO Advanced Research Workshop.

Pokras, E. M., and Molfino, B., 1986. Oceanographic control of diatom abundances and species distributions in surface sediments of the tropical and southeast Atlantic. Mar. Micropaleontol., 10:165-188.

Prell, W. L., Imbrie, J., Martinson, D. G., Morley, J. J., Pisias, N. G., Shackleton, N. J., and Streeter, H. F., 1986. Graphic correlation 
of oxygen isotope stratigraphy application to the late Quaternary. Paleoceanography, 1:137-162.

Prospero, J. M., 1985. Records of past continental climates in deepsea sediments. Nature, 315:279-280.

Prospero, J. M., and Nees, R. T., 1986. Impact of the North African drought and $\mathrm{El}$ Niño on mineral dust in the Barbados trade winds. Nature, 320:735-738.

Pye, K., 1987. Aeolian Dust and Dust Deposits: London (Academic Press).

in press. Processes of fine particle formation, dust source regions, and climatic changes. In Leinen, M., and Sarnthein, M. (Eds.), Paleoclimatology and Paleometeorology: Modern and Past Patterns of Global Atmospheric Transport. Proc. NATO Advanced Research Workshop.

Raymo, M. E., Ruddiman, W. F., Backman, J., Clement, B. M., and Martinson, D. G., in press. Late Pliocene variation in Northern Hemisphere ice sheets and North Atlantic Deep Water circulation. Paleoceanography.

Rea, D. K., and Janacek, T. R., 1982. Late Cenozoic changes in atmospheric circulation deduced from North Pacific eolian sediments. Mar. Geol., 49:149-167.

Robert, C., and Chamley, H., 1986. La kaolinite des sediments est-Atlantiques, temoin des climates et environnements cénozoiques. C. R. Acad. Sci. Paris, Ser. 2, 303:1563-1568.

Ruddiman, W. F., Raymo, M., and McIntyre, A., 1986. Matuyama 41,000-year cycles: North Atlantic Ocean and Northern Hemisphere ice sheets. Earth Planet. Sci. Lett., 80:117-129.

Ruddiman, W., Sarnthein, M., et al., 1988. Proc. ODP, Init. Repts., 108: College Station, TX (Ocean Drilling Program).

Sarnthein, M., 1978. Sand deserts during glacial maximum and climatic optimum. Nature, 271:43-46.

1979. Indicators of continental climates in marine sediments: a discussion. Meteor Forschungsergeb., Reihe C, 31:49-51.

Sarnthein, M., Erlenkeuser, M., and Zahn, R., 1982. Termination I: the response of continental climate in the subtropics as recorded in deep-sea sediments. Bull. Inst. Geol. Basin Aquitaine, 31:393-407.

Sarnthein, M., and Koopmann, B., 1980. Late Quaternary deep-sea record on northwest African dust supply and wind circulation. Palaeoecol. Afr., 12:239-253.

Sarnthein, M., Tetzlaff, G., Koopmann, B., Wolter, K., and Pflaumann, U., 1981. Glacial and interglacial wind regimes over the eastern subtropical Atlantic and northwest Africa. Nature, 293:193-196.

Sarnthein, M., Thiede, J., Pflaumann, U., Erlenkeuser, H., Fütterer, D. Koopmann, B., Lange, H., and Seibold, E., 1982. Atmospheric and oceanic circulation patterns off northwest Africa during the past 25 million years. In von Rad, U., Hinz, K., Sarnthein, M., and Seibold, E. (Eds.), Geology of the Northwest African Continental Margin: Berlin-Heidelberg-New York (Springer-Verlag), 545-603.

Sirocko, F., and Sarnthein, M., in press. Wind-borne deposits in the northwestern Indian Ocean: record of Holocene sediments versus modern satellite data. In Leinen, M., and Sarnthein, M. (Eds.),
Paleoclimatology and Paleometeorology: Modern and Past Patterns of Global Atmospheric Transport. Proc. NATO Advanced Research Workshop.

Stein, R., 1984. Zur neogenen Klimaentwicklung und Paläoozeanography im Nordostatlantik: Ergebnisse von DSDP-Sites 141, 366, 397 und 544B (Ph.D. dissert). Univ. Kiel, Federal Republic of Germany.

1985a. Late Neogene changes of paleoclimate and paleoproductivity off northwest Africa (DSDP Site 397). Palaeogeogr., Palaeoclimatol., Palaeoecol., 49:47-59.

1985b. Rapid grain-size analyses of silt and clay fractions by Sedigraph 5000D: comparison with Coulter Counter and Atterberg methods. J. Sediment. Petrol., 55:590-593.

1986. Late Neogene evolution of paleoclimate and paleoceanic circulation in the Northern and Southern Hemispheres-a comparison. Geol. Rundsch., 75:125-139.

Stein, R., and Robert, C., 1985. Siliciclastic sediments at Sites 588, 590, and 591: Neogene and Paleogene evolution in the southwest Pacific and Australian climate. In Kennett, J. P., von der Borch, C. C. (Eds.), Init. Repts. DSDP, 90: Washington (U.S. Govt. Printing Office), $1437-1455$.

Stein, R., and Sarnthein, M., 1984. Late Neogene events of atmospheric and oceanic circulation offshore northwest Africa: high-resolution record from deep-sea sediments. Paleoecol. Afr., 16:9-36.

Street, F. A., and Grove, A. T., 1979. Global maps of lake-level fluctuations since 30,000 B.P. Quat. Res., 12:83-118.

Suc, J.-P., 1984. Origin and evolution of the Mediterranean vegetation and climate in Europe. Nature, 307:429-432.

Tetzlaff, G., and Peters, M., 1986. Deep-sea sediments in the eastern equatorial Atlantic off the African coast and meteorological flow patterns over the Sahel. Geol. Rundsch., 75:71-80.

Tetzlaff, G., Peters, M., Janssen, W., and Adams, L.J., in press. Aeolian dust transport in West Africa. In Leinen, M., and Sarnthein, M. (Eds.), Paleoclimatology and Paleometeorology: Modern and Past Patterns of Global Atmospheric Transport. Proc. NATO Advanced Research Workshop.

Tetzlaff, G., and Wolter, W., 1980. Meteorological patterns and the transport of mineral dust from the North African continent. Paleoecol. Afr., 12:31-42.

Tiedemann, R., 1985. Verteilung von organischem kohlenstoff in oberflächensedimenten und die örtliche primärproduktion im äquatorialen Ostatlantik, $0-20^{\circ} \mathrm{N}, 15-25^{\circ} \mathrm{W}$ [M.S. thesis]. Univ. Kiel, Federal Republic of Germany.

van Andel, T. H., Heath, G. R., and Moore, T. C., 1975. Cenozoic history and paleoceanography of the central equatorial Pacific Ocean. Mem. Geol. Soc. Am., 143.

Date of initial receipt: 2 May 1988

Date of acceptance: 24 January 1989

Ms 108B-169 
Appendix A . Physical properties, grain sizes, and bulk mineralogy data from Site 657.

\begin{tabular}{|c|c|c|c|c|c|}
\hline $\begin{array}{l}\text { Composite } \\
\text { depth (m) }\end{array}$ & $\begin{array}{l}\text { Age } \\
\text { (m.y.) }\end{array}$ & $\begin{array}{c}\text { Dry-bulk } \\
\text { density } \\
\left(\mathrm{g} / \mathrm{cm}^{3}\right)\end{array}$ & $\begin{array}{c}\mathrm{CaCO}_{3} \\
(\%)\end{array}$ & $\begin{array}{c}\text { Siliciclastic } \\
(\%)\end{array}$ & $\begin{array}{l}\text { Quartz } \\
(\%)\end{array}$ \\
\hline 4.07 & 0.265 & 0.79 & 59.8 & 40.2 & 14 \\
\hline 5.59 & 0.363 & 1.48 & 41.9 & 58.1 & 26 \\
\hline 6.88 & 0.447 & 0.83 & 81.3 & 18.7 & 5 \\
\hline 9.86 & 0.641 & 0.86 & 59.5 & 40.5 & 15 \\
\hline 11.14 & & 1.01 & 40.8 & 59.2 & 35 \\
\hline 11.33 & & 1.01 & 28.9 & 71.1 & 25 \\
\hline 12.80 & & 0.84 & 50.6 & 49.4 & 16 \\
\hline 14.11 & Mud & 1.01 & 33.1 & 66.9 & 65 \\
\hline 14.21 & & 1.01 & 34.3 & 65.7 & 54 \\
\hline 14.95 & Flow & 0.89 & 40.4 & 59.6 & 22 \\
\hline 17.89 & & 1.13 & 34.2 & 65.8 & 57 \\
\hline 18.51 & & 0.92 & 33.3 & 66.7 & 30 \\
\hline 20.83 & & 0.87 & 37.9 & 62.1 & 19 \\
\hline 23.77 & 0.704 & 1.37 & 41.5 & 58.5 & 54 \\
\hline 25.87 & 0.738 & 1.47 & 40.3 & 59.7 & 45 \\
\hline 27.40 & 0.763 & 1.07 & 74.1 & 25.9 & 5 \\
\hline 28.20 & 0.773 & 1.06 & 27.4 & 72.6 & 58 \\
\hline 31.84 & 0.835 & 0.97 & 31.1 & 68.9 & 29 \\
\hline 33.33 & 0.859 & 1.16 & 54.3 & 45.7 & 9 \\
\hline 33.96 & 0.870 & 0.97 & 63.5 & 36.5 & 21 \\
\hline 36.90 & 0.917 & 0.96 & 37.3 & 62.7 & 20 \\
\hline 38.40 & 0.942 & 0.92 & 69.1 & 30.9 & 10 \\
\hline 39.90 & 0.966 & 1.05 & 47.9 & 52.1 & 17 \\
\hline 41.40 & 0.990 & 1.05 & 70.9 & 29.1 & 3 \\
\hline 42.04 & 1.001 & 1.05 & 50.8 & 49.2 & 18 \\
\hline 46.38 & 1.215 & 1.01 & 86.0 & 14.0 & 3 \\
\hline 47.02 & 1.247 & 0.95 & 61.1 & 38.9 & 11 \\
\hline 50.79 & 1.432 & 0.97 & 64.6 & 35.4 & 12 \\
\hline 51.41 & 1.462 & 1.03 & 76.6 & 23.4 & 10 \\
\hline 53.73 & 1.576 & 1.04 & 66.2 & 33.8 & 14 \\
\hline 54.36 & 1.607 & 1.08 & 76.6 & 23.4 & 10 \\
\hline 55.90 & 1.683 & 0.93 & 57.1 & 42.9 & 20 \\
\hline 57.40 & 1.756 & 1.03 & 56.5 & 43.5 & 11 \\
\hline 58.90 & 1.830 & 1.23 & 62.5 & 37.5 & 9 \\
\hline 60.49 & 1.908 & 1.29 & 70.6 & 29.4 & 4 \\
\hline 63.40 & 2.051 & 1.17 & 56.1 & 43.9 & 12 \\
\hline 70.54 & 2.402 & 1.10 & 76.0 & 24.0 & 3 \\
\hline 74.90 & 2.616 & 1.18 & 67.9 & 32.1 & 7 \\
\hline 77.90 & 2.764 & 1.43 & 67.5 & 32.5 & 2 \\
\hline 81.54 & 2.942 & 1.18 & 74.3 & 25.7 & 3 \\
\hline 84.40 & 3.083 & 1.20 & 75.9 & 24.1 & 5 \\
\hline 87.40 & 3.230 & 1.15 & 72.3 & 27.7 & 2 \\
\hline 89.13 & 3.315 & 1.19 & 20.3 & 79.7 & 30 \\
\hline 91.90 & 3.451 & 1.09 & 74.0 & 26.0 & 5 \\
\hline 93.90 & 3.549 & 1.07 & 77.2 & 22.8 & 4 \\
\hline 97.59 & 3.731 & 1.08 & 80.9 & 19.1 & 4 \\
\hline 122.40 & 3.874 & 1.29 & 76.0 & 24.0 & 9 \\
\hline 126.04 & 3.986 & 1.30 & 58.7 & 41.3 & 15 \\
\hline 131.90 & 4.166 & 1.39 & 70.1 & 29.9 & 14 \\
\hline 133.40 & 4.212 & 1.26 & 82.3 & 17.7 & 4 \\
\hline 136.40 & 4.305 & 1.35 & 42.5 & 57.5 & 21 \\
\hline 137.01 & 4.323 & 1.25 & 73.1 & 26.9 & 6 \\
\hline 144.40 & 4.551 & 1.19 & 80.4 & 19.6 & 6 \\
\hline 145.90 & 4.597 & 1.34 & 50.4 & 49.6 & 29 \\
\hline 147.40 & 6.340 & 1.25 & 27.0 & 73.0 & 27 \\
\hline 149.38 & 6.538 & 1.41 & 9.8 & 90.2 & 28 \\
\hline
\end{tabular}


Appendix B . Physical properties, grain sizes, and bulk mineralogy data from Site 658.

\begin{tabular}{|c|c|c|c|c|c|c|c|c|}
\hline $\begin{array}{l}\text { Composite } \\
\text { depth (m) }\end{array}$ & $\begin{array}{l}\text { Age } \\
\text { (m.y.) }\end{array}$ & $\begin{array}{c}\text { Dry-bulk } \\
\text { density } \\
\left(\mathrm{g} / \mathrm{cm}^{3}\right)\end{array}$ & $\begin{array}{c}\mathrm{CaCO}_{3} \\
(\%)\end{array}$ & $\begin{array}{c}{ }^{\mathrm{a}} \text { Opal } \\
(\%)\end{array}$ & $\begin{array}{c}\text { Siliciclastic } \\
(\%)\end{array}$ & $\begin{array}{l}\text { Quartz } \\
(\%)\end{array}$ & $\begin{array}{l}{ }^{\mathrm{b}} \text { Clay } \\
<2 \\
\mu \mathrm{m} \\
(\%)\end{array}$ & $\begin{array}{c}{ }^{\mathrm{c}} \text { Modal } \\
\text { grain } \\
\text { size } \\
(\mu \mathrm{m})\end{array}$ \\
\hline 0.83 & 0.0041 & 0.78 & 34.6 & 4.3 & 62.8 & & 65.9 & 14 \\
\hline 1.13 & 0.0055 & 0.68 & 49.3 & 8.6 & 48.6 & & 56.5 & 7 \\
\hline 1.30 & 0.0064 & 0.70 & 57.5 & & 40.8 & 9 & & \\
\hline 2.33 & 0.0114 & 0.79 & 46.0 & & 51.9 & & & \\
\hline 2.61 & 0.0128 & 0.71 & 40.8 & 2.2 & 57.6 & & 25.7 & 36 \\
\hline 2.75 & 0.0134 & 0.83 & 39.3 & & 59.6 & 43 & & \\
\hline 3.42 & 0.0164 & 1.00 & 36.4 & & 62.6 & & & \\
\hline 3.68 & 0.0174 & 1.07 & 35.6 & & 62.9 & & & \\
\hline 3.95 & 0.0185 & 0.78 & 35.9 & 0.8 & 62.6 & & 25.9 & 29 \\
\hline 4.10 & 0.0190 & 0.81 & 37.7 & & 61.4 & 37 & & \\
\hline 4.67 & 0.0213 & 0.85 & 39.0 & & 59.7 & 50 & & \\
\hline 4.77 & 0.0217 & 0.85 & 44.0 & & 54.3 & & & \\
\hline 5.04 & 0.0227 & 0.84 & 42.7 & & 55.1 & & & \\
\hline 5.12 & 0.0230 & 0.97 & 36.8 & & 61.7 & & & \\
\hline 5.84 & 0.0259 & 0.86 & 35.5 & & 62.7 & & & \\
\hline 6.13 & 0.0270 & 0.91 & 44.3 & 2.0 & 53.9 & & 31.6 & 29 \\
\hline 7.33 & 0.0373 & 0.78 & 41.8 & & 55.6 & & & \\
\hline 7.63 & 0.0399 & 0.72 & 52.2 & 6.9 & 44.5 & & 37.3 & 26 \\
\hline 8.54 & 0.0477 & 0.78 & 48.1 & & 49.3 & & & \\
\hline 8.83 & 0.0502 & 0.83 & 46.8 & 6.0 & 50.0 & & 44.8 & 29 \\
\hline 9.69 & 0.0792 & 0.91 & 52.4 & 6.4 & 45.2 & & 49.4 & 22 \\
\hline 9.75 & 0.0797 & 0.82 & 52.0 & & 45.6 & & & \\
\hline 10.84 & 0.0886 & 0.75 & 53.9 & & 43.5 & & & \\
\hline 11.13 & 0.0909 & 0.83 & 48.8 & 4.4 & 48.9 & & 36.8 & 27 \\
\hline 12.34 & 0.0975 & 0.80 & 38.1 & & 59.3 & & & \\
\hline 13.38 & 0.1031 & 0.93 & 50.7 & & 47.1 & & & \\
\hline 13.55 & 0.1040 & 0.82 & 52.8 & & 45.1 & 16 & & \\
\hline 14.26 & 0.1079 & 0.87 & 45.5 & & 52.7 & & & \\
\hline 14.88 & 0.1115 & 0.91 & 44.8 & 4.8 & 52.8 & & 40.4 & 20 \\
\hline 15.75 & 0.1186 & 0.84 & 54.0 & & 44.4 & & & \\
\hline 16.38 & 0.1238 & 0.79 & 55.4 & 7.8 & 43.2 & & 41.2 & \\
\hline 16.55 & 0.1249 & 0.73 & 48.3 & & 50.3 & 13 & & \\
\hline 16.81 & 0.1265 & 0.78 & 44.5 & & 53.1 & & & \\
\hline 17.18 & 0.1289 & 0.89 & 37.7 & & 59.9 & & & \\
\hline 17.87 & 0.1333 & 1.01 & 37.2 & 1.6 & 61.5 & & 23.0 & 32 \\
\hline 18.05 & 0.1344 & 0.92 & 41.2 & & 57.6 & 47 & & \\
\hline 19.38 & 0.1423 & 1.25 & 32.2 & 0.7 & 67.1 & & 16.3 & 38 \\
\hline 19.55 & 0.1437 & 0.97 & 33.9 & & 65.2 & & & \\
\hline 19.76 & 0.1455 & 0.95 & 39.4 & & 58.1 & & & \\
\hline 20.19 & 0.1492 & 0.91 & 36.4 & & 62.0 & 48 & & \\
\hline 20.88 & 0.1559 & 0.89 & 52.4 & 4.4 & 44.7 & & 42.8 & 25 \\
\hline 21.13 & 0.1586 & 0.93 & 43.3 & 5.1 & 54.8 & & & \\
\hline 22.58 & 0.1744 & 0.85 & 41.5 & & 56.6 & & & \\
\hline 22.68 & 0.1755 & 0.98 & 44.8 & 1.8 & 53.5 & & 29.0 & 32 \\
\hline 23.05 & 0.1795 & 0.86 & 48.4 & & 49.7 & 48 & & \\
\hline 23.99 & 0.1871 & 0.98 & 44.0 & & 53.1 & & & \\
\hline 24.29 & 0.1891 & 0.80 & 36.1 & 8.1 & 59.6 & & 53.7 & 24 \\
\hline 24.46 & 0.1902 & 0.80 & 35.9 & & 61.7 & 52 & & \\
\hline 25.49 & 0.1985 & 0.88 & 28.4 & 4.2 & 69.2 & & 65.0 & 17 \\
\hline 25.79 & 0.2012 & 0.92 & 35.5 & & 61.7 & & & \\
\hline 25.96 & 0.2026 & 0.84 & 34.4 & & 62.8 & 13 & & \\
\hline 26.99 & 0.2109 & 0.78 & 34.4 & 7.6 & 62.1 & & & \\
\hline 27.29 & 0.2134 & 0.83 & 39.7 & 6.7 & 56.8 & & 52.4 & 28 \\
\hline 27.46 & 0.2147 & 0.79 & 33.6 & 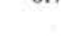 & 62.7 & 30 & & \\
\hline 28.49 & 0.2191 & 0.89 & 43.8 & & 53.3 & & & \\
\hline 28.79 & 0.2203 & 0.88 & 44.8 & 11.5 & 51.8 & & 61.8 & 13 \\
\hline 28.96 & 0.2209 & 0.87 & 45.1 & & 52.0 & 24 & & \\
\hline 29.67 & 0.2237 & 1.02 & 42.6 & & 55.1 & & & \\
\hline 29.98 & 0.2249 & 1.08 & 47.1 & & 50.8 & & & \\
\hline 30.29 & 0.2262 & 0.93 & 44.1 & 3.4 & 54.1 & & 35.6 & 32 \\
\hline 30.46 & 0.2269 & 0.83 & 40.4 & & 58.1 & 36 & & \\
\hline 32.08 & 0.2338 & 0.99 & 30.0 & & 67.2 & & & \\
\hline 32.19 & 0.2343 & 0.83 & 45.8 & & 51.8 & 14 & & \\
\hline 32.38 & 0.2351 & 0.84 & 42.0 & 10.2 & 55.0 & & 68.7 & 22 \\
\hline 33.26 & 0.2388 & 0.75 & 22.1 & & 68.7 & & & \\
\hline 33.57 & 0.2402 & 0.72 & 30.2 & 28.2 & 59.9 & & 46.3 & 31 \\
\hline 33.88 & 0.2417 & 0.83 & 39.0 & 12.5 & 56.3 & & 43.9 & 29 \\
\hline 34.05 & 0.2425 & 0.93 & 41.4 & & 54.9 & 40 & & \\
\hline 35.08 & 0.2475 & 0.99 & 39.7 & & 57.8 & & & \\
\hline 35.38 & 0.2490 & 1.01 & 43.0 & 5.2 & 54.5 & & 37.8 & 29 \\
\hline 35.55 & 0.2501 & 0.99 & 35.2 & & 62.8 & 46 & & \\
\hline 36.58 & 0.2570 & 1.10 & 40.1 & 5.1 & 57.8 & & & \\
\hline 36.88 & 0.2599 & 0.98 & 41.1 & & 56.9 & & & \\
\hline 37.05 & 0.2615 & 0.95 & 41.4 & & 57.2 & & & \\
\hline 37.76 & 0.2677 & 0.98 & 25.4 & & 71.5 & & & \\
\hline
\end{tabular}


Appendix B (continued).

\begin{tabular}{|c|c|c|c|c|c|c|c|c|}
\hline $\begin{array}{l}\text { Composite } \\
\text { depth }(m)\end{array}$ & $\begin{array}{l}\text { Age } \\
\text { (m.y.) }\end{array}$ & $\begin{array}{c}\text { Dry-bulk } \\
\text { density } \\
\left(\mathrm{g} / \mathrm{cm}^{3}\right)\end{array}$ & $\begin{array}{c}\mathrm{CaCO}_{3} \\
(\%)\end{array}$ & $\begin{array}{l}{ }^{\mathrm{a}} \mathrm{Opal} \\
(\%)\end{array}$ & $\begin{array}{c}\text { Siliciclastic } \\
(\%)\end{array}$ & $\begin{array}{c}\text { Quartz } \\
(\%)\end{array}$ & $\begin{array}{l}{ }^{\mathrm{b}} \text { Clay } \\
<2 \\
\mu \mathrm{m} \\
(\%)\end{array}$ & $\begin{array}{c}{ }^{\mathrm{c}} \text { Modal } \\
\text { grain } \\
\text { size } \\
(\mu \mathrm{m})\end{array}$ \\
\hline 38.08 & 0.2701 & 0.99 & 45.0 & & 53.3 & & & \\
\hline 38.38 & 0.2724 & 1.00 & 42.5 & 1.1 & 56.3 & & 26.7 & 36 \\
\hline 38.55 & 0.2737 & 0.95 & 48.0 & & 50.8 & 24 & & \\
\hline 39.57 & 0.2814 & 0.97 & 49.9 & & 46.7 & & & \\
\hline 39.88 & 0.2838 & 0.86 & 48.5 & 14.6 & 47.5 & & 51.4 & 7 \\
\hline 40.05 & 0.2851 & 0.76 & 56.0 & & 40.7 & 12 & & \\
\hline 40.62 & 0.2891 & 0.98 & 57.0 & & 39.7 & & & \\
\hline 40.69 & 0.2895 & 0.94 & 63.5 & & 33.5 & 11 & & \\
\hline 40.80 & 0.2900 & 0.93 & 59.6 & 17.3 & 36.9 & & 53.1 & 22 \\
\hline 41.57 & 0.2939 & 0.92 & 46.2 & & 51.5 & & & \\
\hline 41.69 & 0.2945 & 0.92 & 52.9 & & 44.7 & 15 & & \\
\hline 41.88 & 0.2954 & 0.82 & 44.5 & 2.6 & 53.9 & & 33.4 & 21 \\
\hline 42.76 & 0.2999 & 0.83 & 48.2 & & 48.6 & & & \\
\hline 43.07 & 0.3014 & 0.84 & 46.4 & 4.9 & 51.4 & & 49.4 & 28 \\
\hline 43.34 & 0.3028 & 0.94 & 25.5 & 4.5 & 72.1 & & 38.9 & 25 \\
\hline 43.51 & 0.3037 & 0.93 & 31.9 & & 65.8 & 30 & & \\
\hline 44.22 & 0.3072 & 0.96 & 48.7 & & 48.7 & & & \\
\hline 44.54 & 0.3088 & 0.98 & 39.4 & & 58.3 & & & \\
\hline 44.84 & 0.3104 & 0.95 & 40.8 & 2.5 & 57.4 & & 41.0 & 19 \\
\hline 45.01 & 0.3113 & 0.95 & 47.9 & & 50.7 & 14 & & \\
\hline 46.04 & 0.3167 & 0.90 & 43.2 & & 54.1 & & & \\
\hline 46.35 & 0.3183 & 0.90 & 43.6 & 4.3 & 53.7 & & 54.8 & 27 \\
\hline 46.52 & 0.3192 & 0.91 & 40.4 & & 55.9 & 23 & & \\
\hline 47.55 & 0.3247 & 0.91 & 43.2 & & 43.6 & & & \\
\hline 47.85 & 0.3263 & 0.65 & 31.4 & 68.7 & 53.2 & & & \\
\hline 48.02 & 0.3272 & 0.50 & 56.0 & & 29.8 & 21 & & \\
\hline 48.66 & 0.3305 & 0.51 & 25.8 & & 62.0 & 30 & & \\
\hline 49.04 & 0.3322 & 0.56 & 21.7 & 48.5 & 67.6 & & 77.0 & 27 \\
\hline 49.31 & 0.3334 & 0.62 & 29.5 & 35.4 & 59.3 & & 59.4 & 24 \\
\hline 49.77 & 0.3353 & 0.93 & 40.0 & & 51.3 & & & \\
\hline 49.94 & 0.3360 & 0.81 & 43.9 & & 48.0 & & & \\
\hline 51.07 & 0.3408 & 1.12 & 43.8 & 3.5 & 54.3 & & 35.7 & 33 \\
\hline 51.38 & 0.3425 & 0.90 & 48.6 & & 49.4 & & & \\
\hline 51.55 & 0.3435 & 0.94 & 45.5 & & 52.8 & 32 & & \\
\hline 52.57 & 0.3495 & 1.07 & 41.7 & & 56.6 & & & \\
\hline 52.88 & 0.3513 & 0.98 & 37.1 & 2.9 & 61.1 & & 25.2 & 33 \\
\hline 53.05 & 0.3523 & 0.96 & 37.0 & & 61.6 & 37 & & \\
\hline 54.07 & 0.3583 & 1.03 & 43.5 & & 54.2 & & & \\
\hline 54.38 & 0.3601 & 1.01 & 34.4 & 2.4 & 64.0 & & 33.4 & 28 \\
\hline 54.55 & 0.3611 & 0.93 & 53.3 & & 45.1 & 21 & & \\
\hline 55.26 & 0.3653 & 0.96 & 56.7 & & 40.9 & & & \\
\hline 55.57 & 0.3671 & 0.97 & 55.2 & & 42.3 & & & \\
\hline 55.88 & 0.3693 & 0.93 & 55.5 & 7.8 & 42.5 & & 48.7 & 27 \\
\hline 56.05 & 0.3707 & 0.95 & 47.0 & & 51.6 & 20 & & \\
\hline 56.64 & 0.3757 & 0.89 & 57.6 & 9.1 & 39.8 & & 51.9 & 18 \\
\hline 60.57 & 0.4049 & 1.01 & 51.5 & 4.7 & 47.0 & & 76.7 & 13 \\
\hline 60.88 & 0.4079 & 0.99 & 52.7 & 11.2 & 44.9 & & 75.6 & 20 \\
\hline 61.05 & 0.4096 & 0.91 & 42.2 & & 54.9 & 54 & & \\
\hline 61.76 & 0.4165 & 0.99 & 56.8 & & 38.5 & & & \\
\hline 62.08 & 0.4196 & 1.02 & 47.4 & & 47.4 & & & \\
\hline 62.38 & 0.4229 & 0.86 & 45.2 & 33.8 & 48.8 & & 69.0 & 22 \\
\hline 62.53 & 0.4238 & 0.82 & 49.8 & & 44.2 & 12 & & \\
\hline 62.80 & 0.4260 & 0.76 & 39.6 & & 52.7 & & & \\
\hline 63.12 & 0.4278 & 0.75 & 37.1 & 31.2 & 53.4 & & 40.7 & 34 \\
\hline 63.41 & 0.4295 & 0.77 & 33.1 & & 60.6 & & & \\
\hline 63.57 & 0.4304 & 1.04 & 32.9 & & 62.4 & & & \\
\hline 63.75 & 0.4315 & 1.05 & 32.9 & & 64.3 & & & \\
\hline 63.88 & 0.4322 & 1.14 & 28.4 & 2.6 & 70.1 & & 20.1 & 36 \\
\hline 64.00 & 0.4329 & 1.01 & 41.0 & & 57.7 & 45 & & \\
\hline 64.19 & 0.4340 & 1.09 & 39.1 & & 59.2 & & & \\
\hline 64.76 & 0.4390 & 1.12 & 30.5 & & 68.3 & & & \\
\hline 65.08 & 0.4418 & 1.14 & 34.8 & & 63.6 & & & \\
\hline 65.38 & 0.4444 & 0.97 & 46.8 & & 52.6 & & & \\
\hline 65.55 & 0.4459 & 0.89 & 57.6 & & 40.9 & 9 & & \\
\hline 66.26 & 0.4521 & 0.99 & 49.9 & & 48.8 & & & \\
\hline 66.58 & 0.4549 & 1.04 & 44.4 & & 54.2 & & & \\
\hline 66.88 & 0.4575 & 1.17 & 27.5 & 0.9 & 71.8 & & 22.3 & 33 \\
\hline 67.05 & 0.4590 & 0.97 & 50.0 & & 48.9 & 21 & & \\
\hline 67.76 & 0.4652 & 0.98 & 55.8 & & 42.7 & & & \\
\hline 68.07 & 0.4679 & 0.99 & 58.7 & & 39.1 & & & \\
\hline 68.16 & 0.4686 & 0.89 & 68.0 & & 30.4 & 4 & & \\
\hline 68.38 & 0.4706 & 0.95 & 57.4 & 8.6 & 40.2 & & 55.2 & 25 \\
\hline 70.07 & 0.4804 & 1.06 & 37.0 & 3.7 & 61.5 & & & \\
\hline 70.32 & 0.4817 & 0.92 & 34.3 & 1.8 & 64.2 & & 43.0 & 27 \\
\hline 70.49 & 0.4826 & 0.88 & 54.9 & & 43.0 & 14 & & \\
\hline
\end{tabular}


Appendix B (continued).

\begin{tabular}{|c|c|c|c|c|c|c|c|c|}
\hline $\begin{array}{l}\text { Composite } \\
\text { depth (m) }\end{array}$ & $\begin{array}{l}\text { Age } \\
\text { (m.y.) }\end{array}$ & $\begin{array}{l}\text { Dry-bulk } \\
\text { density } \\
\left(\mathrm{g} / \mathrm{cm}^{3}\right)\end{array}$ & $\begin{array}{c}\mathrm{CaCO}_{3} \\
(\%)\end{array}$ & $\begin{array}{l}{ }^{\mathrm{a} O p a l} \\
(\%)\end{array}$ & $\begin{array}{c}\text { Siliciclastic } \\
(\%)\end{array}$ & $\begin{array}{c}\text { Quartz } \\
(\%)\end{array}$ & $\begin{array}{c}{ }^{\text {b Clay }} \\
<2 \\
\mu \mathrm{m} \\
(\%)\end{array}$ & $\begin{array}{c}{ }^{\mathrm{c}_{\text {Modal }}} \\
\text { grain } \\
\text { size } \\
(\mu \mathrm{m})\end{array}$ \\
\hline 71.33 & 0.4870 & 1.12 & 33.6 & & 64.5 & & & \\
\hline 71.79 & 0.4894 & 0.93 & 53.2 & 13.3 & 44.3 & & 56.5 & 17 \\
\hline 71.83 & 0.4896 & 0.88 & 62.6 & & 35.3 & 10 & & \\
\hline 72.71 & 0.4942 & 1.04 & 50.0 & & 47.3 & & & \\
\hline 72.84 & 0.4949 & 0.96 & 52.9 & & 44.3 & 12 & & \\
\hline 73.16 & 0.4965 & 0.91 & 49.6 & 11.8 & 47.6 & & 64.4 & 16 \\
\hline 73.59 & 0.4988 & 0.99 & 44.6 & & 50.4 & & & \\
\hline 73.90 & 0.5004 & 1.05 & 48.2 & & 47.4 & & & \\
\hline 74.37 & 0.5028 & 0.93 & 41.3 & 11.4 & 54.2 & & 41.7 & 28 \\
\hline 74.38 & 0.5029 & 0.91 & 44.2 & & 51.4 & 25 & & \\
\hline 75.40 & 0.5082 & 1.04 & 49.0 & & 45.9 & & & \\
\hline 75.87 & 0.5106 & 0.91 & 48.3 & 26.2 & 46.3 & & 59.4 & 22 \\
\hline 75.88 & 0.5107 & 0.84 & 52.0 & & 42.9 & 21 & & \\
\hline 76.91 & 0.5159 & 1.04 & 40.5 & 21.9 & 54.7 & & & \\
\hline 77.21 & 0.5173 & 0.97 & 45.9 & 13.6 & 49.5 & & 44.8 & 29 \\
\hline 77.38 & 0.5182 & 0.85 & 48.2 & & 47.4 & 47 & & \\
\hline 79.26 & 0.5274 & 0.96 & 45.2 & & 49.8 & & & \\
\hline 79.57 & 0.5289 & 0.98 & 54.2 & 26.2 & 41.1 & & 56.2 & 26 \\
\hline 79.90 & 0.5305 & 0.98 & 52.2 & 26.4 & 43.2 & & 55.8 & 16 \\
\hline 80.05 & 0.5313 & 0.88 & 60.5 & & 35.5 & 14 & & \\
\hline 80.25 & 0.5322 & 0.91 & 52.6 & & 43.0 & & & \\
\hline 80.76 & 0.5347 & 0.98 & 31.7 & & 64.8 & & & \\
\hline 81.07 & 0.5362 & 1.03 & 54.1 & 5.9 & 43.3 & & 41.2 & 28 \\
\hline 81.38 & 0.5378 & 0.98 & 45.8 & 7.8 & 51.5 & & 33.3 & 28 \\
\hline 81.55 & 0.5391 & 0.90 & 56.2 & & 41.3 & 17 & & \\
\hline 82.26 & 0.5459 & 1.00 & 47.3 & & 49.6 & & & \\
\hline 82.57 & 0.5488 & 1.04 & 41.6 & & 55.4 & & & \\
\hline 82.88 & 0.5517 & 1.07 & 31.8 & & 65.3 & & & \\
\hline 83.05 & 0.5533 & 0.91 & 43.5 & & 53.4 & 41 & & \\
\hline 84.07 & 0.5630 & 1.04 & 33.8 & 5.0 & 63.4 & & 51.6 & \\
\hline 84.38 & 0.5654 & 1.00 & 30.6 & 9.3 & 65.1 & & 38.7 & 28 \\
\hline 84.55 & 0.5667 & 0.95 & 36.1 & & 59.9 & 31 & & \\
\hline 85.49 & 0.5740 & 1.11 & 19.9 & & 75.9 & & & \\
\hline 85.79 & 0.5762 & 1.03 & 25.2 & 5.7 & 71.0 & & 54.6 & 22 \\
\hline 85.94 & 0.5773 & 0.92 & 38.4 & & 58.5 & 16 & & \\
\hline 86.11 & 0.5785 & 0.92 & 44.3 & & 52.4 & & & \\
\hline 86.67 & 0.5826 & 0.94 & 50.9 & & 45.9 & 17 & & \\
\hline 86.81 & 0.5836 & 1.03 & 41.4 & 11.9 & 54.9 & & 65.4 & 7 \\
\hline 86.94 & 0.5845 & 0.88 & 37.3 & 30.4 & 54.8 & & 56.6 & 7 \\
\hline 89.04 & 0.5998 & 1.05 & 42.6 & 11.7 & 52.4 & & 42.8 & 28 \\
\hline 89.30 & 0.6016 & 0.88 & 49.3 & & 46.5 & 21 & & \\
\hline 90.58 & 0.6109 & 0.97 & 24.8 & & 70.4 & & & \\
\hline 90.69 & 0.6117 & 0.89 & 29.8 & & 65.1 & & & \\
\hline 90.80 & 0.6125 & 0.82 & 24.8 & & 69.9 & 46 & & \\
\hline 90.87 & 0.6130 & 0.78 & 26.9 & & 68.2 & 33 & & \\
\hline 90.90 & 0.6132 & 0.82 & 24.1 & 8.4 & 70.7 & & 51.8 & 27 \\
\hline 91.65 & 0.6186 & 0.99 & 17.6 & & 77.9 & & & \\
\hline 91.84 & 0.6200 & 1.03 & 28.9 & & 67.4 & 33 & & \\
\hline 91.94 & 0.6207 & 1.05 & 28.1 & & 68.0 & & & \\
\hline 92.27 & 0.6231 & 1.01 & 39.8 & & 55.9 & & & \\
\hline 92.38 & 0.6239 & 0.94 & 46.5 & & 49.3 & 22 & & \\
\hline 92.42 & 0.6242 & 0.91 & 45.8 & & 50.5 & 21 & & \\
\hline 93.37 & 0.6310 & 1.15 & 19.3 & 5.6 & 77.1 & & 23.7 & 30 \\
\hline 93.69 & 0.6352 & 1.10 & 29.7 & 5.3 & 67.0 & & 35.2 & 32 \\
\hline 93.80 & 0.6367 & 1.04 & 26.1 & & 71.5 & 33 & & \\
\hline 94.49 & 0.6459 & 1.24 & 28.0 & & 69.5 & & & \\
\hline 94.77 & 0.6496 & 1.32 & 25.9 & 2.3 & 71.8 & & 30.8 & 32 \\
\hline 95.08 & 0.6537 & 1.12 & 25.1 & & 71.2 & & & \\
\hline 95.25 & 0.6559 & 0.95 & 36.0 & & 60.9 & 55 & & \\
\hline 95.76 & 0.6627 & 0.96 & 39.4 & & 58.0 & 15 & & \\
\hline 96.16 & 0.6680 & 1.19 & 21.8 & & 74.7 & & & \\
\hline 96.41 & 0.7121 & 1.17 & 28.2 & 2.2 & 69.6 & & 22.0 & 30 \\
\hline 97.55 & 0.7210 & 1.18 & 30.5 & & 66.9 & & & \\
\hline 97.61 & 0.7215 & 1.15 & 27.4 & & 70.1 & & & \\
\hline 98.09 & 0.7252 & 1.06 & 35.7 & & 60.8 & 23 & & \\
\hline 98.26 & 0.7265 & 1.03 & 29.7 & & 66.0 & & & \\
\hline 98.54 & 0.7287 & 0.98 & 31.6 & & 64.3 & & & \\
\hline 98.83 & 0.7310 & 1.08 & 28.7 & 11.4 & 67.1 & & 70.8 & 11 \\
\hline 99.17 & 1.5729 & 1.00 & 29.3 & & 68.5 & & & \\
\hline 99.30 & 1.5750 & 1.26 & 26.4 & 3.4 & 70.9 & & 40.7 & 30 \\
\hline 99.59 & 1.5770 & 1.09 & 26.3 & 5.8 & 70.6 & & 49.2 & \\
\hline 99.76 & 1.5781 & 0.99 & 28.1 & & 67.9 & 44 & & \\
\hline 100.18 & 1.5810 & 1.20 & 32.4 & & 64.3 & & & \\
\hline 100.40 & 1.5825 & 1.20 & 19.0 & & 77.4 & & & \\
\hline 100.69 & 1.5845 & 1.13 & 36.0 & 6.0 & 59.0 & & 63.7 & \\
\hline
\end{tabular}


Appendix B (continued).

\begin{tabular}{|c|c|c|c|c|c|c|c|c|}
\hline $\begin{array}{l}\text { Composite } \\
\text { depth (m) }\end{array}$ & $\begin{array}{l}\text { Age } \\
\text { (m.y.) }\end{array}$ & $\begin{array}{c}\text { Dry-bulk } \\
\text { density } \\
\left(\mathrm{g} / \mathrm{cm}^{3}\right)\end{array}$ & $\begin{array}{c}\mathrm{CaCO}_{3} \\
(\%)\end{array}$ & $\begin{array}{l}{ }^{\mathrm{a}} \text { Opal } \\
(\%)\end{array}$ & $\begin{array}{c}\text { Siliciclastic } \\
(\%)\end{array}$ & $\begin{array}{l}\text { Quartz } \\
(\%)\end{array}$ & $\begin{array}{c}{ }^{\mathrm{b}} \text { Clay } \\
<2 \\
\mu \mathrm{m} \\
(\%)\end{array}$ & $\begin{array}{c}{ }^{\mathrm{c}_{\text {Modal }}} \text { grain } \\
\text { size } \\
(\mu \mathrm{m})\end{array}$ \\
\hline 100.88 & 1.5857 & 1.06 & 32.6 & & 62.5 & 27 & & \\
\hline 101.90 & 1.5927 & 1.04 & 30.9 & & 65.3 & & & \\
\hline 102.20 & 1.5947 & 1.17 & 34.4 & & 62.6 & 31 & & \\
\hline 102.24 & 1.5950 & 1.21 & 29.6 & 4.9 & 67.2 & & 49.9 & \\
\hline 102.87 & 1.6010 & 1.12 & 41.8 & & 55.2 & 41 & & \\
\hline 103.42 & 1.6063 & 1.09 & 33.0 & & 63.6 & & & \\
\hline 104.43 & 1.6160 & 1.24 & 29.4 & 3.4 & 68.2 & & 46.5 & 32 \\
\hline 104.53 & 1.6167 & 1.17 & 33.8 & & 64.1 & 42 & & \\
\hline 104.74 & 1.6181 & 1.04 & 37.9 & & 59.1 & & & \\
\hline 104.91 & 1.6192 & 1.19 & 32.5 & & 65.1 & 24 & & \\
\hline 105.62 & 1.6239 & 1.05 & 22.1 & & 73.6 & & & \\
\hline 105.93 & 1.6260 & 0.99 & 27.0 & & 68.1 & & & \\
\hline 106.19 & 1.6277 & 1.10 & 22.1 & & 72.6 & & & \\
\hline 107.30 & 1.6351 & 1.08 & 40.1 & & 54.9 & 41 & & \\
\hline 107.43 & 1.6360 & 1.07 & 32.3 & 11.7 & 62.1 & & 52.5 & 28 \\
\hline 107.52 & 1.6371 & 1.12 & 25.6 & 7.3 & 69.8 & & 48.1 & \\
\hline 107.74 & 1.6397 & 0.98 & 27.0 & & 68.1 & 32 & & \\
\hline 107.94 & 1.6421 & 0.86 & 37.9 & & 57.7 & 11 & & \\
\hline 108.09 & 1.6439 & 1.00 & 32.4 & & 63.8 & & & \\
\hline 108.38 & 1.6474 & 1.12 & 29.4 & & 67.1 & & & \\
\hline 109.02 & 1.6551 & 1.00 & 28.8 & & 67.4 & & & \\
\hline 109.12 & 1.6563 & 1.08 & 24.8 & 6.4 & 71.4 & & & \\
\hline 109.24 & 1.6578 & 0.89 & 32.9 & & 62.4 & 11 & & \\
\hline 109.84 & 1.6650 & 0.97 & 29.8 & & 64.6 & & & \\
\hline 110.17 & 1.6690 & 1.02 & 35.1 & & 61.4 & & & \\
\hline 110.46 & 1.6725 & 1.12 & 29.8 & 8.7 & 66.2 & & 69.2 & \\
\hline 110.59 & 1.6740 & 1.06 & 26.8 & & 70.3 & 47 & & \\
\hline 111.34 & 1.6831 & 1.03 & 36.9 & & 59.4 & & & \\
\hline 111.67 & 1.6870 & 1.02 & 35.6 & & 61.3 & & & \\
\hline 111.96 & 1.6905 & 1.13 & 26.5 & 4.8 & 70.3 & & 55.7 & 29 \\
\hline 112.13 & 1.6926 & 1.12 & 23.3 & & 73.3 & 15 & & \\
\hline 112.92 & 1.7021 & 0.98 & 30.6 & 22.2 & 64.0 & & 76.1 & 14 \\
\hline 113.21 & 1.7056 & 1.04 & 33.0 & 16.2 & 62.0 & & 70.6 & \\
\hline 113.38 & 1.7076 & 1.02 & 37.9 & & 57.0 & 26 & & \\
\hline 114.27 & 1.7183 & 0.92 & 35.0 & & 59.3 & & & \\
\hline 114.35 & 1.7193 & 0.96 & 41.2 & & 53.4 & 12 & & \\
\hline 114.50 & 1.7211 & 1.01 & 33.9 & 22.0 & 60.3 & & 73.6 & \\
\hline 115.53 & 1.7335 & 0.97 & 30.6 & & 62.1 & & & \\
\hline 115.82 & 1.7370 & 1.05 & 35.1 & & 56.7 & & & \\
\hline 115.99 & 1.7390 & 0.93 & 44.9 & & 47.0 & 30 & & \\
\hline 116.79 & 1.7486 & 0.88 & 34.1 & 35.9 & 56.5 & & 70.5 & 16 \\
\hline 117.25 & 1.7542 & 1.15 & 22.8 & & 71.5 & & & \\
\hline 117.65 & 1.7590 & 1.38 & 14.6 & 3.4 & 82.6 & & 39.7 & 29 \\
\hline 117.83 & 1.7612 & 1.18 & 20.3 & & 75.8 & & & \\
\hline 118.04 & 1.7637 & 1.25 & 17.9 & & 79.2 & 34 & & \\
\hline 118.19 & 1.7655 & 0.93 & 31.0 & & 65.0 & 43 & & \\
\hline 118.64 & 1.7709 & 1.05 & 26.3 & & 68.0 & & & \\
\hline 118.83 & 1.7732 & 1.10 & 14.8 & & 79.7 & 36 & & \\
\hline 118.88 & 1.7738 & 1.07 & 16.5 & & 77.9 & & & \\
\hline 118.98 & 1.7750 & 1.03 & 18.7 & & 75.5 & & & \\
\hline 119.09 & 1.7763 & 0.98 & 24.7 & & 70.0 & 28 & & \\
\hline 119.63 & 1.7828 & 1.15 & 21.8 & & 72.7 & & & \\
\hline 119.84 & 1.7854 & 1.21 & 20.2 & 9.2 & 74.9 & & 55.1 & 28 \\
\hline 120.11 & 1.7886 & 1.12 & 18.1 & 10.7 & 76.8 & & 63.0 & 23 \\
\hline 120.23 & 1.7900 & 1.03 & 22.5 & & 72.6 & & & . \\
\hline 120.87 & 1.7977 & 0.88 & 33.4 & & 62.1 & 24 & & \\
\hline 121.13 & 1.8009 & 1.08 & 23.8 & & 71.6 & & & \\
\hline 121.43 & 1.8045 & 1.01 & 25.4 & & 70.1 & & & \\
\hline 122.26 & 1.8145 & 1.05 & 32.1 & & 64.3 & 37 & & \\
\hline 122.45 & 1.8168 & 1.07 & 26.9 & & 69.8 & & & \\
\hline 122.59 & 1.8184 & 1.08 & 22.4 & 3.6 & 74.3 & & 34.7 & 29 \\
\hline 122.84 & 1.8215 & 1.30 & 15.4 & 2.8 & 81.7 & & 33.3 & \\
\hline 124.01 & 1.8347 & 1.07 & 17.5 & & 76.3 & & & \\
\hline 124.14 & 1.8360 & 0.92 & 25.6 & & 68.2 & 26 & & \\
\hline 124.28 & 1.8374 & 0.92 & 19.1 & 17.6 & 74.3 & & 75.0 & 14 \\
\hline 125.10 & 1.8457 & 0.96 & 26.7 & & 67.2 & 24 & & \\
\hline 125.17 & 1.8464 & 1.01 & 23.2 & & 70.2 & & & \\
\hline 125.36 & 1.8483 & 1.15 & 20.7 & & 73.3 & & & \\
\hline 125.66 & 1.8514 & 1.05 & 20.2 & 18.6 & 73.8 & & & \\
\hline 126.69 & 1.8618 & 1.13 & 24.4 & & 71.3 & 54 & & \\
\hline 126.71 & 1.8620 & 1.38 & 31.1 & & 64.8 & & & \\
\hline 127.04 & 1.8653 & 1.16 & 24.1 & 6.9 & 70.7 & & 55.1 & 29 \\
\hline 127.19 & 1.8669 & 1.17 & 20.4 & & 74.2 & & & \\
\hline 128.21 & 1.8772 & 0.91 & 21.7 & 19.7 & 71.5 & & & \\
\hline 128.31 & 1.8782 & 0.90 & 26.0 & & 67.3 & 14 & & \\
\hline
\end{tabular}


Appendix B (continued).

\begin{tabular}{|c|c|c|c|c|c|c|c|c|}
\hline $\begin{array}{l}\text { Composite } \\
\text { depth (m) }\end{array}$ & $\begin{array}{l}\text { Age } \\
\text { (m.y.) }\end{array}$ & $\begin{array}{l}\text { Dry-bulk } \\
\text { density } \\
\left(\mathrm{g} / \mathrm{cm}^{3}\right)\end{array}$ & $\underset{(\%)}{\mathrm{CaCO}_{3}}$ & $\begin{array}{l}{ }^{\mathrm{a} O p a l} \\
(\%)\end{array}$ & $\begin{array}{c}\text { Siliciclastic } \\
(\%)\end{array}$ & $\begin{array}{l}\text { Quartz } \\
(\%)\end{array}$ & $\begin{array}{l}{ }^{\mathrm{b}} \text { Clay } \\
<2 \\
\mu \mathrm{m} \\
(\%)\end{array}$ & $\begin{array}{c}{ }^{\mathrm{c}_{\text {Modal }}} \\
\text { grain } \\
\text { size } \\
(\mu \mathrm{m})\end{array}$ \\
\hline 128.88 & 1.8840 & 0.89 & 20.5 & & 71.4 & & & \\
\hline 129.08 & 1.8860 & 0.88 & 25.3 & 24.8 & 67.0 & & & \\
\hline 129.47 & 1.8900 & 1.01 & 19.2 & & 74.1 & & & \\
\hline 129.54 & 1.8907 & 1.01 & 29.2 & & 64.8 & 27 & & \\
\hline 130.42 & 1.8996 & 0.97 & 35.4 & 8.4 & 60.7 & & 59.4 & 28 \\
\hline 130.50 & 1.9004 & 1.08 & 42.4 & & 54.3 & 41 & & \\
\hline 130.63 & 1.9017 & 1.12 & 34.2 & & 61.9 & & & \\
\hline 131.73 & 1.9128 & 1.03 & 32.1 & & 62.4 & & & \\
\hline 131.84 & 1.9140 & 1.03 & 34.7 & & 59.9 & 21 & & \\
\hline 131.99 & 1.9155 & 1.16 & 28.2 & 19.1 & 65.8 & & 74.1 & 14 \\
\hline 132.99 & 1.9256 & 1.12 & 31.5 & & 63.2 & & & \\
\hline 133.09 & 1.9266 & 1.06 & 37.3 & & 57.7 & 17 & & \\
\hline 133.28 & 1.9285 & 1.27 & 30.1 & & 64.5 & & & \\
\hline 134.00 & 1.9358 & 0.87 & 27.9 & & 67.1 & 28 & & \\
\hline 134.40 & 1.9399 & 1.18 & 25.5 & & 70.5 & & & \\
\hline 134.51 & 1.9410 & 1.25 & 20.0 & 8.3 & 75.0 & & 60.2 & 29 \\
\hline 136.01 & 1.9548 & 1.04 & 27.9 & 5.8 & 68.4 & & 44.1 & 28 \\
\hline 136.07 & 1.9554 & 1.21 & 28.3 & & 68.1 & & & \\
\hline 136.45 & 1.9589 & 1.20 & 9.5 & & 82.8 & & & \\
\hline 136.65 & 1.9607 & 1.02 & 13.8 & & 76.8 & & & \\
\hline 136.75 & 1.9617 & 0.93 & 11.9 & 23.1 & 78.3 & & 73.3 & 17 \\
\hline 137.87 & 1.9720 & 1.17 & 21.4 & & 69.9 & & & \\
\hline 138.18 & 1.9749 & 1.07 & 16.1 & & 74.6 & & & \\
\hline 138.35 & 1.9764 & 0.90 & 22.3 & & 68.5 & 30 & & \\
\hline 139.06 & 1.9830 & 1.02 & 21.6 & & 69.5 & & & \\
\hline 139.37 & 1.9858 & 1.07 & 18.4 & & 73.1 & & & \\
\hline 139.68 & 1.9887 & 1.10 & 28.7 & 16.8 & 63.3 & & 57.0 & \\
\hline 140.36 & 1.9950 & 1.07 & 34.6 & & 59.1 & & & \\
\hline 140.87 & 1.9997 & 1.04 & 21.7 & & 72.1 & & & \\
\hline 141.18 & 2.0025 & 1.11 & 19.2 & 10.9 & 75.1 & & 63.5 & 24 \\
\hline 141.35 & 2.0041 & 1.06 & 23.6 & & 70.3 & 24 & & \\
\hline 142.06 & 2.0107 & 1.07 & 27.6 & & 64.3 & & & \\
\hline 142.37 & 2.0135 & 1.08 & 25.3 & & 66.4 & & & \\
\hline 142.68 & 2.0164 & 1.14 & 27.2 & 30.6 & 63.9 & & & \\
\hline 143.83 & 2.0270 & 1.26 & 27.3 & 9.2 & 67.9 & & 43.4 & 28 \\
\hline 144.14 & 2.0313 & 1.29 & 33.5 & 5.2 & 63.6 & & 42.1 & \\
\hline 145.02 & 2.0437 & 1.20 & 27.3 & & 66.9 & & & \\
\hline 145.33 & 2.0480 & 1.17 & 27.0 & 14.3 & 67.5 & & & \\
\hline 145.40 & 2.0490 & 0.99 & 28.9 & & 64.7 & & & \\
\hline 145.76 & 2.0540 & 1.00 & 32.9 & & 59.5 & & & \\
\hline 146.07 & 2.0584 & 1.00 & 33.2 & 26.1 & 60.3 & & 74.9 & 16 \\
\hline 146.30 & 2.0616 & 0.96 & 27.4 & 34.5 & 62.7 & & 77.2 & 7 \\
\hline 147.11 & 2.0730 & 0.86 & 31.2 & & 59.1 & 25 & & \\
\hline 147.49 & 2.0783 & 1.10 & 29.3 & & 61.9 & & & \\
\hline 147.76 & 2.0821 & 1.02 & 31.4 & & 60.0 & & & \\
\hline 148.55 & 2.0931 & 1.04 & 42.0 & & 48.6 & & & \\
\hline 148.77 & 2.0962 & 1.05 & 26.6 & & 63.9 & & & \\
\hline 149.11 & 2.1010 & 1.17 & 22.5 & & 68.1 & & & \\
\hline 149.24 & 2.1028 & 0.97 & 27.1 & & 63.3 & 21 & & \\
\hline 150.26 & 2.1171 & 0.99 & 24.2 & & 67.3 & & & \\
\hline 150.57 & 2.1215 & 1.10 & 18.3 & 16.4 & 72.9 & & & \\
\hline 150.74 & 2.1238 & 0.95 & 16.2 & & 75.8 & 37 & & \\
\hline 151.35 & 2.1324 & 0.99 & 31.3 & & 62.5 & 18 & & \\
\hline 151.42 & 2.1334 & 1.03 & 26.0 & & 67.4 & & & \\
\hline 151.73 & 2.1377 & 1.21 & 21.4 & 14.3 & 72.6 & & 73.5 & 23 \\
\hline 151.99 & 2.1414 & 1.14 & 22.0 & 16.1 & 71.3 & & 64.9 & 19 \\
\hline 152.75 & 2.1520 & 1.19 & 30.3 & 17.9 & 63.3 & & & \\
\hline 152.77 & 2.1523 & 1.00 & 32.2 & & 61.5 & 21 & & \\
\hline 152.90 & 2.1541 & 1.13 & 32.9 & & 61.0 & & & \\
\hline 153.03 & 2.1559 & 1.25 & 49.4 & 25.8 & 45.6 & & 64.5 & 22 \\
\hline 155.50 & 2.3008 & 1.11 & 47.3 & & 47.2 & & & \\
\hline 155.77 & 2.3040 & 1.09 & 22.0 & 11.0 & 72.5 & & 49.5 & 28 \\
\hline 155.89 & 2.3054 & 1.09 & 24.4 & & 71.0 & 61 & & \\
\hline 156.11 & 2.3079 & 1.25 & 38.4 & & 56.5 & & & \\
\hline 156.52 & 2.3127 & 1.23 & 24.5 & & 70.7 & 50 & & \\
\hline 156.89 & 2.3170 & 1.22 & 16.2 & 4.4 & 80.4 & & & \\
\hline 157.05 & 2.3189 & 1.03 & 19.6 & 9.5 & 74.8 & & 39.9 & \\
\hline 157.69 & 2.3263 & 0.95 & 24.5 & & 67.1 & & & \\
\hline 157.81 & 2.3277 & 0.98 & 29.7 & & 61.6 & 20 & & \\
\hline 158.00 & 2.3299 & 1.01 & 24.4 & 34.7 & 66.2 & & & \\
\hline 158.63 & 2.3373 & 1.06 & 21.5 & & 68.7 & & & \\
\hline 158.69 & 2.3380 & 1.06 & 23.7 & 33.6 & 67.6 & & 78.8 & 29 \\
\hline 159.14 & 2.3432 & 1.04 & 24.9 & 36.2 & 66.3 & & 81.3 & 22 \\
\hline 159.31 & 2.3452 & 0.96 & 31.6 & & 60.2 & 16 & & \\
\hline 160.15 & 2.3550 & 1.21 & 27.5 & & 65.8 & & & \\
\hline
\end{tabular}


Appendix B (continued).

\begin{tabular}{|c|c|c|c|c|c|c|c|c|}
\hline $\begin{array}{l}\text { Composite } \\
\text { depth (m) }\end{array}$ & $\begin{array}{c}\text { Age } \\
\text { (m.y.) }\end{array}$ & $\begin{array}{c}\text { Dry-bulk } \\
\text { density } \\
\left(\mathrm{g} / \mathrm{cm}^{3}\right)\end{array}$ & $\begin{array}{c}\mathrm{CaCO}_{3} \\
(\%)\end{array}$ & $\begin{array}{l}{ }^{\mathrm{a}} \mathrm{Opal} \\
(\%)\end{array}$ & $\begin{array}{c}\text { Siliciclastic } \\
(\%)\end{array}$ & $\begin{array}{c}\text { Quartz } \\
(\%)\end{array}$ & $\begin{array}{l}{ }^{\mathrm{b}} \text { Clay } \\
<2 \\
\mu \mathrm{m} \\
{ }_{(\%)}\end{array}$ & $\begin{array}{c}{ }^{\mathrm{c}} \text { Modal } \\
\text { grain } \\
\text { size } \\
(\mu \mathrm{m})\end{array}$ \\
\hline 160.31 & 2.3569 & 1.03 & 31.2 & & 64.5 & & & \\
\hline 160.50 & 2.3591 & 1.18 & 26.6 & 20.1 & 67.0 & & 70.7 & 29 \\
\hline 161.04 & 2.3654 & 0.96 & 23.1 & & 70.6 & 27 & & \\
\hline 161.14 & 2.3666 & 0.98 & 16.4 & & 76.5 & & & \\
\hline 161.52 & 2.3710 & 1.04 & 17.1 & & 76.5 & & & \\
\hline 162.27 & 2.3797 & 1.19 & 21.2 & & 3.2 & & & \\
\hline 162.54 & 2.3829 & 1.25 & 27.0 & & 68.3 & & & \\
\hline 162.82 & 2.3862 & 1.06 & 36.7 & 12.9 & 59.2 & & 66.5 & 28 \\
\hline 162.97 & 2.3879 & 0.98 & 39.3 & & 57.0 & 23 & & \\
\hline 163.70 & 2.3957 & 1.03 & 33.3 & & 62.7 & & & \\
\hline 165.18 & 2.4111 & 1.14 & 29.6 & 9.6 & 66.8 & & 52.5 & 29 \\
\hline 165.46 & 2.4140 & 1.16 & 19.5 & 9.4 & 76.2 & & 59.1 & 25 \\
\hline 165.75 & 2.4170 & 0.96 & 22.9 & & 73.3 & 27 & & \\
\hline 166.44 & 2.4241 & 1.03 & 30.9 & & 64.9 & & & \\
\hline 166.77 & 2.4275 & 1.06 & 35.1 & 29.4 & 61.1 & & & \\
\hline 166.90 & 2.4289 & 1.13 & 42.2 & & 54.3 & 14 & & \\
\hline 167.08 & 2.4308 & 1.23 & 42.1 & & 54.1 & & & \\
\hline 167.86 & 2.4388 & 1.06 & 47.0 & & 50.3 & 15 & & \\
\hline 167.93 & 2.4396 & 1.09 & 43.1 & & 53.4 & & & \\
\hline 168.24 & 2.4428 & 1.21 & 42.0 & 27.3 & 55.1 & & 75.2 & 25 \\
\hline 168.55 & 2.4460 & 1.32 & 38.5 & & 58.5 & & & \\
\hline 169.45 & 2.4553 & 1.00 & 30.2 & & 66.9 & & & \\
\hline 169.64 & 2.4573 & 1.34 & 24.4 & & 73.0 & & & \\
\hline 170.21 & 2.4632 & 1.24 & 9.5 & & 86.3 & & & \\
\hline 170.30 & 2.4641 & 1.21 & 23.2 & 4.1 & 74.0 & & 49.2 & 28 \\
\hline 170.43 & 2.4655 & 1.17 & 32.3 & & 64.5 & 36 & & \\
\hline 171.07 & 2.4721 & 1.09 & 49.1 & & 44.5 & & & \\
\hline 171.62 & 2.4778 & 1.02 & 44.1 & 46.4 & 47.2 & & & \\
\hline 172.10 & 2.4828 & 0.96 & 35.4 & & 53.8 & & & \\
\hline 172.30 & 2.4849 & 0.94 & 36.9 & & 52.4 & & & \\
\hline 172.43 & 2.4862 & 0.90 & 38.2 & & 50.8 & 14 & & \\
\hline 172.57 & 2.4877 & 0.99 & 33.0 & 51.9 & 55.3 & & 74.8 & 7 \\
\hline 174.46 & 2.5073 & 0.96 & 31.2 & & 59.0 & & & \\
\hline 174.71 & 2.5099 & 0.96 & 37.0 & & 54.1 & & & \\
\hline 175.07 & 2.5136 & 0.95 & 44.5 & & 47.0 & & & \\
\hline 175.12 & 2.5141 & 1.03 & 40.2 & & 50.8 & & & \\
\hline 176.03 & 2.5236 & 1.05 & 39.2 & & 52.5 & & & \\
\hline 176.22 & 2.5255 & 1.07 & 37.0 & 41.3 & 54.7 & & 75.7 & 21 \\
\hline 176.25 & 2.5259 & 0.92 & 40.5 & & 51.3 & 17 & & \\
\hline 176.57 & 2.5292 & 0.98 & 37.9 & & 54.0 & & & \\
\hline 177.10 & 2.5347 & 1.09 & 36.2 & & 56.2 & & & \\
\hline 177.26 & 2.5363 & 1.12 & 35.7 & & 57.2 & & & \\
\hline 177.45 & 2.5383 & 1.30 & 36.5 & & 56.5 & & & \\
\hline 177.52 & 2.5390 & 1.03 & 42.6 & & 50.8 & 10 & & \\
\hline 178.18 & 2.5459 & 1.05 & 26.0 & & 66.8 & & & \\
\hline 178.36 & 2.5477 & 1.06 & 27.3 & 26.1 & 65.8 & & & \\
\hline 178.71 & 2.5514 & 1.06 & 32.4 & 35.9 & 60.3 & & & \\
\hline 178.73 & 2.5516 & 0.92 & 38.4 & & 54.4 & 16 & & \\
\hline 179.11 & 2.5555 & 0.96 & 38.5 & & 54.7 & & & \\
\hline 179.54 & 2.5600 & 1.01 & 43.8 & & 50.1 & 14 & & \\
\hline 179.60 & 2.5606 & 1.12 & 11.0 & 27.1 & 82.9 & & 74.7 & 27 \\
\hline 179.79 & 2.5626 & 1.01 & 26.6 & 37.4 & 63.0 & & & \\
\hline 180.75 & 2.5725 & 1.06 & 13.8 & & 78.5 & & & \\
\hline 181.01 & 2.5752 & 1.07 & 36.7 & & 56.3 & & & \\
\hline 181.39 & 2.5792 & 1.03 & 12.6 & 10.3 & 81.4 & & 56.4 & 29 \\
\hline 183.89 & 2.6051 & 1.08 & 30.6 & & 64.1 & & & \\
\hline 185.10 & 2.6176 & 1.15 & 18.5 & & 75.7 & & & \\
\hline 185.15 & 2.6181 & 0.90 & 19.9 & & 74.2 & 27 & & \\
\hline 185.39 & 2.6206 & 0.95 & 19.5 & & 74.5 & & & \\
\hline 185.91 & 2.6260 & 0.88 & 21.8 & & 71.6 & & & \\
\hline 185.96 & 2.6265 & 0.87 & 26.6 & 16.1 & 67.8 & & 77.3 & 28 \\
\hline 186.23 & 2.6293 & 1.07 & 25.0 & & 69.0 & & & \\
\hline 186.63 & 2.6335 & 1.10 & 29.3 & & 64.2 & & & \\
\hline 187.27 & 2.6401 & 1.15 & 32.3 & & 60.5 & & & \\
\hline 187.43 & 2.6418 & 1.17 & 35.7 & 35.0 & 57.7 & & 78.5 & 26 \\
\hline 187.75 & 2.6451 & 1.19 & 32.0 & & 60.5 & & & \\
\hline 188.59 & 2.6538 & 1.05 & 33.3 & & 56.4 & & & \\
\hline 188.75 & 2.6555 & 1.02 & 37.8 & 53.4 & 52.1 & & & \\
\hline 189.01 & 2.6582 & 1.24 & 41.3 & & 49.0 & & & \\
\hline 189.80 & 2.6664 & 1.04 & 37.5 & & 52.8 & & & \\
\hline 189.90 & 2.6674 & 1.01 & 38.3 & & 52.4 & & & \\
\hline 190.20 & 2.6705 & 0.87 & 40.9 & & 50.1 & 13 & & \\
\hline 190.25 & 2.6710 & 1.16 & 26.7 & 47.8 & 64.0 & & & \\
\hline 193.77 & 2.7075 & 0.98 & 42.3 & & 52.1 & & & \\
\hline 194.08 & 2.7108 & 1.29 & 42.7 & 37.3 & 51.8 & & 77.3 & 14 \\
\hline
\end{tabular}


Appendix B (continued).

\begin{tabular}{|c|c|c|c|c|c|c|c|c|}
\hline $\begin{array}{l}\text { Composite } \\
\text { depth (m) }\end{array}$ & $\begin{array}{c}\text { Age } \\
\text { (m.y.) }\end{array}$ & $\begin{array}{c}\text { Dry-bulk } \\
\text { density } \\
\left(\mathrm{g} / \mathrm{cm}^{3}\right)\end{array}$ & $\begin{array}{c}\mathrm{CaCO}_{3} \\
(\%)\end{array}$ & $\begin{array}{c}{ }^{\mathrm{a}} \mathrm{Opal} \\
(\%)\end{array}$ & $\begin{array}{c}\text { Siliciclastic } \\
(\%)\end{array}$ & $\underset{(\%)}{\text { Quartz }}$ & $\begin{array}{l}{ }^{\mathrm{b}} \text { Clay } \\
<2 \\
{ }_{(\%)} \mathrm{m}\end{array}$ & $\begin{array}{c}{ }^{\mathrm{C}} \text { Modal } \\
\text { grain } \\
\text { size } \\
(\mu \mathrm{m})\end{array}$ \\
\hline 194.25 & 2.7125 & 1.02 & 47.7 & & 46.9 & & & \\
\hline 194.28 & 2.7128 & 0.97 & 21.9 & & 72.9 & 28 & & \\
\hline 194.31 & 2.7131 & 0.97 & 49.1 & & 45.8 & 12 & & \\
\hline 194.79 & 2.7181 & 0.94 & 43.3 & & 50.4 & & & \\
\hline 194.89 & 2.7192 & 0.93 & 46.6 & 38.1 & 47.6 & & & \\
\hline 195.19 & 2.7223 & 1.08 & 39.8 & & 54.1 & & & \\
\hline 195.24 & 2.7228 & 0.90 & 46.4 & & 47.7 & 12 & & \\
\hline 195.97 & 2.7304 & 0.92 & 45.4 & & 47.7 & & & \\
\hline 196.07 & 2.7314 & 0.92 & 48.3 & & 45.6 & 12 & & \\
\hline 196.09 & 2.7316 & 0.95 & 45.8 & 42.1 & 48.0 & & & \\
\hline 196.33 & 2.7341 & 1.00 & 42.2 & & 51.4 & & & \\
\hline 197.00 & 2.7410 & 0.96 & 40.2 & & 52.6 & & & \\
\hline 197.35 & 2.7447 & 0.94 & 51.1 & & 42.7 & 24 & & \\
\hline 197.41 & 2.7453 & 1.01 & 46.3 & 38.8 & 47.2 & & 78.2 & 18 \\
\hline 197.87 & 2.7501 & 1.07 & 47.1 & & 46.2 & 9 & & \\
\hline 198.05 & 2.7519 & 1.02 & 40.7 & & 52.2 & & & \\
\hline 198.75 & 2.7592 & 0.92 & 34.2 & & 57.1 & 10 & & \\
\hline 198.82 & 2.7599 & 0.96 & 24.0 & & 65.9 & & & \\
\hline 198.95 & 2.7613 & 1.03 & 33.9 & 43.3 & 57.3 & & & \\
\hline 199.04 & 2.7622 & 0.91 & 37.3 & & 54.0 & & & \\
\hline 200.05 & 2.7727 & 0.86 & 40.0 & & 48.9 & & & \\
\hline 200.24 & 2.7746 & 0.86 & 41.8 & & 46.2 & & & \\
\hline 200.25 & 2.7747 & 0.86 & 39.0 & 42.0 & 49.2 & & 75.3 & 14 \\
\hline 202.69 & 2.8000 & 0.91 & 44.0 & & 48.2 & 14 & & \\
\hline 203.27 & 2.8061 & 1.08 & 44.4 & & 48.2 & & & \\
\hline 203.39 & 2.8073 & 1.11 & 28.8 & & 64.0 & & & \\
\hline 203.66 & 2.8101 & 0.98 & 36.9 & & 56.2 & 21 & & \\
\hline 204.24 & 2.8161 & 0.94 & 30.1 & & 62.5 & & & \\
\hline 204.53 & 2.8191 & 0.92 & 40.9 & & 53.9 & & & \\
\hline 204.57 & 2.8195 & 1.01 & 45.5 & & 49.0 & 12 & & \\
\hline 204.84 & 2.8223 & 1.25 & 40.3 & & 54.3 & & & \\
\hline 205.32 & 2.8273 & 0.89 & 36.7 & & 57.4 & & & \\
\hline 205.59 & 2.8301 & 0.99 & 42.0 & & 53.9 & & & \\
\hline 205.84 & 2.8327 & 1.08 & 36.1 & 11.7 & 60.5 & & 73.9 & 29 \\
\hline 205.98 & 2.8342 & 1.00 & 41.9 & & 54.8 & 17 & & \\
\hline 206.53 & 2.8399 & 1.07 & 14.9 & & 80.4 & & & \\
\hline 206.71 & 2.8417 & 1.09 & 22.7 & & 73.8 & 13 & & \\
\hline 206.77 & 2.8424 & 1.10 & 19.9 & & 76.8 & & & \\
\hline 207.10 & 2.8458 & 1.10 & 31.5 & & 65.1 & & & \\
\hline 207.66 & 2.8516 & 1.09 & 27.6 & & 66.8 & & & \\
\hline 207.84 & 2.8535 & 1.09 & 25.6 & & 69.8 & & & \\
\hline 208.01 & 2.8552 & 1.07 & 30.5 & & 64.7 & & & \\
\hline 208.12 & 2.8564 & 1.05 & 30.4 & & 65.0 & 17 & & \\
\hline 208.16 & 2.8568 & 1.40 & 28.0 & 13.6 & 67.6 & & & \\
\hline 208.87 & 2.8641 & 1.10 & 35.5 & & 61.2 & & & \\
\hline 208.99 & 2.8654 & 1.05 & 41.3 & & 55.7 & 13 & & \\
\hline 209.11 & 2.8666 & 1.28 & 42.1 & 11.1 & 55.4 & & & \\
\hline 209.28 & 2.8684 & 1.42 & 47.3 & 3.3 & 50.3 & & 47.1 & 28 \\
\hline 209.85 & 2.8743 & 1.05 & 38.0 & & 58.3 & & & \\
\hline 209.93 & 2.8751 & 1.00 & 36.8 & & 59.7 & 14 & & \\
\hline 210.44 & 2.8804 & 1.26 & 25.9 & & 69.9 & & & \\
\hline 210.89 & 2.8851 & 1.13 & 38.3 & 22.9 & 56.6 & & & \\
\hline 212.53 & 2.9021 & 1.13 & 34.9 & & 60.9 & & & \\
\hline 212.65 & 2.9033 & 1.13 & 38.3 & 13.7 & 58.2 & & 76.5 & 18 \\
\hline 212.86 & 2.9055 & 1.22 & 37.3 & & 58.8 & & & \\
\hline 212.99 & 2.9069 & 1.07 & 42.0 & & 54.3 & 14 & & \\
\hline 213.05 & 2.9075 & 1.09 & 36.5 & & 58.8 & & & \\
\hline 213.08 & 2.9078 & 1.10 & 41.5 & & 54.4 & 23 & & \\
\hline 213.95 & 2.9168 & 1.35 & 39.4 & & 55.8 & & & \\
\hline 214.25 & 2.9199 & 1.15 & 39.5 & & 55.5 & & & \\
\hline 214.42 & 2.9217 & 1.00 & 46.0 & & 50.3 & 15 & & \\
\hline 215.10 & 2.9287 & 0.97 & 39.0 & & 56.0 & & & \\
\hline 215.26 & 2.9304 & 0.96 & 40.9 & & 54.4 & 16 & & \\
\hline 215.29 & 2.9307 & 1.21 & 35.6 & & 59.8 & & & \\
\hline 215.60 & 2.9339 & 1.32 & 30.8 & & 64.4 & & & \\
\hline 216.27 & 2.9409 & 0.09 & 29.0 & & 66.1 & & & \\
\hline 216.33 & 2.9415 & 0.51 & 29.1 & & 65.9 & & & \\
\hline 216.41 & 2.9423 & 1.06 & 28.2 & & 66.9 & 29 & & \\
\hline 216.53 & 2.9436 & 1.24 & 22.9 & & 72.3 & & & \\
\hline 216.79 & 2.9463 & 1.29 & 20.1 & 9.9 & 75.1 & & & \\
\hline 217.67 & 2.9543 & 0.90 & 37.6 & & 56.3 & 12 & & \\
\hline 217.74 & 2.9549 & 0.98 & 32.3 & & 61.6 & & & \\
\hline 217.81 & 2.9555 & 1.21 & 31.7 & 35.4 & 62.1 & & & \\
\hline 217.87 & 2.9560 & 1.19 & 42.8 & & 50.7 & & & \\
\hline 218.27 & 2.9593 & 1.06 & 48.5 & & 44.3 & 13 & & \\
\hline
\end{tabular}


R. TIEDEMANN, M. SARNTHEIN, R. STEIN

Appendix B (continued).

\begin{tabular}{|c|c|c|c|c|c|c|c|c|}
\hline $\begin{array}{l}\text { Composite } \\
\text { depth (m) }\end{array}$ & $\begin{array}{l}\text { Age } \\
\text { (m.y.) }\end{array}$ & $\begin{array}{c}\text { Dry-bulk } \\
\text { density } \\
\left(\mathrm{g} / \mathrm{cm}^{3}\right)\end{array}$ & $\begin{array}{c}\mathrm{CaCO}_{3} \\
(\%)\end{array}$ & $\begin{array}{l}{ }^{\mathrm{a}} \text { Opal } \\
(\%)\end{array}$ & $\begin{array}{c}\text { Siliciclastic } \\
(\%)\end{array}$ & $\begin{array}{l}\text { Quartz } \\
(\%)\end{array}$ & $\begin{array}{l}{ }^{\mathrm{b}} \text { Clay } \\
<2 \\
\mu \mathrm{m} \\
(\%)\end{array}$ & $\begin{array}{c}{ }^{\mathrm{c}} \text { Modal } \\
\text { grain } \\
\text { size } \\
(\mu \mathrm{m})\end{array}$ \\
\hline 218.40 & 2.9604 & 1.07 & 48.0 & & 44.4 & 7 & & \\
\hline 218.46 & 2.9609 & 1.33 & 44.6 & 68.4 & 47.6 & & 85.4 & \\
\hline 218.58 & 2.9619 & 1.24 & 41.9 & 33.2 & 52.8 & & & \\
\hline 218.97 & 2.9651 & 1.02 & 44.8 & & 48.5 & 12 & & \\
\hline 219.35 & 2.9682 & 1.23 & 39.9 & 44.7 & 52.2 & & & \\
\hline 219.52 & 2.9696 & 1.23 & 39.4 & & 52.8 & & & \\
\hline 221.77 & 2.9883 & 1.31 & 42.4 & & 53.0 & 13 & & \\
\hline 222.03 & 2.9904 & 1.32 & 44.6 & & 51.1 & & & \\
\hline 222.23 & 2.9921 & 1.42 & 41.6 & & 54.1 & & & \\
\hline 222.61 & 2.9952 & 1.26 & 39.3 & & 56.4 & & & \\
\hline 222.69 & 2.9959 & 1.23 & 45.9 & 22.9 & 50.5 & & 81.5 & 14 \\
\hline 222.80 & 2.9968 & 1.08 & 49.9 & & 47.0 & 9 & & \\
\hline 222.85 & 2.9972 & 1.14 & 49.2 & & 47.6 & 13 & & \\
\hline 222.87 & 2.9974 & 1.17 & 47.8 & & 48.7 & & & \\
\hline 222.93 & 2.9979 & 1.24 & 45.1 & & 51.5 & & & \\
\hline 223.47 & 3.0024 & 1.18 & 40.5 & 13.5 & 56.9 & & 82.8 & 14 \\
\hline 223.51 & 3.0027 & 1.14 & 35.4 & & 61.6 & & & \\
\hline 223.58 & 3.0033 & 1.07 & 38.6 & & 58.8 & 6 & & \\
\hline 223.72 & 3.0044 & 1.35 & 34.4 & & 62.7 & & & \\
\hline 224.46 & 3.0106 & 1.22 & 33.8 & & 63.5 & & & \\
\hline 224.51 & 3.0110 & 1.13 & 34.0 & & 63.0 & & & \\
\hline 224.62 & 3.0119 & 0.92 & 30.9 & & 66.4 & 22 & & \\
\hline 224.64 & 3.0121 & 0.96 & 32.0 & & 65.2 & 39 & & \\
\hline 224.73 & 3.0128 & 1.15 & 27.2 & & 70.0 & & & \\
\hline 225.03 & 3.0153 & 1.10 & 28.5 & & 68.8 & 39 & & \\
\hline 225.54 & 3.0195 & 1.14 & 25.2 & & 71.9 & & & \\
\hline 226.31 & 3.0259 & 1.34 & 27.8 & 8.2 & 69.6 & & 76.6 & 27 \\
\hline 226.76 & 3.0296 & 1.08 & 39.4 & & 57.6 & 17 & & \\
\hline 226.86 & 3.0305 & 1.17 & 34.0 & & 61.9 & & & \\
\hline 226.97 & 3.0314 & 1.26 & 35.5 & & 60.9 & & & \\
\hline 227.13 & 3.0327 & 1.30 & 36.8 & 9.7 & 59.7 & & & \\
\hline 227.48 & 3.0356 & 1.12 & 42.0 & & 55.3 & 20 & & \\
\hline 227.53 & 3.0360 & 1.20 & 37.4 & & 59.4 & & & \\
\hline 227.61 & 3.0367 & 1.32 & 37.9 & & 59.3 & & & \\
\hline 227.85 & 3.0387 & 1.23 & 34.4 & & 62.8 & & & \\
\hline 228.44 & 3.0436 & 1.34 & 9.4 & & 87.5 & 39 & & \\
\hline 228.50 & 3.0441 & 1.35 & 18.1 & & 79.1 & & & \\
\hline 228.70 & 3.0457 & 1.39 & 11.4 & 3.8 & 85.8 & & & \\
\hline 228.93 & 3.0476 & 1.45 & 10.8 & & 86.1 & & & \\
\hline 229.28 & 3.0505 & 1.28 & 11.4 & & 85.2 & 36 & & \\
\hline 229.63 & 3.0534 & 1.12 & 33.6 & & 63.0 & & & \\
\hline 229.94 & 3.0560 & 1.39 & 38.3 & & 58.1 & & & \\
\hline 231.70 & 3.0706 & 1.07 & 48.9 & & 46.7 & 12 & & \\
\hline 231.74 & 3.0709 & 1.17 & 48.9 & 34.7 & 46.4 & & 80.6 & 18 \\
\hline 232.15 & 3.0743 & 1.23 & 41.1 & 13.7 & 55.7 & & & \\
\hline 232.74 & 3.0792 & 1.16 & 47.9 & & 49.3 & & & \\
\hline 232.89 & 3.0804 & 1.14 & 44.6 & 13.9 & 52.7 & & & \\
\hline 233.10 & 3.0822 & 1.28 & 46.7 & & 50.5 & & & \\
\hline 233.13 & 3.0824 & 1.24 & 49.3 & & 48.3 & 15 & & \\
\hline 233.14 & 3.0825 & 1.23 & 49.1 & & 48.4 & 6 & & \\
\hline 233.25 & 3.0834 & 1.10 & 41.4 & & 55.3 & & & \\
\hline 233.94 & 3.0891 & 1.12 & 49.4 & & 47.6 & & & \\
\hline 233.98 & 3.0895 & 1.12 & 48.6 & & 48.7 & & & \\
\hline 234.20 & 3.0913 & 1.39 & 37.9 & & 59.0 & & & \\
\hline 235.19 & 3.0995 & 1.18 & 40.0 & & 56.9 & & & \\
\hline 235.26 & 3.1001 & 1.02 & 42.6 & & 54.3 & 13 & & \\
\hline 235.33 & 3.1007 & 1.32 & 35.7 & & 60.9 & & & \\
\hline 236.07 & 3.1068 & 1.07 & 24.5 & & 71.8 & & & \\
\hline 236.35 & 3.1091 & 1.21 & 26.2 & & 69.4 & 54 & & \\
\hline 236.38 & 3.1094 & 1.23 & 38.6 & & 58.7 & & & \\
\hline 236.55 & 3.1108 & 1.13 & 21.7 & & 74.0 & 24 & & \\
\hline 237.50 & 3.1186 & 1.14 & 41.9 & & 55.6 & 12 & & \\
\hline 237.53 & 3.1189 & 1.16 & 36.5 & & 60.9 & & & \\
\hline 237.71 & 3.1204 & 1.26 & 16.6 & 6.9 & 78.9 & & 79.6 & 28 \\
\hline 238.17 & 3.1242 & 0.82 & 43.2 & & 53.7 & & & \\
\hline 238.30 & 3.1253 & 0.69 & 28.8 & & 67.9 & 45 & & \\
\hline 238.40 & 3.1261 & 1.18 & 27.7 & & 69.4 & & & \\
\hline 238.55 & 3.1273 & 1.35 & 38.3 & & 58.5 & & & \\
\hline 239.03 & 3.1313 & 1.30 & 20.9 & & 76.4 & & & \\
\hline 240.96 & 3.1473 & 1.03 & 12.5 & & 83.1 & & & \\
\hline 241.28 & 3.1500 & 0.98 & 11.3 & & 85.4 & & & \\
\hline 241.58 & 3.1525 & 1.23 & 9.0 & 2.4 & 87.6 & & 61.0 & 28 \\
\hline 241.75 & 3.1539 & 1.14 & 10.8 & & 85.9 & 49 & & \\
\hline 242.77 & 3.1623 & 1.10 & 21.2 & & 74.8 & & & \\
\hline 243.08 & 3.1649 & 1.13 & 22.5 & 12.0 & 73.3 & & & \\
\hline
\end{tabular}


Appendix B (continued).

\begin{tabular}{|c|c|c|c|c|c|c|c|c|}
\hline $\begin{array}{l}\text { Composite } \\
\text { depth }(\mathrm{m})\end{array}$ & $\begin{array}{l}\text { Age } \\
\text { (m.y.) }\end{array}$ & $\begin{array}{l}\text { Dry-bulk } \\
\text { density } \\
\left(\mathrm{g} / \mathrm{cm}^{3}\right)\end{array}$ & $\begin{array}{c}\mathrm{CaCO}_{3} \\
(\%)\end{array}$ & $\begin{array}{c}{ }^{\mathrm{a}} \mathrm{Opal} \\
(\%)\end{array}$ & $\begin{array}{c}\text { Siliciclastic } \\
(\%)\end{array}$ & $\begin{array}{c}\text { Quartz } \\
(\%)\end{array}$ & $\begin{array}{l}{ }^{\mathrm{b}} \text { Clay } \\
<2 \\
\mu \mathrm{m} \\
(\%)\end{array}$ & $\begin{array}{c}{ }^{\mathrm{c}} \text { Modal } \\
\text { grain } \\
\text { size } \\
(\mu \mathrm{m})\end{array}$ \\
\hline 243.25 & 3.1663 & 1.07 & 29.1 & & 66.9 & 16 & & \\
\hline 243.87 & 3.1714 & 1.08 & 25.7 & & 69.5 & & & \\
\hline 244.22 & 3.1743 & 1.08 & 31.3 & 12.4 & 64.8 & & 81.2 & 24 \\
\hline 244.52 & 3.1768 & 1.21 & 26.6 & & 68.8 & & & \\
\hline 244.64 & 3.1778 & 0.97 & 34.2 & & 61.8 & 38 & & \\
\hline 245.43 & 3.1844 & 1.12 & 23.9 & & 72.1 & & & \\
\hline 245.72 & 3.1868 & 1.18 & 12.2 & & 84.1 & & & \\
\hline 246.02 & 3.1893 & 1.20 & 17.8 & 5.5 & 77.5 & & 73.3 & 28 \\
\hline 246.19 & 3.1907 & 1.11 & 14.0 & & 81.6 & 37 & & \\
\hline 246.87 & 3.1963 & 1.18 & 2.2 & & 93.0 & & & \\
\hline 247.22 & 3.1992 & 1.20 & 4.3 & & 91.5 & & & \\
\hline 247.50 & 3.2015 & 1.23 & 10.4 & 5.3 & 85.0 & & & \\
\hline 247.60 & 3.2023 & 1.21 & 16.3 & & 79.2 & & & \\
\hline 247.67 & 3.2029 & 1.20 & 19.3 & & 76.5 & 25 & & \\
\hline 248.45 & 3.2094 & 1.13 & 28.8 & & 67.8 & & & \\
\hline 248.66 & 3.2111 & 1.10 & 33.1 & & 63.4 & 12 & & \\
\hline 248.77 & 3.2120 & 1.28 & 20.8 & & 75.8 & & & \\
\hline 249.11 & 3.2149 & 1.13 & 35.1 & & 61.6 & 14 & & \\
\hline 249.19 & 3.2155 & 1.14 & 27.5 & & 68.3 & & & \\
\hline 250.31 & 3.2248 & 1.23 & 13.7 & 3.8 & 83.4 & & 74.9 & 28 \\
\hline 250.72 & 3.2282 & 1.24 & 7.3 & & 88.9 & & & \\
\hline 251.15 & 3.2318 & 1.25 & 15.2 & & 82.4 & & & \\
\hline 251.31 & 3.2331 & 1.33 & 14.2 & & 83.0 & 44 & & \\
\hline 251.37 & 3.2336 & 1.40 & 13.2 & & 84.1 & & & \\
\hline 251.53 & 3.2349 & 1.22 & 10.3 & & 87.1 & 53 & & \\
\hline 252.13 & 3.2399 & 1.32 & 7.4 & & 89.3 & & & \\
\hline 252.41 & 3.2422 & 1.36 & 20.2 & & 77.3 & & & \\
\hline 252.72 & 3.2448 & 1.41 & 27.1 & & 70.5 & & & \\
\hline 252.75 & 3.2450 & 1.24 & 9.7 & & 88.0 & & & \\
\hline 253.29 & 3.2495 & 1.17 & 33.4 & & 64.0 & & & \\
\hline 253.63 & 3.2523 & 1.13 & 30.5 & 9.6 & 67.4 & & 84.6 & 6 \\
\hline 253.90 & 3.2546 & 1.37 & 37.3 & & 60.4 & 16 & & \\
\hline 253.92 & 3.2547 & 1.40 & 33.6 & 11.4 & 63.7 & & & \\
\hline 254.96 & 3.2633 & 1.33 & 24.3 & & 72.9 & 46 & & \\
\hline 255.13 & 3.2648 & 1.32 & 17.9 & & 79.6 & & & \\
\hline 255.42 & 3.2672 & 1.42 & 20.5 & & 76.8 & & & \\
\hline 256.16 & 3.2733 & 1.27 & 42.6 & & 55.5 & 21 & & \\
\hline 256.30 & 3.2744 & 1.14 & 39.6 & & 58.1 & & & \\
\hline 256.63 & 3.2772 & 1.39 & 27.8 & & 69.2 & & & \\
\hline 257.29 & 3.2827 & 1.38 & 6.8 & & 89.2 & 11 & & \\
\hline 257.59 & 3.2851 & 1.38 & 21.0 & & 76.8 & & & \\
\hline 257.88 & 3.2875 & 1.40 & 18.6 & 2.1 & 79.1 & & 63.7 & 28 \\
\hline 258.56 & 3.2932 & 1.49 & 8.8 & & 88.4 & & & \\
\hline 258.74 & 3.2947 & 1.51 & 6.8 & & 90.0 & 53 & & \\
\hline 258.76 & 3.2948 & 1.51 & 4.2 & & 92.8 & & & \\
\hline 258.85 & 3.2956 & 1.23 & 13.7 & & 83.6 & & & \\
\hline 260.05 & 3.3055 & 1.34 & 10.5 & & 87.3 & 71 & & \\
\hline 260.25 & 3.3072 & 1.31 & 15.8 & & 81.8 & & & \\
\hline 260.54 & 3.3096 & 1.47 & 31.0 & 5.4 & 66.5 & & 67.8 & 28 \\
\hline 261.63 & 3.3186 & 1.32 & 17.6 & & 79.8 & 52 & & \\
\hline 261.81 & 3.3201 & 1.31 & 13.8 & & 83.7 & & & \\
\hline 262.12 & 3.3227 & 1.41 & 28.1 & & 68.7 & & & \\
\hline 263.00 & 3.3300 & 1.19 & 28.8 & & 68.1 & 25 & & \\
\hline 263.13 & 3.3311 & 1.25 & 17.0 & & 79.9 & & & \\
\hline 263.54 & 3.3344 & 1.39 & 29.3 & 5.6 & 67.1 & & & \\
\hline 264.16 & 3.3396 & 1.32 & 25.5 & & 71.3 & & & \\
\hline 264.39 & 3.3415 & 1.29 & 14.8 & & 82.0 & & & \\
\hline 264.70 & 3.3441 & 1.36 & 15.6 & 3.1 & 80.5 & & 61.6 & 29 \\
\hline 264.86 & 3.3454 & 1.22 & 22.5 & & 73.8 & 38 & & \\
\hline 265.75 & 3.3528 & 1.32 & 17.1 & & 80.1 & & & \\
\hline 265.91 & 3.3541 & 1.33 & 27.3 & & 68.7 & & & \\
\hline 266.06 & 3.3553 & 1.35 & 23.6 & 5.7 & 72.8 & & 69.9 & 28 \\
\hline 269.74 & 3.3858 & 1.18 & 24.5 & 7.8 & 72.1 & & 83.4 & 22 \\
\hline 270.02 & 3.3881 & 1.29 & 23.2 & & 73.5 & & & \\
\hline 270.19 & 3.3896 & 1.27 & 30.4 & & 66.7 & 17 & & \\
\hline 271.19 & 3.3978 & 1.18 & 26.0 & & 71.6 & & & \\
\hline 271.52 & 3.4006 & 1.16 & 26.1 & 4.2 & 71.2 & & & \\
\hline 271.70 & 3.4021 & 1.14 & 34.2 & & 63.5 & 27 & & \\
\hline 272.28 & 3.4069 & 1.19 & 18.8 & & 77.0 & & & \\
\hline 272.41 & 3.4080 & 1.20 & 21.6 & & 74.3 & 26 & & \\
\hline 272.52 & 3.4089 & 1.30 & 15.2 & & 80.4 & & & \\
\hline 272.62 & 3.4097 & 1.40 & 15.3 & 4.2 & 80.0 & & 66.0 & 28 \\
\hline 272.87 & 3.4118 & 1.29 & 19.3 & & 76.6 & & & \\
\hline 278.36 & 3.4573 & 1.34 & 45.2 & & 53.6 & 20 & & \\
\hline 279.25 & 3.4646 & 1.35 & 14.9 & 1.4 & 84.8 & & 70.0 & 18 \\
\hline
\end{tabular}


Appendix B (continued).

\begin{tabular}{|c|c|c|c|c|c|c|c|c|}
\hline $\begin{array}{l}\text { Composite } \\
\text { depth (m) }\end{array}$ & $\begin{array}{c}\text { Age } \\
\text { (m.y.) }\end{array}$ & $\begin{array}{c}\text { Dry-bulk } \\
\text { density } \\
\left(\mathrm{g} / \mathrm{cm}^{3}\right)\end{array}$ & $\begin{array}{c}\mathrm{CaCO}_{3} \\
(\%)\end{array}$ & $\begin{array}{c}{ }^{\mathrm{a} O p a l} \\
(\%)\end{array}$ & $\begin{array}{c}\text { Siliciclastic } \\
(\%)\end{array}$ & $\begin{array}{c}\text { Quartz } \\
(\%)\end{array}$ & $\begin{array}{c}{ }^{\mathrm{b}} \text { Clay } \\
<2 \\
\mu \mathrm{m} \\
(\%)\end{array}$ & $\begin{array}{c}{ }^{\mathrm{c}} \text { Modal } \\
\text { grain } \\
\text { size } \\
(\mu \mathrm{m})\end{array}$ \\
\hline 279.50 & 3.4667 & 1.28 & 21.6 & 1.6 & 75.8 & & & \\
\hline 279.72 & 3.4685 & 1.40 & 11.9 & & 87.9 & & & \\
\hline 288.46 & 3.5410 & 1.32 & 9.8 & & 87.5 & & & \\
\hline 288.77 & 3.5435 & 1.32 & 24.6 & & 73.6 & & & \\
\hline 289.08 & 3.5461 & 1.34 & 25.4 & 2.2 & 72.8 & & & \\
\hline 289.25 & 3.5475 & 1.22 & 27.9 & & 70.4 & 19 & & \\
\hline 290.27 & 3.5560 & 1.34 & 29.4 & 2.9 & 68.9 & & 82.2 & 22 \\
\hline 290.53 & 3.5581 & 1.48 & 29.7 & & 68.4 & & & \\
\hline 290.60 & 3.5587 & 1.48 & 32.8 & & 65.7 & 19 & & \\
\hline 291.24 & 3.5640 & 1.43 & 22.4 & & 75.0 & & & \\
\hline 291.52 & 3.5663 & 1.41 & 19.3 & & 78.5 & & & \\
\hline 291.58 & 3.5668 & 1.35 & 11.5 & & 86.4 & 41 & & \\
\hline 291.83 & 3.5689 & 1.35 & 8.0 & & 89.8 & & & \\
\hline 292.02 & 3.5705 & 1.30 & 6.0 & & 91.4 & & & \\
\hline 292.51 & 3.5745 & 1.18 & 23.9 & & 74.1 & 22 & & \\
\hline 292.70 & 3.5761 & 1.30 & 28.9 & & 69.2 & & & \\
\hline 293.01 & 3.5787 & 1.36 & 36.6 & & 61.7 & & & \\
\hline
\end{tabular}

Appendix C . Physical properties, grain sizes, and bulk mineralogy data from Site 659 .

\begin{tabular}{|c|c|c|c|c|c|}
\hline $\begin{array}{l}\text { Composite } \\
\text { depth (m) }\end{array}$ & $\begin{array}{l}\text { Age } \\
\text { (m.y.) }\end{array}$ & $\begin{array}{c}\text { Dry-bulk } \\
\text { density } \\
\left(\mathrm{g} / \mathrm{cm}^{3}\right)\end{array}$ & $\begin{array}{c}\mathrm{CaCO}_{3} \\
(\%)\end{array}$ & $\begin{array}{c}\text { Siliciclastic } \\
(\%)\end{array}$ & $\begin{array}{c}\text { Quartz } \\
(\%)\end{array}$ \\
\hline 0.47 & 0.008 & 0.75 & 66.60 & 33.30 & \\
\hline 0.73 & 0.013 & 0.75 & 63.90 & 36.10 & \\
\hline 0.88 & 0.015 & 0.75 & 73.90 & 26.10 & 18 \\
\hline 1.05 & 0.018 & 0.75 & 45.37 & 54.63 & \\
\hline 1.06 & 0.019 & 0.75 & 47.33 & 52.67 & \\
\hline 1.29 & 0.023 & 0.75 & 51.45 & 48.55 & \\
\hline 1.50 & 0.026 & 0.74 & 55.79 & 44.21 & \\
\hline 1.56 & 0.028 & 0.75 & 61.80 & 38.20 & \\
\hline 1.64 & 0.031 & 0.74 & 41.40 & 58.60 & \\
\hline 2.11 & 0.051 & 0.74 & 67.04 & 32.96 & \\
\hline 2.15 & 0.052 & 0.74 & 60.90 & 39.10 & \\
\hline 2.33 & 0.060 & 0.74 & 54.20 & 45.80 & 39 \\
\hline 2.46 & 0.065 & 0.74 & 39.88 & 60.12 & \\
\hline 2.51 & 0.067 & 0.74 & 41.80 & 58.20 & \\
\hline 2.72 & 0.075 & 0.75 & 42.01 & 57.99 & \\
\hline 2.91 & 0.082 & 0.76 & 53.31 & 46.69 & \\
\hline 2.99 & 0.085 & 0.76 & 50.70 & 49.30 & \\
\hline 3.26 & 0.094 & 0.76 & 54.10 & 45.90 & \\
\hline 3.43 & 0.100 & 0.78 & 76.00 & 24.00 & \\
\hline 3.58 & 0.105 & 0.79 & 50.50 & 49.50 & 20 \\
\hline 3.61 & 0.106 & 0.78 & 45.43 & 54.57 & \\
\hline 3.62 & 0.106 & 0.78 & 48.30 & 51.70 & \\
\hline 3.85 & 0.114 & 0.78 & 41.21 & 58.79 & \\
\hline 3.93 & 0.116 & 0.78 & 54.61 & 45.39 & \\
\hline 4.16 & 0.124 & 0.76 & 67.32 & 32.68 & \\
\hline 4.41 & 0.134 & 0.75 & 53.91 & 46.09 & \\
\hline 4.43 & 0.135 & 0.74 & 53.20 & 46.80 & \\
\hline 4.73 & 0.142 & 0.74 & 52.20 & 47.80 & \\
\hline 5.12 & 0.151 & 0.73 & 44.40 & 55.60 & \\
\hline 5.15 & 0.152 & 0.70 & 46.90 & 53.10 & 52 \\
\hline 5.17 & 0.153 & 0.73 & 45.21 & 54.79 & \\
\hline 5.26 & 0.156 & 0.72 & 37.09 & 62.91 & \\
\hline 5.43 & 0.163 & 0.72 & 39.73 & 60.27 & \\
\hline 5.53 & 0.168 & 0.76 & 67.43 & 32.57 & \\
\hline 5.81 & 0.179 & 0.79 & 58.20 & 41.80 & \\
\hline 5.91 & 0.183 & 0.78 & 50.92 & 49.08 & \\
\hline 6.14 & 0.193 & 0.82 & 43.00 & 57.00 & \\
\hline 6.55 & 0.209 & 0.89 & 57.30 & 42.70 & 24 \\
\hline 6.62 & 0.211 & 0.89 & 52.90 & 47.10 & \\
\hline 6.73 & 0.216 & 0.89 & 56.52 & 43.48 & \\
\hline 6.93 & 0.225 & 0.89 & 53.91 & 46.09 & \\
\hline 7.03 & 0.228 & 0.89 & 42.03 & 57.97 & \\
\hline 7.31 & 0.237 & 0.89 & 60.50 & 39.50 & \\
\hline 7.41 & 0.240 & 0.89 & 60.99 & 39.01 & \\
\hline
\end{tabular}

Appendix C (continued).

\begin{tabular}{|c|c|c|c|c|c|}
\hline $\begin{array}{l}\text { Composite } \\
\text { depth }(m)\end{array}$ & $\begin{array}{l}\text { Age } \\
\text { (m.y.) }\end{array}$ & $\begin{array}{c}\text { Dry-bulk } \\
\text { density } \\
\left(\mathrm{g} / \mathrm{cm}^{3}\right)\end{array}$ & $\begin{array}{c}\mathrm{CaCO}_{3} \\
(\%)\end{array}$ & $\begin{array}{c}\text { Siliciclastic } \\
(\%)\end{array}$ & $\begin{array}{c}\text { Quartz } \\
(\%)\end{array}$ \\
\hline 8.12 & 0.262 & 0.88 & 51.80 & 48.20 & \\
\hline 8.34 & 0.268 & 0.89 & 58.56 & 41.44 & \\
\hline 8.91 & 0.285 & 0.87 & 45.35 & 54.65 & \\
\hline 9.10 & 0.291 & 0.86 & 62.70 & 37.30 & \\
\hline 9.23 & 0.295 & 0.86 & 71.60 & 28.40 & \\
\hline 9.30 & 0.297 & 0.87 & 47.20 & 52.80 & \\
\hline 9.36 & 0.299 & 0.88 & 66.28 & 33.72 & \\
\hline 9.45 & 0.303 & 0.89 & 71.20 & 28.80 & 14 \\
\hline 9.63 & 0.311 & 0.88 & 59.85 & 40.15 & \\
\hline 9.90 & 0.325 & 0.87 & 51.80 & 48.20 & \\
\hline 9.91 & 0.326 & 0.87 & 56.08 & 43.92 & \\
\hline 10.01 & 0.331 & 0.87 & 74.60 & 25.40 & \\
\hline 10.21 & 0.335 & 0.86 & 71.90 & 28.10 & \\
\hline 10.43 & 0.339 & 0.88 & 59.07 & 40.93 & \\
\hline 10.54 & 0.341 & 0.89 & 58.80 & 41.20 & \\
\hline 10.80 & 0.348 & 0.91 & 60.80 & 39.20 & \\
\hline 10.91 & 0.351 & 0.92 & 60.92 & 39.08 & \\
\hline 10.95 & 0.352 & 0.83 & 60.00 & 40.00 & 25 \\
\hline 11.13 & 0.357 & 0.85 & 50.15 & 49.85 & \\
\hline 11.40 & 0.364 & 0.96 & 57.90 & 42.10 & \\
\hline 11.41 & 0.365 & 0.87 & 53.06 & 46.94 & \\
\hline 11.71 & 0.373 & 0.90 & 66.50 & 33.50 & \\
\hline 11.93 & 0.379 & 0.87 & 44.34 & 55.66 & \\
\hline 12.04 & 0.382 & 0.90 & 56.60 & 43.40 & \\
\hline 12.41 & 0.392 & 0.97 & 61.40 & 38.60 & \\
\hline 12.45 & 0.393 & 0.97 & 56.90 & 43.10 & 31 \\
\hline 12.63 & 0.398 & 0.94 & 56.49 & 43.51 & \\
\hline 12.90 & 0.405 & 0.90 & 77.10 & 22.90 & \\
\hline 12.91 & 0.405 & 0.90 & 69.56 & 30.44 & \\
\hline 13.21 & 0.414 & 0.84 & 70.90 & 29.10 & \\
\hline 13.43 & 0.420 & 0.80 & 56.29 & 43.71 & \\
\hline 13.54 & 0.423 & 0.78 & 61.80 & 38.20 & \\
\hline 13.91 & 0.434 & 0.72 & 35.76 & 64.24 & \\
\hline 13.95 & 0.435 & 0.72 & 44.60 & 55.40 & 43 \\
\hline 14.13 & 0.442 & 0.74 & 62.12 & 37.88 & \\
\hline 14.40 & 0.452 & 0.75 & 54.60 & 45.40 & \\
\hline 14.41 & 0.452 & 0.77 & 54.38 & 45.62 & \\
\hline 14.71 & 0.463 & 0.82 & 42.40 & 57.60 & \\
\hline 14.93 & 0.471 & 0.84 & 43.60 & 56.40 & \\
\hline 15.04 & 0.476 & 0.86 & 56.70 & 43.30 & \\
\hline 15.30 & 0.487 & 0.89 & 51.50 & 48.50 & \\
\hline 15.41 & 0.492 & 0.91 & 52.91 & 47.09 & \\
\hline 15.85 & 0.504 & 0.91 & 78.20 & 21.80 & 9 \\
\hline 15.90 & 0.506 & 0.91 & 67.10 & 32.90 & \\
\hline
\end{tabular}


Appendix C (continued).

\begin{tabular}{|c|c|c|c|c|c|}
\hline $\begin{array}{l}\text { Composite } \\
\text { depth (m) }\end{array}$ & $\begin{array}{c}\text { Age } \\
\text { (m.y.) }\end{array}$ & $\begin{array}{c}\text { Dry-bulk } \\
\text { density } \\
\left(\mathrm{g} / \mathrm{cm}^{3}\right)\end{array}$ & $\begin{array}{c}\mathrm{CaCO}_{3} \\
(\%)\end{array}$ & $\begin{array}{c}\text { Siliciclastic } \\
(\%)\end{array}$ & $\begin{array}{c}\text { Quartz } \\
(\%)\end{array}$ \\
\hline 16.11 & 0.512 & 0.92 & 66.87 & 33.13 & \\
\hline 16.43 & 0.521 & 0.92 & 71.98 & 28.02 & \\
\hline 16.91 & 0.534 & 0.92 & 70.72 & 29.28 & \\
\hline 17.40 & 0.548 & 0.92 & 78.20 & 21.80 & \\
\hline 17.93 & 0.563 & 0.93 & 61.83 & 38.17 & \\
\hline 18.41 & 0.577 & 0.91 & 55.57 & 44.43 & \\
\hline 19.39 & 0.604 & 0.94 & 62.10 & 37.90 & 26 \\
\hline 19.53 & 0.608 & 0.93 & 35.31 & 64.69 & \\
\hline 19.83 & 0.617 & 0.92 & 45.28 & 54.72 & \\
\hline 20.11 & 0.624 & 0.90 & 66.40 & 33.60 & \\
\hline 20.34 & 0.630 & 0.89 & 55.80 & 44.20 & \\
\hline 20.85 & 0.643 & 0.86 & 55.00 & 45.00 & 30 \\
\hline 21.03 & 0.647 & 0.86 & 47.25 & 52.75 & \\
\hline 21.33 & 0.654 & 0.86 & 63.58 & 36.42 & \\
\hline 21.61 & 0.660 & 0.87 & 41.60 & 58.40 & \\
\hline 21.64 & 0.661 & 0.87 & 75.50 & 24.50 & \\
\hline 22.35 & 0.687 & 0.88 & 63.00 & 37.00 & 29 \\
\hline 22.53 & 0.695 & 0.88 & 34.43 & 65.57 & \\
\hline 22.83 & 0.701 & 0.88 & 74.15 & 25.85 & \\
\hline 23.11 & 0.706 & 0.88 & 58.10 & 41.90 & \\
\hline 23.70 & 0.718 & 0.88 & 41.70 & 58.30 & \\
\hline 23.85 & 0.721 & 0.88 & 61.70 & 38.30 & 28 \\
\hline 24.03 & 0.725 & 0.89 & 57.89 & 42.11 & \\
\hline 24.33 & 0.731 & 0.89 & 71.92 & 28.08 & \\
\hline 24.61 & 0.741 & 0.89 & 50.50 & 49.50 & \\
\hline 25.35 & 0.768 & 0.90 & 68.90 & 31.10 & 17 \\
\hline 25.53 & 0.774 & 0.90 & 65.74 & 34.26 & \\
\hline 25.83 & 0.782 & 0.90 & 65.64 & 34.36 & \\
\hline 26.11 & 0.790 & 0.91 & 58.40 & 41.60 & \\
\hline 26.85 & 0.811 & 0.91 & 41.40 & 58.60 & 42 \\
\hline 26.96 & 0.814 & 0.91 & 56.95 & 43.05 & \\
\hline 27.23 & 0.822 & 0.91 & 40.64 & 59.36 & \\
\hline 27.51 & 0.831 & 0.92 & 82.00 & 18.00 & \\
\hline 28.70 & 0.867 & 0.93 & 57.00 & 43.00 & \\
\hline 28.85 & 0.872 & 0.93 & 78.00 & 22.00 & 6 \\
\hline 29.02 & 0.877 & 0.93 & 63.00 & 37.00 & \\
\hline 29.33 & 0.886 & 0.93 & 59.41 & 40.59 & \\
\hline 29.61 & 0.895 & 0.94 & 68.90 & 31.10 & \\
\hline 30.18 & 0.912 & 0.95 & 84.10 & 15.90 & \\
\hline 30.33 & 0.917 & 0.95 & 75.90 & 24.10 & 6 \\
\hline 30.50 & 0.922 & 0.95 & 68.00 & 32.00 & \\
\hline 30.81 & 0.931 & 0.94 & 63.13 & 36.87 & \\
\hline 31.09 & 0.939 & 0.93 & 73.70 & 26.30 & \\
\hline 31.83 & 0.960 & 0.92 & 68.90 & 31.10 & 5 \\
\hline 32.00 & 0.965 & 0.92 & 52.00 & 48.00 & \\
\hline 32.31 & 0.974 & 0.91 & 48.58 & 51.42 & \\
\hline 32.59 & 0.983 & 0.90 & 60.60 & 39.40 & \\
\hline 33.33 & 1.011 & 0.88 & 50.50 & 49.50 & 34 \\
\hline 33.47 & 1.014 & 0.89 & 48.00 & 52.00 & \\
\hline 33.53 & 1.019 & 0.89 & 39.40 & 60.60 & \\
\hline 33.57 & 1.020 & 0.89 & 49.70 & 50.30 & \\
\hline 34.51 & 1.055 & 0.88 & 57.70 & 42.30 & \\
\hline 35.03 & 1.075 & 0.88 & 57.34 & 42.66 & \\
\hline 36.01 & 1.111 & 0.88 & 84.80 & 15.20 & \\
\hline 36.53 & 1.131 & 0.93 & 64.49 & 35.51 & \\
\hline 37.51 & 1.168 & 0.98 & 52.30 & 47.70 & \\
\hline 37.94 & 1.017 & 0.95 & 44.70 & 55.30 & \\
\hline 38.03 & 1.187 & 0.94 & 46.05 & 53.95 & \\
\hline 38.35 & 1.199 & 0.92 & 57.10 & 42.90 & 23 \\
\hline 38.83 & 1.217 & 0.92 & 62.92 & 37.08 & \\
\hline 39.11 & 1.228 & 0.92 & 69.80 & 30.20 & \\
\hline 39.84 & 1.255 & 0.82 & 51.30 & 48.70 & \\
\hline 39.85 & 1.255 & 0.92 & 72.60 & 27.40 & 12 \\
\hline 40.33 & 1.273 & 0.94 & 66.22 & 33.78 & \\
\hline 40.61 & 1.284 & 0.95 & 58.30 & 41.70 & \\
\hline 41.31 & 1.310 & 0.83 & 61.63 & 38.37 & \\
\hline 41.35 & 1.311 & 0.97 & 52.90 & 47.10 & 31 \\
\hline 41.83 & 1.329 & 0.97 & 70.18 & 29.82 & \\
\hline 42.11 & 1.340 & 0.97 & 40.50 & 59.50 & \\
\hline 42.70 & 1.362 & 0.97 & 56.4 & 43.60 & \\
\hline 42.85 & 1.368 & 0.97 & 42.70 & 57.30 & 44 \\
\hline 43.02 & 1.375 & 0.94 & 82.30 & 17.30 & \\
\hline 43.33 & 1.386 & 0.87 & 52.59 & 47.41 & \\
\hline 43.61 & 1.396 & 0.81 & 69.50 & 30.50 & \\
\hline 44.20 & 1.418 & 0.89 & 81.6 & 18.40 & \\
\hline 44.33 & 1.423 & 0.92 & 68.83 & 31.17 & \\
\hline
\end{tabular}

Appendix C (continued).

\begin{tabular}{|c|c|c|c|c|c|}
\hline $\begin{array}{l}\text { Composite } \\
\text { depth (m) }\end{array}$ & $\begin{array}{c}\text { Age } \\
\text { (m.y.) }\end{array}$ & $\begin{array}{c}\text { Dry-bulk } \\
\text { density } \\
\left(\mathrm{g} / \mathrm{cm}^{3}\right)\end{array}$ & $\begin{array}{c}\mathrm{CaCO}_{3} \\
(\%)\end{array}$ & $\begin{array}{c}\text { Siliciclastic } \\
(\%)\end{array}$ & $\begin{array}{c}\text { Quartz } \\
(\%)\end{array}$ \\
\hline 44.35 & 1.424 & 0.66 & 83.40 & 16.60 & 4 \\
\hline 44.73 & 1.438 & 0.92 & 42.27 & 57.73 & \\
\hline 44.83 & 1.442 & 0.75 & 60.24 & 39.76 & \\
\hline 45.11 & 1.452 & 0.81 & 49.00 & 51.00 & \\
\hline 45.70 & 1.474 & 0.93 & 54.1 & 45.90 & \\
\hline 45.85 & 1.480 & 0.96 & 59.40 & 40.60 & 26 \\
\hline 46.15 & 1.491 & 0.97 & 81.37 & 18.63 & \\
\hline 46.21 & 1.493 & 0.98 & 80.30 & 19.70 & \\
\hline 47.23 & 1.532 & 0.91 & 63.24 & 36.76 & \\
\hline 47.70 & 1.549 & 0.94 & 43.80 & 56.2 & \\
\hline 48.21 & 1.568 & 0.97 & 77.00 & 23.00 & \\
\hline 48.63 & 1.584 & 0.77 & 68.83 & 31.17 & \\
\hline 48.70 & 1.587 & 0.74 & 59.54 & 40.46 & \\
\hline 50.21 & 1.643 & 0.64 & 72.90 & 27.10 & \\
\hline 50.35 & 1.649 & 0.62 & 60.20 & 39.80 & \\
\hline 50.73 & 1.663 & 0.64 & 42.27 & 57.73 & \\
\hline 51.20 & 1.681 & 0.66 & 40.15 & 59.85 & \\
\hline 51.70 & 1.699 & 0.68 & 57.76 & 42.24 & \\
\hline 51.85 & 1.705 & 0.68 & 54.80 & 45.20 & \\
\hline 52.23 & 1.719 & 0.69 & 63.24 & 36.76 & \\
\hline 53.21 & 1.756 & 0.75 & 61.10 & 38.90 & \\
\hline 53.35 & 1.761 & 0.77 & 55.70 & 44.30 & \\
\hline 53.73 & 1.775 & 0.77 & 66.77 & 33.23 & \\
\hline 54.20 & 1.793 & 0.77 & 67.98 & 32.02 & \\
\hline 54.71 & 1.812 & 0.77 & 48.60 & 51.40 & \\
\hline 54.85 & 1.817 & 0.76 & 67.90 & 32.10 & \\
\hline 55.23 & 1.831 & 0.77 & 55.20 & 44.80 & \\
\hline 55.67 & 1.848 & 0.77 & 76.52 & 23.48 & \\
\hline 56.21 & 1.868 & 0.77 & 84.50 & 15.50 & \\
\hline 56.35 & 1.873 & 0.81 & 77.00 & 23.00 & \\
\hline 56.73 & 1.887 & 0.82 & 45.69 & 54.31 & \\
\hline 57.20 & 1.904 & 0.96 & 66.6 & 33.40 & \\
\hline 57.35 & 1.909 & 1.00 & 59.90 & 40.10 & 25 \\
\hline 57.71 & 1.921 & 0.99 & 80.00 & 20.00 & \\
\hline 57.83 & 1.925 & 0.99 & 43.56 & 56.44 & \\
\hline 57.85 & 1.926 & 0.84 & 66.20 & 33.80 & \\
\hline 58.11 & 1.935 & 0.98 & 74.20 & 25.80 & \\
\hline 58.23 & 1.939 & 0.87 & 48.74 & 51.26 & \\
\hline 58.70 & 1.956 & 0.94 & 76.43 & 23.57 & \\
\hline 58.83 & 1.960 & 0.97 & 85.40 & 14.60 & 5 \\
\hline 59.31 & 1.976 & 0.98 & 75.39 & 24.61 & \\
\hline 59.59 & 1.986 & 0.99 & 62.00 & 38.00 & \\
\hline 59.91 & 1.997 & 0.99 & 74.40 & 25.60 & \\
\hline 60.20 & 2.007 & 1.02 & 75.4 & 24.60 & \\
\hline 60.71 & 2.024 & 1.06 & 53.52 & 46.48 & \\
\hline 60.81 & 2.028 & 1.00 & 66.32 & 33.68 & \\
\hline 61.09 & 2.037 & 1.01 & 60.70 & 39.30 & \\
\hline 61.42 & 2.049 & 1.02 & 83.72 & 16.28 & \\
\hline 61.83 & 2.063 & 1.03 & 63.00 & 37.00 & 28 \\
\hline 62.21 & 2.075 & 1.06 & 52.24 & 47.76 & \\
\hline 62.31 & 2.077 & 1.04 & 57.03 & 42.97 & \\
\hline 62.59 & 2.085 & 1.05 & 65.60 & 34.40 & \\
\hline 63.33 & 2.106 & 1.07 & 53.10 & 46.90 & 30 \\
\hline 63.71 & 2.116 & 1.13 & 48.81 & 51.19 & \\
\hline 63.81 & 2.119 & 1.08 & 68.32 & 31.68 & \\
\hline 64.09 & 2.127 & 1.09 & 51.70 & 48.30 & \\
\hline 64.71 & 2.144 & 1.08 & 56.73 & 43.27 & \\
\hline 64.83 & 2.148 & 1.10 & 42.00 & 58.00 & 40 \\
\hline 65.31 & 2.161 & 1.07 & 80.76 & 19.24 & \\
\hline 65.59 & 2.169 & 1.05 & 81.30 & 18.70 & \\
\hline 66.00 & 2.180 & 1.02 & 66.6 & 33.40 & \\
\hline 66.11 & 2.184 & 1.01 & 62.11 & 37.89 & \\
\hline 66.17 & 2.185 & 1.01 & 51.10 & 48.90 & \\
\hline 66.21 & 2.186 & 0.97 & 75.78 & 24.22 & \\
\hline 66.88 & 2.206 & 0.89 & 79.30 & 20.70 & \\
\hline 66.96 & 2.209 & 0.91 & 80.3 & 19.70 & \\
\hline 67.33 & 2.221 & 1.00 & 43.92 & 56.08 & \\
\hline 67.41 & 2.223 & 0.90 & 67.67 & 32.33 & \\
\hline 67.46 & 2.225 & 0.91 & 69.80 & 30.20 & \\
\hline 67.94 & 2.241 & 0.92 & 76.26 & 23.74 & \\
\hline 68.07 & 2.245 & 0.92 & 81.50 & 18.50 & 4 \\
\hline 68.21 & 2.249 & 1.01 & 79.64 & 20.36 & \\
\hline 68.55 & 2.261 & 0.93 & 81.89 & 18.11 & \\
\hline 68.68 & 2.265 & 0.94 & 60.90 & 39.10 & \\
\hline 69.14 & 2.280 & 0.92 & 83.7 & 16.30 & \\
\hline 69.57 & 2.294 & 0.95 & 56.50 & 43.50 & 28 \\
\hline
\end{tabular}


Appendix C (continued).

\begin{tabular}{|c|c|c|c|c|c|}
\hline $\begin{array}{l}\text { Composite } \\
\text { depth (m) }\end{array}$ & $\begin{array}{c}\text { Age } \\
\text { (m.y.) }\end{array}$ & $\begin{array}{c}\text { Dry-bulk } \\
\text { density } \\
\left(\mathrm{g} / \mathrm{cm}^{3}\right)\end{array}$ & $\begin{array}{c}\mathrm{CaCO}_{3} \\
(\%)\end{array}$ & $\begin{array}{c}\text { Siliciclastic } \\
(\%)\end{array}$ & $\begin{array}{c}\text { Quartz } \\
(\%)\end{array}$ \\
\hline 69.71 & 2.299 & 0.94 & 80.14 & 19.86 & \\
\hline 70.05 & 2.310 & 0.94 & 48.50 & 51.50 & \\
\hline 70.18 & 2.314 & 0.94 & 46.70 & 53.30 & \\
\hline 70.64 & 2.329 & 0.95 & 77.8 & 22.20 & \\
\hline 71.07 & 2.343 & 0.93 & 53.00 & 47.00 & 30 \\
\hline 71.21 & 2.348 & 0.91 & 73.50 & 26.50 & \\
\hline 71.55 & 2.359 & 0.95 & 79.74 & 20.26 & \\
\hline 71.68 & 2.363 & 0.96 & 81.20 & 18.80 & \\
\hline 72.57 & 2.392 & 0.98 & 61.10 & 38.90 & 10 \\
\hline 72.71 & 2.397 & 0.99 & 59.58 & 40.42 & \\
\hline 73.05 & 2.407 & 0.98 & 80.14 & 19.86 & \\
\hline 73.18 & 2.411 & 0.99 & 75.30 & 24.70 & \\
\hline 73.64 & 2.426 & 0.93 & 84.5 & 15.50 & \\
\hline 74.07 & 2.440 & 0.99 & 66.90 & 33.10 & 19 \\
\hline 74.21 & 2.444 & 1.07 & 55.71 & 44.29 & \\
\hline 74.28 & 2.446 & 0.98 & 60.29 & 39.71 & \\
\hline 74.33 & 2.448 & 0.98 & 71.60 & 28.40 & \\
\hline 76.20 & 2.507 & 0.99 & 83.2 & 16.80 & \\
\hline 76.35 & 2.511 & 0.91 & 83.10 & 16.90 & \\
\hline 76.82 & 2.526 & 0.92 & 77.55 & 22.45 & \\
\hline 77.11 & 2.535 & 0.92 & 73.50 & 26.50 & \\
\hline 77.73 & 2.555 & 0.97 & 42.62 & 57.38 & \\
\hline 78.14 & 2.568 & 0.94 & 70.40 & 29.60 & 13 \\
\hline 78.32 & 2.573 & 0.94 & 63.88 & 36.12 & \\
\hline 78.61 & 2.583 & 1.00 & 71.30 & 28.70 & \\
\hline 79.23 & 2.602 & 0.93 & 82.18 & 17.82 & \\
\hline 79.35 & 2.606 & 1.13 & 56.40 & 43.60 & 28 \\
\hline 79.82 & 2.621 & 1.06 & 73.78 & 26.22 & \\
\hline 80.11 & 2.630 & 0.92 & 80.94 & 19.06 & \\
\hline 80.11 & 2.630 & 1.01 & 76.20 & 23.80 & \\
\hline 80.85 & 2.653 & 0.90 & 83.80 & 16.20 & 4 \\
\hline 81.32 & 2.668 & 0.92 & 80.73 & 19.27 & \\
\hline 81.61 & 2.677 & 0.93 & 78.40 & 21.60 & \\
\hline 81.94 & 2.687 & 0.94 & 76.94 & 23.06 & \\
\hline 82.35 & 2.700 & 0.95 & 82.50 & 17.50 & 3 \\
\hline 82.81 & 2.715 & 0.97 & 76.90 & 23.10 & \\
\hline 82.82 & 2.715 & 0.97 & 76.70 & 23.30 & \\
\hline 83.11 & 2.724 & 0.99 & 87.40 & 12.60 & \\
\hline 83.81 & 2.746 & 1.02 & 74.80 & 25.20 & \\
\hline 83.85 & 2.747 & 1.02 & 69.40 & 30.60 & 13 \\
\hline 83.91 & 2.749 & 0.98 & 56.14 & 43.86 & \\
\hline 84.24 & 2.760 & 0.96 & 48.68 & 51.32 & \\
\hline 85.70 & 2.805 & 0.91 & 84.4 & 15.60 & \\
\hline 85.85 & 2.810 & 0.95 & 75.10 & 24.90 & 8 \\
\hline 86.21 & 2.822 & 0.97 & 65.77 & 34.23 & \\
\hline 86.71 & 2.837 & 1.00 & 66.20 & 33.80 & \\
\hline 87.17 & 2.852 & 1.03 & 81.5 & 18.50 & \\
\hline 87.26 & 2.855 & 1.03 & 75.11 & 24.89 & \\
\hline 87.32 & 2.856 & 1.03 & 62.10 & 37.90 & 25 \\
\hline 87.58 & 2.865 & 1.01 & 63.42 & 36.58 & \\
\hline 87.96 & 2.877 & 0.98 & 79.85 & 20.15 & \\
\hline 88.18 & 2.883 & 0.95 & 62.30 & 37.70 & \\
\hline 88.82 & 2.904 & 0.90 & 82.50 & 17.50 & 5 \\
\hline 89.13 & 2.913 & 0.94 & 73.6 & 26.40 & \\
\hline 89.18 & 2.915 & 0.94 & 80.79 & 19.21 & \\
\hline 89.28 & 2.918 & 0.95 & 66.54 & 33.46 & \\
\hline 89.31 & 2.919 & 0.95 & 85.19 & 14.81 & \\
\hline 89.38 & 2.921 & 0.96 & 78.65 & 21.35 & \\
\hline 89.47 & 2.924 & 0.98 & 78.2 & 21.80 & \\
\hline 89.68 & 2.931 & 1.00 & 46.80 & 53.20 & \\
\hline 90.17 & 2.946 & 1.06 & 77.9 & 22.10 & \\
\hline 90.32 & 2.951 & 1.07 & 57.40 & 42.60 & 31 \\
\hline 90.68 & 2.962 & 1.03 & 79.57 & 20.43 & \\
\hline 90.76 & 2.965 & 1.01 & 59.81 & 40.19 & \\
\hline 91.18 & 2.978 & 0.98 & 81.50 & 18.50 & \\
\hline 91.82 & 2.998 & 0.92 & 82.30 & 17.70 & 3 \\
\hline 92.18 & 3.009 & 0.95 & 82.27 & 17.73 & \\
\hline 92.26 & 3.012 & 0.91 & 74.60 & 25.40 & \\
\hline 92.68 & 3.025 & 1.00 & 51.80 & 48.20 & \\
\hline 93.32 & 3.046 & 1.06 & 63.00 & 37.00 & 17 \\
\hline 93.68 & 3.057 & 1.05 & 84.26 & 15.74 & \\
\hline 93.76 & 3.059 & 0.90 & 81.78 & 18.22 & \\
\hline 95.26 & 3.107 & 0.99 & 72.76 & 27.24 & \\
\hline 95.35 & 3.110 & 1.00 & 66.20 & 33.80 & 17 \\
\hline 95.71 & 3.121 & 1.01 & 84.19 & 15.81 & \\
\hline 95.73 & 3.122 & 1.01 & 86.59 & 13.41 & \\
\hline
\end{tabular}

Appendix C (continued).

\begin{tabular}{|c|c|c|c|c|c|}
\hline $\begin{array}{l}\text { Composite } \\
\text { depth (m) }\end{array}$ & $\begin{array}{c}\text { Age } \\
\text { (m.y.) }\end{array}$ & $\begin{array}{c}\text { Dry-bulk } \\
\text { density } \\
\left(\mathrm{g} / \mathrm{cm}^{3}\right)\end{array}$ & $\begin{array}{c}\mathrm{CaCO}_{3} \\
(\%)\end{array}$ & $\begin{array}{l}\text { Siliciclastic } \\
(\%)\end{array}$ & $\begin{array}{c}\text { Quartz } \\
(\%)\end{array}$ \\
\hline 96.21 & 3.137 & 1.02 & 69.20 & 30.80 & \\
\hline 96.62 & 3.150 & 0.99 & 71.2 & 28.80 & \\
\hline 96.76 & 3.154 & 0.99 & 60.78 & 39.22 & \\
\hline 96.77 & 3.155 & 1.03 & 59.80 & 40.20 & 13 \\
\hline 97.15 & 3.167 & 1.01 & 45.18 & 54.82 & \\
\hline 97.63 & 3.182 & 0.98 & 75.50 & 24.50 & \\
\hline 98.05 & 3.195 & 0.98 & 67.81 & 32.19 & \\
\hline 98.25 & 3.201 & 0.94 & 81.90 & 18.10 & 4 \\
\hline 98.63 & 3.213 & 0.94 & 84.15 & 15.85 & \\
\hline 98.99 & 3.225 & 0.94 & 88.40 & 11.60 & \\
\hline 99.40 & 3.238 & 0.94 & 71.1 & 28.90 & \\
\hline 99.55 & 3.242 & 0.94 & 85.90 & 14.10 & \\
\hline 99.91 & 3.254 & 0.95 & 85.80 & 14.20 & \\
\hline 99.93 & 3.254 & 0.95 & 52.70 & 47.30 & \\
\hline 100.26 & 3.265 & 1.12 & 56.34 & 43.66 & \\
\hline 100.32 & 3.267 & 1.12 & 71.60 & 28.40 & \\
\hline 100.41 & 3.270 & 0.96 & 56.70 & 43.30 & \\
\hline 100.56 & 3.274 & 1.07 & 82.54 & 17.46 & \\
\hline 101.00 & 3.288 & 0.97 & 79.3 & 20.70 & \\
\hline 101.15 & 3.293 & 0.96 & 78.90 & 21.10 & 4 \\
\hline 101.41 & 3.301 & 0.98 & 72.50 & 27.50 & \\
\hline 101.46 & 3.303 & 0.94 & 75.47 & 24.53 & \\
\hline 101.50 & 3.304 & 0.94 & 78.70 & 21.30 & \\
\hline 101.52 & 3.305 & 0.98 & 78.53 & 21.47 & \\
\hline 101.76 & 3.312 & 0.93 & 86.26 & 13.74 & \\
\hline 101.91 & 3.317 & 1.01 & 42.50 & 57.50 & \\
\hline 102.56 & 3.338 & 0.96 & 57.10 & 42.90 & \\
\hline 102.86 & 3.347 & 0.92 & 75.53 & 24.47 & \\
\hline 102.92 & 3.349 & 0.92 & 69.00 & 31.00 & \\
\hline 103.16 & 3.357 & 0.94 & 79.81 & 20.19 & \\
\hline 104.01 & 3.383 & 1.00 & 76.50 & 23.50 & \\
\hline 104.30 & 3.393 & 1.02 & 73.00 & 27.00 & \\
\hline 104.40 & 3.396 & 1.02 & 63.85 & 36.15 & \\
\hline 104.46 & 3.398 & 1.06 & 50.80 & 49.20 & \\
\hline 104.55 & 3.400 & 1.11 & 33.70 & 66.30 & \\
\hline 104.60 & 3.402 & 1.14 & 82.6 & 17.40 & \\
\hline 104.65 & 3.404 & 1.17 & 79.70 & 20.30 & \\
\hline 104.66 & 3.404 & 1.17 & 69.70 & 30.30 & \\
\hline 105.01 & 3.415 & 1.15 & 43.20 & 56.80 & \\
\hline 105.41 & 3.428 & 1.12 & 58.30 & 41.70 & \\
\hline 105.51 & 3.431 & 1.08 & 35.70 & 64.30 & \\
\hline 105.80 & 3.440 & 0.95 & 82.60 & 17.40 & \\
\hline 105.86 & 3.442 & 0.96 & 81.19 & 18.81 & \\
\hline 106.16 & 3.451 & 1.00 & 71.70 & 28.30 & \\
\hline 107.05 & 3.479 & 1.11 & 77.80 & 22.20 & \\
\hline 107.30 & 3.487 & 1.14 & 49.20 & 50.80 & \\
\hline 107.36 & 3.489 & 1.13 & 39.63 & 60.37 & \\
\hline 107.42 & 3.491 & 1.13 & 56.60 & 43.40 & \\
\hline 107.66 & 3.499 & 1.11 & 70.08 & 29.92 & \\
\hline 109.06 & 3.543 & 1.09 & 68.50 & 31.50 & \\
\hline 109.16 & 3.546 & 1.09 & 43.00 & 57.00 & \\
\hline 109.30 & 3.551 & 1.09 & 54.90 & 45.10 & \\
\hline 109.67 & 3.562 & 1.04 & 69.72 & 30.28 & \\
\hline 110.80 & 3.599 & 0.89 & 84.10 & 15.90 & \\
\hline 110.86 & 3.601 & 0.89 & 80.69 & 19.31 & \\
\hline 111.17 & 3.612 & 0.91 & 64.02 & 35.98 & \\
\hline 111.31 & 3.616 & 0.91 & 70.80 & 29.20 & \\
\hline 112.30 & 3.649 & 0.95 & 78.30 & 21.70 & \\
\hline 112.36 & 3.651 & 0.95 & 82.12 & 17.88 & \\
\hline 112.61 & 3.659 & 0.95 & 80.90 & 19.10 & \\
\hline 114.11 & 3.708 & 0.96 & 49.70 & 50.30 & \\
\hline 114.45 & 3.719 & 0.97 & 82.50 & 17.50 & 4 \\
\hline 114.81 & 3.731 & 0.99 & 79.29 & 20.71 & \\
\hline 115.31 & 3.748 & 1.00 & 72.60 & 27.40 & \\
\hline 115.91 & 3.767 & 1.02 & 85.10 & 14.90 & \\
\hline 115.95 & 3.769 & 1.02 & 80.60 & 19.40 & 7 \\
\hline 116.31 & 3.781 & 1.02 & 81.08 & 18.92 & \\
\hline 116.81 & 3.797 & 1.01 & 58.00 & 42.00 & \\
\hline 117.30 & 3.813 & 1.00 & 76.2 & 23.80 & \\
\hline 117.45 & 3.818 & 1.00 & 75.70 & 24.30 & 21 \\
\hline 117.81 & 3.830 & 1.01 & 86.04 & 13.96 & \\
\hline 118.31 & 3.846 & 1.02 & 73.60 & 26.40 & \\
\hline 118.61 & 3.856 & 1.03 & 53.40 & 46.60 & \\
\hline 118.95 & 3.867 & 1.03 & 79.20 & 20.80 & 11 \\
\hline 119.31 & 3.879 & 1.01 & 84.07 & 15.93 & \\
\hline 119.81 & 3.896 & 1.00 & 61.50 & 38.50 & \\
\hline
\end{tabular}


Appendix C (continued).

\begin{tabular}{|c|c|c|c|c|c|}
\hline $\begin{array}{l}\text { Composite } \\
\text { depth }(m)\end{array}$ & $\begin{array}{c}\text { Age } \\
\text { (m.y.) }\end{array}$ & $\begin{array}{c}\text { Dry-bulk } \\
\text { density } \\
\left(\mathrm{g} / \mathrm{cm}^{3}\right)\end{array}$ & $\begin{array}{c}\mathrm{CaCO}_{3} \\
(\%)\end{array}$ & $\begin{array}{c}\text { Siliciclastic } \\
(\%)\end{array}$ & $\begin{array}{c}\text { Quartz } \\
(\%)\end{array}$ \\
\hline 120.30 & 3.912 & 0.98 & 86.7 & 13.30 & \\
\hline 120.45 & 3.917 & 0.98 & 85.30 & 14.70 & 5 \\
\hline 120.56 & 3.920 & 0.97 & 71.90 & 28.10 & \\
\hline 120.81 & 3.928 & 1.03 & 51.56 & 48.44 & \\
\hline 121.31 & 3.945 & 1.11 & 75.50 & 24.50 & \\
\hline 121.65 & 3.956 & 1.16 & 59.3 & 40.70 & \\
\hline 121.78 & 3.960 & 1.17 & 48.70 & 51.30 & 38 \\
\hline 122.02 & 3.968 & 1.14 & 83.50 & 16.50 & \\
\hline 122.16 & 3.973 & 0.98 & 82.01 & 17.99 & \\
\hline 122.52 & 3.985 & 1.11 & 60.50 & 39.50 & \\
\hline 123.07 & 4.003 & 1.01 & 65 & 35.00 & \\
\hline 123.56 & 4.019 & 0.93 & 80.65 & 19.35 & \\
\hline 123.80 & 4.027 & 0.98 & 85.8 & 14.20 & \\
\hline 123.95 & 4.032 & 1.01 & 84.30 & 15.70 & 5 \\
\hline 124.33 & 4.044 & 1.01 & 81.92 & 18.08 & \\
\hline 124.71 & 4.056 & 1.00 & 86.90 & 13.10 & \\
\hline 125.06 & 4.068 & 0.93 & 85.96 & 14.04 & \\
\hline 125.45 & 4.081 & 0.99 & 85.60 & 14.40 & 5 \\
\hline 125.83 & 4.093 & 0.99 & 83.11 & 16.89 & \\
\hline 126.01 & 4.099 & 1.03 & 73.03 & 26.97 & \\
\hline 126.21 & 4.106 & 0.99 & 73.10 & 26.90 & \\
\hline 126.72 & 4.123 & 0.99 & 76.6 & 23.40 & \\
\hline 126.95 & 4.130 & 0.99 & 82.90 & 17.10 & 3 \\
\hline 127.33 & 4.143 & 1.01 & 72.29 & 27.71 & \\
\hline 127.51 & 4.149 & 1.12 & 62.27 & 37.73 & \\
\hline 127.71 & 4.155 & 1.05 & 69.10 & 30.90 & \\
\hline 128.30 & 4.175 & 1.10 & 88.3 & 11.70 & \\
\hline 128.45 & 4.179 & 1.11 & 81.20 & 18.80 & 7 \\
\hline 128.83 & 4.192 & 1.09 & 87.21 & 12.79 & \\
\hline 129.21 & 4.204 & 1.07 & 56.90 & 43.10 & \\
\hline 129.80 & 4.224 & 1.11 & 81.2 & 18.80 & \\
\hline 129.81 & 4.224 & 1.11 & 59.87 & 40.13 & \\
\hline 129.95 & 4.229 & 1.04 & 78.10 & 21.90 & 6 \\
\hline 130.33 & 4.241 & 1.05 & 75.15 & 24.85 & \\
\hline 130.71 & 4.254 & 1.06 & 50.50 & 49.50 & \\
\hline 131.61 & 4.283 & 1.16 & 61.55 & 38.45 & \\
\hline 133.11 & 4.333 & 1.05 & 82.11 & 17.89 & \\
\hline 133.45 & 4.344 & 1.10 & 86.30 & 13.70 & 4 \\
\hline 133.83 & 4.356 & 1.10 & 88.45 & 11.55 & \\
\hline 134.31 & 4.372 & 1.09 & 77.30 & 22.70 & \\
\hline 134.61 & 4.382 & 1.03 & 78.62 & 21.38 & \\
\hline 134.80 & 4.388 & 1.07 & 87 & 13.00 & \\
\hline 134.91 & 4.392 & 1.09 & 83.10 & 16.90 & \\
\hline 135.29 & 4.404 & 1.08 & 86.76 & 13.24 & \\
\hline 135.77 & 4.420 & 1.07 & 86.00 & 14.00 & \\
\hline 136.11 & 4.431 & 1.02 & 82.11 & 17.89 & \\
\hline 136.37 & 4.440 & 1.06 & 90.10 & 9.90 & 2 \\
\hline 136.75 & 4.452 & 1.07 & 70.33 & 29.67 & \\
\hline 137.23 & 4.468 & 1.08 & 69.90 & 30.10 & \\
\hline 137.87 & 4.489 & 1.09 & 80.40 & 19.60 & 8 \\
\hline 138.11 & 4.497 & 1.03 & 68.84 & 31.16 & \\
\hline 138.25 & 4.501 & 1.08 & 79.96 & 20.04 & \\
\hline 138.73 & 4.517 & 1.07 & 82.70 & 17.30 & \\
\hline 139.37 & 4.538 & 1.05 & 85.00 & 15.00 & 5 \\
\hline 139.61 & 4.546 & 1.05 & 78.95 & 21.05 & \\
\hline 139.75 & 4.551 & 1.05 & 59.77 & 40.23 & \\
\hline 141.11 & 4.595 & 1.06 & 81.99 & 18.01 & \\
\hline 142.99 & 4.769 & 1.07 & 82.40 & 17.60 & 5 \\
\hline 143.33 & 4.802 & 1.10 & 45.47 & 54.53 & \\
\hline 143.81 & 4.848 & 1.14 & 68.90 & 31.10 & \\
\hline 143.81 & 4.848 & 1.08 & 79.74 & 20.26 & \\
\hline 144.45 & 4.911 & 1.20 & 58.60 & 41.40 & 26 \\
\hline 144.81 & 4.946 & 1.15 & 48.26 & 51.74 & \\
\hline 145.31 & 4.994 & 1.08 & 83.00 & 17.00 & \\
\hline 145.31 & 4.994 & 1.01 & 76.36 & 23.64 & \\
\hline 145.95 & 5.056 & 1.00 & 82.20 & 17.80 & 4 \\
\hline 146.33 & 5.093 & 1.02 & 78.34 & 21.66 & \\
\hline 146.81 & 5.140 & 1.04 & 66.10 & 33.90 & \\
\hline 146.81 & 5.140 & 1.02 & 84.31 & 15.69 & \\
\hline 147.45 & 5.202 & 1.07 & 84.00 & 16.00 & 3 \\
\hline 147.83 & 5.239 & 1.07 & 83.18 & 16.82 & \\
\hline 148.31 & 5.285 & 1.07 & 80.50 & 19.50 & \\
\hline 148.80 & 5.333 & 1.07 & 74.1 & 25.90 & \\
\hline 148.95 & 5.348 & 1.07 & 78.00 & 22.00 & 6 \\
\hline 149.21 & 5.373 & 1.30 & 79.11 & 20.89 & \\
\hline 149.33 & 5.385 & 1.07 & 77.92 & 22.08 & \\
\hline
\end{tabular}

Appendix C (continued).

\begin{tabular}{|c|c|c|c|c|c|}
\hline $\begin{array}{l}\text { Composite } \\
\text { depth (m) }\end{array}$ & $\begin{array}{c}\text { Age } \\
\text { (m.y.) }\end{array}$ & $\begin{array}{c}\text { Dry-bulk } \\
\text { density } \\
\left(\mathrm{g} / \mathrm{cm}^{3}\right)\end{array}$ & $\begin{array}{c}\mathrm{CaCO}_{3} \\
(\%)\end{array}$ & $\begin{array}{c}\text { Siliciclastic } \\
(\%)\end{array}$ & $\begin{array}{c}\text { Quartz } \\
(\%)\end{array}$ \\
\hline 149.81 & 5.431 & 1.08 & 85.80 & 14.20 & \\
\hline 150.71 & 5.518 & 1.09 & 64.91 & 35.09 & \\
\hline 152.21 & 5.651 & 1.10 & 64.76 & 35.24 & \\
\hline 152.45 & 5.669 & 1.11 & 70.00 & 30.00 & 12 \\
\hline 152.83 & 5.699 & 1.10 & 39.77 & 60.23 & \\
\hline 152.86 & 5.701 & 1.10 & 36.10 & 63.90 & 51 \\
\hline 153.21 & 5.728 & 1.09 & 91.80 & 8.20 & \\
\hline 153.66 & 5.763 & 1.08 & 58.40 & 41.60 & 18 \\
\hline 153.82 & 5.775 & 1.07 & 77.60 & 22.40 & 6 \\
\hline 153.96 & 5.786 & 1.08 & 80.16 & 19.84 & \\
\hline 154.16 & 5.801 & 1.06 & 89.10 & 10.90 & 2 \\
\hline 154.20 & 5.804 & 1.06 & 88.09 & 11.91 & \\
\hline 154.68 & 5.841 & 1.06 & 50.80 & 49.20 & \\
\hline 155.13 & 5.876 & 1.06 & 72.80 & 27.20 & 10 \\
\hline 155.17 & 5.879 & 1.07 & 82.8 & 17.20 & \\
\hline 155.26 & 5.886 & 1.16 & 76.58 & 23.42 & \\
\hline 155.27 & 5.887 & 1.05 & 86.80 & 13.20 & 3 \\
\hline 155.65 & 5.916 & 1.05 & 87.26 & 12.74 & \\
\hline 156.13 & 5.953 & 1.06 & 89.50 & 10.50 & \\
\hline 156.46 & 5.978 & 1.11 & 80.02 & 19.98 & \\
\hline 156.63 & 5.991 & 1.08 & 88.4 & 11.60 & \\
\hline 156.77 & 6.002 & 1.06 & 83.60 & 16.40 & 4 \\
\hline 157.15 & 6.031 & 1.10 & 81.66 & 18.34 & \\
\hline 157.63 & 6.068 & 1.15 & 88.50 & 11.50 & \\
\hline 158.27 & 6.118 & 1.21 & 59.00 & 41.00 & 34 \\
\hline 158.36 & 6.125 & 1.21 & 54.70 & 45.30 & 34 \\
\hline 158.65 & 6.147 & 1.21 & 75.35 & 24.65 & \\
\hline 158.78 & 6.157 & 1.05 & 71.58 & 28.42 & \\
\hline 159.13 & 6.184 & 1.21 & 84.50 & 15.50 & \\
\hline 160.05 & 6.255 & 1.05 & 83.10 & 16.90 & \\
\hline 160.51 & 6.290 & 1.07 & 70.07 & 29.93 & \\
\hline 161.55 & 6.370 & 1.14 & 66.60 & 33.40 & \\
\hline 162.01 & 6.406 & 1.13 & 63.58 & 36.42 & \\
\hline 163.05 & 6.486 & 1.10 & 78.40 & 21.60 & \\
\hline 163.51 & 6.521 & 1.13 & 68.28 & 31.72 & \\
\hline 164.55 & 6.601 & 1.20 & 65.30 & 34.70 & \\
\hline 165.01 & 6.637 & 1.17 & 76.87 & 23.13 & \\
\hline 166.41 & 6.745 & 1.15 & 65.69 & 34.31 & \\
\hline 167.91 & 6.860 & 1.11 & 51.50 & 48.50 & \\
\hline 168.05 & 6.871 & 1.11 & 73.40 & 26.60 & \\
\hline 168.43 & 6.900 & 1.16 & 37.56 & 62.44 & \\
\hline 168.51 & 6.906 & 1.17 & 65.57 & 34.43 & \\
\hline 169.39 & 6.974 & 1.28 & 65.10 & 34.90 & \\
\hline 169.55 & 6.987 & 1.29 & 87.00 & 13.00 & \\
\hline 169.93 & 7.016 & 1.24 & 51.57 & 48.43 & \\
\hline 170.01 & 7.022 & 1.23 & 49.99 & 50.01 & \\
\hline 170.89 & 7.090 & 1.14 & 75.10 & 24.90 & \\
\hline 171.05 & 7.102 & 1.09 & 76.90 & 23.10 & \\
\hline 171.43 & 7.131 & 1.10 & 61.08 & 38.92 & \\
\hline 171.51 & 7.138 & 1.11 & 50.42 & 49.58 & \\
\hline 172.39 & 7.206 & 1.14 & 82.50 & 17.50 & \\
\hline 172.55 & 7.218 & 1.14 & 71.10 & 28.90 & \\
\hline 172.93 & 7.247 & 1.16 & 46.06 & 53.94 & \\
\hline 173.01 & 7.253 & 1.16 & 47.67 & 52.33 & \\
\hline 173.32 & 7.277 & 1.18 & 30.00 & 70.00 & \\
\hline 173.89 & 7.321 & 1.21 & 65.30 & 34.70 & \\
\hline 174.05 & 7.333 & 1.22 & 70.20 & 29.80 & \\
\hline 174.27 & 7.350 & 1.22 & 29.70 & 70.30 & \\
\hline 174.43 & 7.363 & 1.23 & 51.82 & 48.18 & \\
\hline 174.51 & 7.369 & 1.24 & 64.24 & 35.76 & \\
\hline 175.26 & 7.427 & 1.24 & 24.70 & 75.30 & \\
\hline 175.39 & 7.437 & 1.24 & 58.50 & 41.50 & \\
\hline 175.55 & 7.449 & 1.24 & 60.80 & 39.20 & \\
\hline 175.93 & 7.478 & 1.25 & 62.05 & 37.95 & \\
\hline 176.01 & 7.484 & 1.25 & 50.48 & 49.52 & \\
\hline 177.37 & 7.589 & 1.27 & 71.60 & 28.40 & \\
\hline 177.55 & 7.603 & 1.30 & 71.40 & 28.60 & \\
\hline 178.53 & 7.678 & 1.30 & 28.44 & 71.56 & \\
\hline 178.61 & 7.685 & 1.30 & 51.60 & 48.40 & \\
\hline 179.44 & 7.749 & 1.30 & 45.60 & 54.40 & \\
\hline 179.65 & 7.765 & 1.30 & 41.40 & 58.60 & \\
\hline 180.03 & 7.794 & 1.34 & 45.90 & 54.10 & \\
\hline 180.11 & 7.800 & 1.34 & 29.03 & 70.97 & \\
\hline 180.90 & 7.861 & 1.26 & 58.40 & 41.60 & \\
\hline 180.94 & 7.864 & 1.25 & 60.50 & 39.50 & 13 \\
\hline 180.97 & 7.866 & 1.28 & 60.80 & 39.20 & \\
\hline
\end{tabular}


Appendix C (continued).

\begin{tabular}{lccccc}
\hline $\begin{array}{c}\text { Composite } \\
\text { depth }(\mathrm{m})\end{array}$ & $\begin{array}{c}\text { Age } \\
(\mathrm{m} . \mathrm{y} .)\end{array}$ & $\begin{array}{c}\text { Dry-bulk } \\
\text { density } \\
\left(\mathrm{g} / \mathrm{cm}^{3}\right)\end{array}$ & $\begin{array}{c}\mathrm{CaCO}_{3} \\
(\%)\end{array}$ & $\begin{array}{c}\text { Siliciclastic } \\
(\%)\end{array}$ & $\begin{array}{c}\text { Quartz } \\
(\%)\end{array}$ \\
\hline 181.15 & 7.880 & 1.45 & 42.80 & 57.20 & \\
181.33 & 7.894 & 1.24 & 56.02 & 43.98 & \\
181.53 & 7.910 & 1.44 & 52.42 & 47.58 & \\
181.61 & 7.916 & 1.44 & 51.30 & 48.70 & \\
181.81 & 7.931 & 1.23 & 49.60 & 50.40 & \\
181.90 & 7.938 & 1.23 & 48.50 & 51.50 & \\
182.45 & 7.980 & 1.22 & 56.60 & 43.40 & 21 \\
182.47 & 7.982 & 1.24 & 32.20 & 67.80 & \\
182.63 & 7.994 & 1.42 & 38.98 & 61.02 & \\
182.65 & 7.996 & 1.42 & 56.00 & 44.00 & \\
\hline
\end{tabular}

Appendix D . Physical properties, grain sizes, and bulk mineralogy data from Site 660 .

\begin{tabular}{|c|c|c|c|c|c|}
\hline $\begin{array}{l}\text { Composite } \\
\text { depth }(\mathrm{m})\end{array}$ & $\begin{array}{l}\text { Age } \\
\text { (m.y.) }\end{array}$ & $\begin{array}{c}\text { Dry-bulk } \\
\text { density } \\
\left(\mathrm{g} / \mathrm{cm}^{3}\right)\end{array}$ & $\begin{array}{c}\mathrm{CaCO}_{3} \\
(\%)\end{array}$ & $\begin{array}{c}\text { Siliciclastic } \\
(\%)\end{array}$ & $\begin{array}{c}\text { Quartz } \\
(\%)\end{array}$ \\
\hline 2.31 & 0.071 & 0.44 & 0.42 & 99.58 & 92 \\
\hline 2.36 & 0.073 & 0.47 & 2.46 & 97.54 & \\
\hline 3.35 & 0.103 & 0.48 & 5.59 & 94.41 & 34 \\
\hline 3.97 & 0.122 & 0.42 & 1.33 & 98.67 & 98 \\
\hline 4.40 & 0.136 & 0.45 & 1.18 & 98.82 & \\
\hline 5.44 & 0.168 & 0.56 & 10.00 & 90.00 & 34 \\
\hline 5.90 & 0.182 & 0.53 & 36.34 & 63.66 & \\
\hline 7.19 & 0.222 & 0.46 & 25.50 & 74.50 & 13 \\
\hline 7.40 & 0.228 & 0.46 & 11.55 & 88.45 & \\
\hline 8.08 & 0.249 & 0.47 & 27.69 & 72.31 & 14 \\
\hline 8.69 & 0.268 & 0.47 & 2.30 & 97.70 & 50 \\
\hline 8.90 & 0.274 & 0.42 & 5.69 & 94.31 & \\
\hline 10.19 & 0.314 & 0.41 & 0.33 & 99.67 & 39 \\
\hline 10.40 & 0.321 & 0.38 & 0.01 & 99.99 & \\
\hline 11.33 & 0.349 & 0.37 & 48.12 & 51.88 & 12 \\
\hline 11.69 & 0.360 & 0.37 & 0.58 & 99.42 & \\
\hline 11.84 & 0.365 & 0.41 & 0.42 & 99.58 & \\
\hline 11.90 & 0.367 & 0.43 & 0.01 & 99.99 & \\
\hline 13.72 & 0.423 & 0.47 & 21.80 & 78.20 & 15 \\
\hline 13.90 & 0.428 & 0.47 & 34.94 & 65.06 & \\
\hline 15.17 & 0.468 & 0.55 & 0.33 & 99.67 & \\
\hline 15.40 & 0.479 & 0.53 & 2.27 & 97.73 & \\
\hline 16.67 & 0.555 & 0.42 & 10.10 & 89.90 & 32 \\
\hline 16.90 & 0.569 & 0.42 & 0.01 & 99.99 & \\
\hline 17.32 & 0.594 & 0.44 & 0.58 & 99.42 & \\
\hline 17.55 & 0.607 & 0.45 & 3.36 & 96.64 & \\
\hline 18.82 & 0.683 & 0.51 & 0.58 & 99.42 & 88 \\
\hline 19.05 & 0.697 & 0.50 & 24.59 & 75.41 & \\
\hline 20.32 & 0.764 & 0.59 & 0.42 & 99.58 & \\
\hline 20.55 & 0.775 & 0.54 & 21.82 & 78.18 & \\
\hline 22.37 & 0.861 & 0.60 & 36.28 & 63.72 & 15 \\
\hline 22.55 & 0.870 & 0.59 & 0.01 & 99.99 & \\
\hline 23.85 & 0.929 & 0.60 & 0.75 & 99.25 & 78 \\
\hline 24.05 & 0.937 & 0.59 & 30.56 & 69.44 & \\
\hline 25.35 & 0.993 & 0.53 & 7.42 & 92.58 & 23 \\
\hline 25.55 & 1.004 & 0.55 & 0.01 & 99.99 & \\
\hline 27.55 & 1.111 & 0.75 & 45.12 & 54.88 & 12 \\
\hline 27.75 & 1.122 & 0.73 & 36.70 & 63.30 & \\
\hline 29.05 & 1.191 & 0.57 & 21.68 & 78.32 & 21 \\
\hline 29.07 & 1.192 & 0.57 & 2.30 & 97.70 & 4 \\
\hline 29.16 & 1.197 & 0.60 & 2.34 & 97.66 & \\
\hline 29.25 & 1.198 & 0.67 & 0.01 & 99.99 & \\
\hline 30.55 & 1.271 & 0.71 & 30.02 & 69.98 & 16 \\
\hline 30.75 & 1.282 & 0.65 & 46.50 & 53.50 & \\
\hline 32.57 & 1.379 & 0.65 & 38.20 & 61.80 & 14 \\
\hline 32.75 & 1.389 & 0.75 & 5.21 & 94.79 & \\
\hline 34.07 & 1.456 & 0.72 & 27.44 & 72.56 & \\
\hline 34.25 & 1.461 & 0.69 & 43.77 & 56.23 & \\
\hline 37.87 & 1.591 & 0.63 & 67.05 & 32.95 & 4 \\
\hline 38.05 & 1.598 & 0.64 & 36.88 & 63.12 & \\
\hline 38.49 & 1.613 & 0.66 & 45.04 & 54.96 & 19 \\
\hline 38.67 & 1.620 & 0.67 & 0.33 & 99.67 & 7 \\
\hline 38.75 & 1.623 & 0.67 & 28.61 & 71.39 & \\
\hline 39.37 & 1.645 & 0.70 & 53.79 & 46.21 & 11 \\
\hline 39.55 & 1.651 & 0.69 & 51.21 & 48.79 & \\
\hline
\end{tabular}

Appendix D (continued).

\begin{tabular}{|c|c|c|c|c|c|}
\hline $\begin{array}{l}\text { Composite } \\
\text { depth (m) }\end{array}$ & $\begin{array}{c}\text { Age } \\
\text { (m.y.) }\end{array}$ & $\begin{array}{c}\text { Dry-bulk } \\
\text { density } \\
\left(\mathrm{g} / \mathrm{cm}^{3}\right)\end{array}$ & $\underset{(\%)}{\mathrm{CaCO}_{3}}$ & $\begin{array}{c}\text { Siliciclastic } \\
(\%)\end{array}$ & $\begin{array}{c}\text { Quartz } \\
(\%)\end{array}$ \\
\hline 40.87 & 1.772 & 0.73 & 45.12 & 54.88 & 13 \\
\hline 41.05 & 1.791 & 0.72 & 49.87 & 50.13 & \\
\hline 42.37 & 1.904 & 0.77 & 7.34 & 92.66 & 32 \\
\hline 44.32 & 2.003 & 0.72 & 10.43 & 89.57 & 36 \\
\hline 44.55 & 2.014 & 0.67 & 32.20 & 67.80 & \\
\hline 45.82 & 2.078 & 0.79 & 28.36 & 71.64 & 13 \\
\hline 46.05 & 2.090 & 0.73 & 0.01 & 99.99 & \\
\hline 47.32 & 2.152 & 0.80 & 12.93 & 87.07 & 18 \\
\hline 47.75 & 2.173 & 0.75 & 51.30 & 48.70 & \\
\hline 49.02 & 2.241 & 0.70 & 59.46 & 40.54 & 6 \\
\hline 49.25 & 2.254 & 0.71 & 40.46 & 59.54 & \\
\hline 50.52 & 2.326 & 0.81 & 30.52 & 69.48 & 18 \\
\hline 50.75 & 2.339 & 0.75 & 0.01 & 99.99 & \\
\hline 52.02 & 2.411 & 0.73 & 51.62 & 48.38 & 6 \\
\hline 52.25 & 2.425 & 0.73 & 27.00 & 73.00 & \\
\hline 54.07 & 2.557 & 0.75 & 48.69 & 51.31 & 11 \\
\hline 54.25 & 2.572 & 0.74 & 4.45 & 95.55 & \\
\hline 55.57 & 2.684 & 0.86 & 39.87 & 60.13 & 11 \\
\hline 55.79 & 2.703 & 0.75 & 64.83 & 35.17 & \\
\hline 57.07 & 2.811 & 0.75 & 63.47 & 36.53 & 4 \\
\hline 57.25 & 2.827 & 0.80 & 52.32 & 47.68 & \\
\hline 58.37 & 2.924 & 0.86 & 68.47 & 31.53 & 5 \\
\hline 58.55 & 2.955 & 0.85 & 23.37 & 76.63 & \\
\hline 59.42 & 3.035 & 0.89 & 3.09 & 96.91 & \\
\hline 59.87 & 3.065 & 0.92 & 50.54 & 49.46 & 1 \\
\hline 60.06 & 3.077 & 0.86 & 64.28 & 35.72 & \\
\hline 60.70 & 3.108 & 0.87 & 73.73 & 26.27 & \\
\hline 61.37 & 3.139 & 0.93 & 53.63 & 46.37 & 10 \\
\hline 61.50 & 3.145 & 0.86 & 30.86 & 69.14 & \\
\hline 61.51 & 3.146 & 0.85 & 56.11 & 43.89 & \\
\hline 63.37 & 3.252 & 0.91 & 50.12 & 49.88 & 9 \\
\hline 63.55 & 3.264 & 0.92 & 41.28 & 58.72 & \\
\hline 64.84 & 3.347 & 0.98 & 47.79 & 52.21 & 9 \\
\hline 65.05 & 3.360 & 0.97 & 42.27 & 57.73 & \\
\hline 66.36 & 3.444 & 0.93 & 66.64 & 33.36 & 9 \\
\hline 66.55 & 3.456 & 0.95 & 53.50 & 46.50 & \\
\hline 67.16 & 3.496 & 1.03 & 34.94 & 65.06 & 11 \\
\hline 67.35 & 3.508 & 1.01 & 26.79 & 73.21 & \\
\hline 68.57 & 3.586 & 1.01 & 26.44 & 73.56 & 28 \\
\hline 68.75 & 3.598 & 0.99 & 53.44 & 46.56 & \\
\hline 70.07 & 3.683 & 0.92 & 64.80 & 35.20 & 4 \\
\hline 70.27 & 3.696 & 0.92 & 53.92 & 46.08 & \\
\hline 70.80 & 3.730 & 0.92 & 47.37 & 52.63 & \\
\hline 72.06 & 3.811 & 0.93 & 52.46 & 47.54 & 9 \\
\hline 72.25 & 3.823 & 0.91 & 30.18 & 69.82 & \\
\hline 73.56 & 3.921 & 0.96 & 16.10 & 83.90 & 8 \\
\hline 73.75 & 3.958 & 0.96 & 25.34 & 74.66 & \\
\hline 76.06 & 4.401 & 0.99 & 2.17 & 97.83 & 39 \\
\hline 76.25 & 4.437 & 0.99 & 12.57 & 87.43 & \\
\hline 77.56 & 4.759 & 0.99 & 37.78 & 62.22 & 9 \\
\hline 77.75 & 4.824 & 0.99 & 23.61 & 76.39 & \\
\hline 79.06 & 5.276 & 1.03 & & & 0 \\
\hline 79.25 & 5.341 & 1.02 & 26.63 & 73.37 & \\
\hline 80.56 & 5.793 & 1.01 & 30.20 & 69.80 & 20 \\
\hline 80.75 & 5.859 & 1.00 & 0.01 & 99.99 & \\
\hline 81.51 & 6.121 & 0.96 & 0 & 100.00 & \\
\hline 82.56 & 6.483 & 0.95 & 0.08 & 99.92 & \\
\hline 82.75 & 6.548 & 0.95 & 0.01 & 99.99 & \\
\hline 83.01 & 6.638 & 0.94 & 0 & 100.00 & \\
\hline
\end{tabular}

Appendix E . Physical properties, grain sizes, and bulk mineralogy data from Site 661 .

\begin{tabular}{|c|c|c|c|c|c|}
\hline $\begin{array}{l}\text { Composite } \\
\text { depth (m) }\end{array}$ & $\begin{array}{l}\text { Age } \\
\text { (m.y.) }\end{array}$ & $\begin{array}{c}\text { Dry-bulk } \\
\text { density } \\
\left(\mathrm{g} / \mathrm{cm}^{3}\right)\end{array}$ & $\begin{array}{c}\mathrm{CaCO}_{3} \\
(\%)\end{array}$ & $\begin{array}{c}\text { Siliciclastic } \\
(\%)\end{array}$ & $\begin{array}{c}\text { Quartz } \\
(\%)\end{array}$ \\
\hline 1.05 & 0.064 & 0.52 & 11.6 & 88.4 & 39 \\
\hline 2.65 & 0.162 & 0.52 & 11.0 & 89.0 & 43 \\
\hline 5.65 & 0.346 & 0.54 & 21.4 & 78.6 & 35 \\
\hline 7.15 & 0.438 & 0.63 & 42.8 & 57.2 & 23 \\
\hline 8.65 & 0.530 & 0.62 & 51.2 & 48.8 & 11 \\
\hline 10.15 & 0.622 & 0.52 & 24.9 & 75.1 & 36 \\
\hline
\end{tabular}


Appendix E (continued).

\begin{tabular}{cccccr}
\hline $\begin{array}{c}\text { Composite } \\
\text { depth }(\mathrm{m})\end{array}$ & $\begin{array}{c}\text { Age } \\
(\mathrm{m} . \mathrm{y} .)\end{array}$ & $\begin{array}{c}\text { Dry-bulk } \\
\text { density } \\
\left(\mathrm{g} / \mathrm{cm}^{3}\right)\end{array}$ & $\begin{array}{c}\mathrm{CaCO}_{3} \\
(\%)\end{array}$ & $\begin{array}{c}\text { Siliciclastic } \\
(\%)\end{array}$ & $\begin{array}{c}\text { Quartz } \\
(\%)\end{array}$ \\
\hline 12.15 & 0.745 & 0.39 & 5.7 & 94.3 & 23 \\
15.15 & 0.929 & 0.58 & 51.2 & 48.8 & 10 \\
16.65 & 1.020 & 0.69 & 38.3 & 61.7 & 18 \\
18.15 & 1.112 & 0.56 & 56.7 & 43.3 & 12 \\
19.61 & 1.202 & 0.69 & 43.9 & 56.1 & 15 \\
21.63 & 1.326 & 0.68 & 65.1 & 34.9 & 11 \\
23.10 & 1.416 & 0.69 & 37.1 & 62.9 & 17 \\
24.57 & 1.506 & 0.59 & 70.0 & 30.0 & 5 \\
26.04 & 1.596 & 0.66 & 64.6 & 35.4 & 9 \\
27.51 & 1.686 & 0.72 & 48.6 & 51.4 & 14 \\
28.98 & 1.776 & 0.73 & 29.3 & 70.7 & 20 \\
31.16 & 1.915 & 0.74 & 51.7 & 48.3 & 5 \\
32.66 & 2.052 & 0.76 & 55.5 & 44.5 & 9 \\
34.16 & 2.190 & 0.76 & 57.1 & 42.9 & 9 \\
35.66 & 2.327 & 0.70 & 48.7 & 51.3 & 10 \\
37.16 & 2.460 & 0.73 & 71.5 & 28.5 & 6 \\
38.66 & 2.551 & 0.79 & 44.4 & 55.6 & 13 \\
40.65 & 2.672 & 0.74 & 76.0 & 24.0 & 4 \\
42.12 & 2.761 & 0.81 & 61.7 & 38.3 & 8 \\
43.64 & 2.854 & 0.86 & 65.1 & 34.9 & 10 \\
45.14 & 2.945 & 0.80 & 68.3 & 31.7 & 5 \\
46.64 & 3.036 & 0.80 & 79.0 & 21.0 & 3 \\
48.14 & 3.127 & 0.79 & 52.1 & 47.9 & 9
\end{tabular}

Appendix E (continued).

\begin{tabular}{|c|c|c|c|c|c|}
\hline $\begin{array}{l}\text { Composite } \\
\text { depth }(\mathrm{m})\end{array}$ & $\begin{array}{l}\text { Age } \\
\text { (m.y.) }\end{array}$ & $\begin{array}{c}\text { Dry-bulk } \\
\text { density } \\
\left(\mathrm{g} / \mathrm{cm}^{3}\right)\end{array}$ & $\begin{array}{c}\mathrm{CaCO}_{3} \\
(\%)\end{array}$ & $\begin{array}{c}\text { Siliciclastic } \\
(\%)\end{array}$ & $\begin{array}{l}\text { Quartz } \\
(\%)\end{array}$ \\
\hline 50.15 & 3.249 & 0.77 & 72.1 & 27.9 & 5 \\
\hline 51.65 & 3.340 & 0.90 & 65.4 & 34.6 & 9 \\
\hline 53.15 & 3.432 & 0.97 & 59.7 & 40.3 & 5 \\
\hline 54.65 & 3.523 & 0.97 & 53.7 & 46.3 & 10 \\
\hline 56.15 & 3.614 & 0.90 & 68.9 & 31.1 & 10 \\
\hline 57.65 & 3.705 & 0.89 & 71.6 & 28.4 & 4 \\
\hline 59.65 & 3.827 & 0.99 & 44.5 & 55.5 & 11 \\
\hline 61.15 & 3.918 & 0.79 & 52.7 & 47.3 & 9 \\
\hline 62.65 & 4.009 & 0.96 & 63.0 & 37.0 & 8 \\
\hline 64.15 & 4.418 & 0.99 & 35.0 & 65.0 & 13 \\
\hline 65.65 & 4.798 & 0.98 & 45.3 & 54.7 & 8 \\
\hline 67.15 & 5.178 & 0.95 & 69.7 & 30.3 & 5 \\
\hline 69.15 & 5.685 & 1.01 & 50.5 & 49.5 & 8 \\
\hline 72.15 & 6.445 & 1.07 & 26.3 & 73.7 & 13 \\
\hline 73.65 & 6.825 & 0.97 & 0.3 & 99.7 & \\
\hline 75.15 & 7.205 & 0.98 & 0.3 & 99.7 & \\
\hline 76.65 & 7.585 & 0.95 & 0 & 100.0 & \\
\hline 78.65 & 8.091 & 1.09 & 40.8 & 59.2 & 12 \\
\hline 80.15 & 8.471 & 1.01 & 50.2 & 49.8 & 8 \\
\hline 81.65 & 8.851 & 1.04 & 33.9 & 66.1 & 9 \\
\hline 83.15 & 9.231 & 0.98 & 0.3 & 99.7 & \\
\hline 84.65 & 9.611 & 1.09 & 0 & 100.0 & \\
\hline
\end{tabular}

